\title{
Insect Community Structure and Function in Upper Three Runs, Savannah River Site, South Carolina (U)
}

\section{DISCLAIMER}

\begin{abstract}
This report was prepared as an account of work sponsored by an agency of the United States Government. Neither the United States Government nor any agency thereof, nor any of their employees, makes any warranty, express or implied, or assumes any legal liability or responsibility for the accuracy, completeness, or usefulness of any information, apparatus, product, or process disclosed, or represents that its use would not infringe privately owned rights. Reference hrrein to any specific commercial product, process, or service by trade name, trademark, manufacturer, or otherwise does not necessarily constitute or imply its endorsement, recommendation, or favoring by the United States Government or any agency thereof. The views and opinions of authors expressed herein do not necessarily state or reflect those of the United States Government or any agency thereof.
\end{abstract}

Prepared for the U.S. Department of Energy under Contract Numbers DE-AC09-76SR00001 and DE-AC0989SR18035. 


\section{DISCLAIMER}

This report was prepared as an account of work sponsored by an agency of the United States Government. Neither the United States Government nor any agency thereof, nor any of their employees, makes any warranty, express or implied, or assumes any legal liability or responsibility for the accuracy, completeness, or usefulness of any information, apparatus, product, or process disclosed, or represents that its use would not infringe privately owned rights. Reference herein to any specific commercial product, process, or service by trade name, trademark, manufacturer, or otherwise does not necessarily constitute or imply its endorsement, recommendation, or favoring by the United States Government or any agency thereof. The views and opinions of authors expressed herein do not necessarily state or reflect those of the United States Government or any agency thereof.

This report has been reproduced directly from the best available copy.

Available to DOE and DOE contractors from the Office of Scientific and Technical Information, P. O. Box 62, Oak Ridge, TN 37831: prices available from (615) $576-8401$.

Available to the public from the National Technical Information Service, U. S. Department of Commerce, 5285 Port Royal Rd., Springfield, VA 22161 
Insect Community Structure and Function in Upper Three Runs, Savannah River Site, South Carolina (U)

July 8, 1993

J. C. Morse*

W. R. English*

B. B. Looney

Technical Representative:

Brian B. Joony

Approved by:

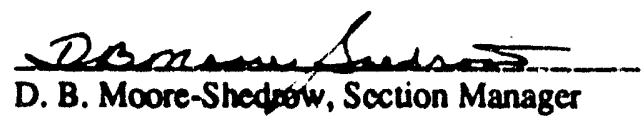

Environmental Sciences Section

Savannah River Technology Center

Westinghouse Savannah River Company

Aiken, SC 29808

- Department of Entomology

Clemson University

Clemson, SC 29634-0365

Prepared for the U.S. Department of Energy under Contract Numbers DE-AC09.76SR00001 and DE-ACO9. 89SR18035. 


\title{
Insect Community Structure and Function in Upper Three Runs, Savannah River Site, South Carolina
}

\author{
Project Summary
}

\begin{abstract}
A project to document the insect species in the upper reaches of Upper Three Runs at the Savannah River Site was recently completed. This research was supported by the U.S. Department of Energy under the National Environmental Research Park Program. The work was performed by the Department of Entomology at Clemson University in Clemson, SC, by John C. Morse (principal investigator), William R. English and their colleagues. The major oupput from this stucty was the dissertation of Dr. William R. English entilled "Ecosystem Dynamics of a South Carolina Sandhills Stream". He investigated selected environmental resources and determined their dystamics and the dymamics of the aquatic invertebrate community structure in response to them.
\end{abstract}


The principal conclusions from the project are as follows:

- There is a strong diel pattern for dissolved oxygen, $\mathrm{pH}$, and temperature in Upper Three Runs, demonstrating the importance of aquatic plants in this system.

- Habitat types-Sandy main channel areas covered most of the creek bottom and accumulated litule organic matter. Aquatic plants altered current velocity and sorted organic matter into detrital pools. Snags were capable of changing the distribution of aquatic plants. Pools were temporary.

- The discharge regime was very stable and predictable by Colwell's Index of Predictability.

- Macro invertebrate density was greatest in the main channel and plant-associated habitats (plant stems and benthic areas within plant beds, and on snag habitats); it was lowest in the main channel and in pool habitats.

- Functional foeding group percentages and particular taxa varied considerably among habitat types. Between-year differences in organism abundance's, taxa richness, diversity, biotic index values, and EPT ratios were not significant Faunas in 1984 and 1985 shared $87 \%$ of their taxa. These data show that community-based indices of water quality may not be representative of the stream if samples are taken only in specified habitats.
Attached is a list of the presentations at scientific meetings, theses and dissertations, publications in scholarly books and refereed professional journals, and manuscripts completed or in preparation resulting entirely or in part upon Clemson University research on the Upper Three Runs Creek macro invertebrate fauna. Those items resulting specifically from this NERP project are noted with an asterisk (*). In addition to the above, several manuscripts are in preparation or have been published which describe about 60 new species and two new genera of aquatic insects captured in these investigations. Other manuscripts are in preparation which provide significant new distribution records for particular species. Specimens of many interesting species are now widely scattered among taxonomic specialists; as a result, the attached does not represent a comprehensive tally of publications and other scientific communications resulting from the base-line research conducted on Upper Three Runs Creek to date.

The identified insect community data on the upper reaches of Upper Three Runs will assist SRS in documenting site environmental protoction efforts and will assist in activities such as facility siting and National Environmental Policy Act documentation. Note that the principal investigators are currently collaborating with researchers at the University of Georgia Savannah River Ecology Lab to sudy the lower reaches of Upper Three Runs. 


\section{List of Publications}


Results Based Entirely or in Part upon Clemson University Research on Upper Three Runs Creek Insect Fauna, Savannah River National Environmental Research Park, Aiken, South Carolina

PRESENTATIONS AT SCIENTIEIC MEETINGS:

Chapin, J. W. 1977. Larvae of the genus Micrasema (Trichoptera: Brachycentridae) in the Southeastern United States. Southeastern Branch of the Entomol. Soc. of America annual meeting, Charleston, South Carolina. 26 January 1977.

Chapin, J. W. and J. C. Morse. 1978. A comparison of benthic faunal surveys based on bottom sampling and light trapping. North American Benthological Society annual meeting in winnipeg, Manitoba, 12 May 1978.

* English, W. R. 1985. Importance of Sparqanium americanum and potamogeton epihydras in structuring aquatic insect communities in streams. Formal Conference on Aquatic lnsect/Plant Interactions (invited speaker), Entomological Society of America annual meeting in Hollywood, Florida, 10 December 1985.

* English, W. R. 1985. Importance of aquatic plants in the macrobenthic community structure of Sand Hilis streams. North American Benthological Society annual meetinq in Corvallis, Oregon, 26 June 1985.

* English, W. R. 1986. Relationships between habitat type and aquatic invertebrate community structure. (invited speaker) Association of Southeastern Biologists annual meeting in Columbia, South Carolina, 10 April 1986.

* English, W. R. 1987. Physical-chemical dynamics of a South Carolina Sandhills stream. North American Benthological Society annual meeting in Orono, Maine. 4 June 1987.

* English, W. R. 1987. Physical-chemical dynamics of a South Carolina Sandhills stream. Carolinas Area Benthic Biologists Annual meeting in New Hill, North Carolina, 5 November 1987.

Herlong, D. D. 1978. Aquatic Lepidoptera in South Carolina. Southeastern Branch of the Entomological Society of America annual meeting in Gainesville, Florida, 25 January 1978.

Herlong, D. D. 1978. Aquatic Lepidoptera (Pyralidae: Nymphulinae) in South Carolina. South Carolina Entomological Society annual meeting in Myrtle Beach. South Carolina, 16 February 1978 . 
Holzenthal, R. W. 1981. Historical biogeography and ecology of two new species of Nearctic Setodes (Trichoptera: Leptoceridae). North American Benthological Society annual meeting in Provo, Utah, 29 April 1981.

Holzenthal, R. W. and S. W. Hamilton. 1983. Endemic caddisflies of the southeastern Coastal plain: distribution and historical biogeography. Florida Entomological Society annual meeting in Clearwater. Florida, 8-12 August 1953.

Holzenthal, R. W. and S. W. Hamilton. 1984. Trichoptera diversity and endemism in the Southeastern Coastal Plain. North American Benthological Society annual meeting in Raleigh, North Carolina, 24 May 1984, in symposium entitled, "Blackwater Rivers."

Kelley, R. W. 1981. A reassessment of species groups of southeastern oxvethira (Trichoptera, Hydroptilidae) based on an analysis of the females. North American Benthological Society annual meeting in Provo, Utah, 29 April 1981.

McEwan, E. M. 1980. Biology and life history of two southeastern species of Acarodes (Trichoptera: Sericostomatidae). Entomological Society of America annual meeting in Atlanta, Georgia, 2 December 1980.

Menking, D. E. 1976. The tube-building habits of the genus phylocentropus (Trichoptera: Polycentropodidae). Georgia/South Carolina Entomological Societies joint annual meeting in Savannah, Georgia, 18 March 1976.

Morse, J. C. 1980. Trichoptera, in Symposium on the Aquatic Invertebrate Fauna of the Southeastern United States. North American Benthological Society annual meeting in Savannah, Georgia, 26-38 March 1980 .

Morse, J. C. 1981. Aquatic insect investigations in South Carolina, U.S.A. (Invitational Address) Victorian Entomoloqical Society bimonthly meeting in Melbourne, Victoria, Australia, November 1981 .

Morse, J. C. 1981. Benthological research in South Carolina, U.S.A. (Invitational Address) Victoria Branch, Limnological Society of Australia, quarterly meeting in Melbourne, Victoria, Australia, December 1981.

Morse, J. C., J. W. Chapin, D.D. Herlong and R.S. Harvey. 1979. The insects of Upper Three Runs Creek, Savannah River Plant. Georgia/South Carolina Entomological Societies joint annual meeting on Hilton Head Island, South Carolina, 23 March 1979. 
* Morse, J. C., and J. D. Culin. 1991. Bright lights and the urge to travel. South Carolina Entomological Society annual meeting, Greenville, South Carolina, 7 November 1991.

* Morse, J. C., and J. D. Culin. 1992. Attractance of caddisflies to ultraviolet light at varying distances from a stream. North American Benthological Society annual meeting, Louisville, Kentuchy, 28 May 1992.

Morse, J. C. and W. R. English. 1984. Insect community characteristics of a blackwater stream in the South Carolina Sandhills. North American Bentholoqical Society annual meeting in Raleigh, North Carolina, 24 May 1984, in symposium entitled, "Blackwater Rivers."

Morse, J. C. and R. W. Kelley. 1982. Aquatic insects of Upper Three Runs Creek, South Carolina. North American Benthological Society annual meeting in Ann Arbor, Michigan, 19 May 1982 .

THESES AND DISSERTATIONS:

Chapin, J. W. 1978. Systematics of Nearctic Micrasema (Trichoptera: Brachycentridae). Ph.D. Dissertation, Clemson University. $x v+136 \mathrm{pp}$.

* English, W. R. 1991. Ecosystem dynamics of a South Carolina Sandhilis stream. Ph.D. Dissertation, Clemson University. xiv +118 pp.

Herlong, D. D. 1978. Aquatic Pyralidae (Lepidoptera, Nymphulinae) in South Carolina. M.S. Thesis, Clemson University. viii $+42 \mathrm{pp}$.

Kelley, R. W. 1982. The micro-caddisfly genus oxyethira (Trichoptera: Hydroptilidae): morphology, biogeography, evolution and classification. Ph.D. Dissertation, Clemson University. xv + $437 \mathrm{pp}$.

McEwan, E. M. 1980. Biology and life history of the genus Agarodes (Trichoptera: Sericostomatidae) in the southeastern United States. H.S. Thesis, Clemson University. vii $+67 \mathrm{pp}$.

Menking, D. E. 1978. Biology and life history of the caddisfly genus phylocentropus (Polycentropodidae) with special reference to influences of heated water. M.S. Thesis, clemson University. $v+28 \mathrm{pp}$. 
PUBLICATIONS IN SCHOLARLY BOOKS AND REFEREED PROFESSIONAL JOURNALS,

Brigham, A. R. and D. D. Herlong. 1982. Lepidoptera, Chapter 12. In A. R. Brigham, W. U. Brigham and A. Gnilka, editors, Aquatic Insects and Oligochaetes of North and South Carolina. Midwest Aquatic Enterprises, Mahomet, Illinois. 837 pp. (pp. 12.1 $-12.361$

Bueno-Soria, J. 1981. Estudios en insectos acuaticos de Mexico I. Trichoptera (Leptoceridae). Cinco nuevas especies de oecetis McLachlan. Fol. Entomol. Mex. 49, 103-120. -- includes original description of Decetis morsei from Upper Three Runs Creek.

Herlong, D. D. 1979. Aquatic Pyralidae (Lepidoptera, Nymphulinae) in South Carolina. Florida Entomol., 62: 188-193.

Holzenthal, R. W., and S. C. Harris. 198S. The female of Setodes quttatus with distribution notes (Trichoptera: Leptoceridae). J. Kansas Entomol. Soc. S8(1):166-167.

Holzenthal, R. W. 1982. The caddisfly genus Setodes in North America (Trichoptera, Leptoceridae). J. Kansas Entomol Soc., $55(2): 253-271$.

Holzenthal, R. $W$ and R. W. Kelley. 1981. New micro-caddisflies from the southeastern United States (Trichoptera, Hydroptilidae). Florida Entomol., 66(4)1983): 464-472.

Kelley, R. W. 1981. New species of oxyethira (Trichoptera, Hydroptilidae) from the southeastern United States. J. Georgia Entomol. Soc., 16(3): 368-375.

Kelley, R. W. 1984. Phylogeny, morphology and classification of the micro-caddisfly genus oxyethira Eaton (Trichoptera: Hydroptilidae). Trans. Amer. Entomol. Soc., 110, 435-463.

Kelley, R. W. 1985. Revision of the micro-caddisfly genus Oxyethira (Trichoptera: Hydroptilidae). Part II, Subgenus Oxyethira. Trans. Amer. Entomol. Soc. 111:223-253.

Kelley, R. W. 1987. Revision of the micro-caddisfly genus oxyethira (Trichoptera: Hydroptilidae) Part III: subgenus Holarctotrichia. Proc. Entomol. Soc. Washington 88(4): 777-785.

Kelley, R. W. and J. C. Morse. 1982. A key to the females of the genus oxyethira (Trichoptera: Hydroptilidae) from the southern United States. Proc. Entomol. Soc. Washington, 84(2): 256-269.

Morse, J. C. 1981. Aquatic insect investigations in south Carolina, U.S.A. Victorian Entomol. 2(6):62-64. 
Morse, J. C., J. W. Chapin, D. D. Herlong and R. S. Harvey. 1980. Aquatic insects of Upper Three Runs Creek, Savannah River Plant, South Carolina. Part I: Orders other than Diptera. J. Georgia Entomol. Soc., 15(1): 73-101.

Morse, J. C., J. W. Chapin, D. D. Herlong and R. S. Harvey. 1983. Aquatic insects of Upper Three Runs Creek, Savannah River Plant, South Carolina. Part II, Diptera. J. Georgia Entomol. Soc., $18(3): 303-316$.

Morse, J.C. and R.W. Holzenthal. 1984. Trichoptera genera, Chapter 17. Pages 312-347 in R. W. Merritt and K. W. Cummins, eds. An Introduction to the Aquatic Insects of North America, 2nd Edition. Kendall/Hunt Pub..Co., Dubuque, lowa. 722 pp.

Oliver, D. R. and M. E. Roussel. 1983. Redescription of Brillia Kieffer (Diptera: Chironomidae) with descriptions of Nearctic species. Can. Entomol., 115: 257-279.

Saether, 0. A. 1980. Three female chironomid genitalia (Diptera). In D. A. Murray, editor, Chironomidae: Ecology, Systematics, Cytology and Physiology. Pergamon Press, New York.

Saether, 0.A. 1982. Orthocladiinae (Diptera: Chironomidae) from SE U.S.A., with descriptions of Plhudsonia, Unniella and Platysmittia $n$. genera and Atelooodella n. subgen. Entomol. scand., 13: 465-510.

Saether, 0. A. 1983. A review of the genera Doithrix $n$. gen., Georthocladius Strenzke, Parachaetocladius Wulker and Pseudorthocladius Goetghebuer (Diptera,Chironomidae; Orthocladiinae). Entomol. Scand., suppl. 20:1-100.(includes Pseudorthocladius (P.) morsei from SRP).

Schuster, G. A. and S. W. Hamilton. 1984. The genus Phylocentropus in North America (Trichoptera: Polycentropodidae). Pages 347-362 in J. C. Morse, ed. Proceedings of the 4 th International symposium on Trichoptera, Ser. Entomol. 30, Dr. W. Junk Pub., The Hague. $486 \mathrm{pp}$.

Surdick, R. F. 1981. New Nearctic Chloroperlidae (Plecoptera). Great Basin Naturalist, 41(3): 349-359.

Unzicker, J. J., V. H. Resh and J. C. Morse. 1982. Trichoptera, Chapter 9. In A. R. Briqham, W. U. Brigham and A Gnilka, editors. Aquatic Insects and Oligochaetes of North and South Carolina. Midwest Aquatic Enterprises, Mahomet, Illinois. 837 pp. (pp. $9.1-9.138$ ) 
Weaver, J. S., 111. 1984. The diversification of Lepidostomatidae. Page 421 in J. C. Morse, ed. Proceedings of the 4th lnternational Symposium on Trichoptera, Ser. Entomol. 30, Dr. W. Junk Pub., The Haque. $486 \mathrm{pp}$.

Weaver, J. S., III. 1988. A synopsis of the North American Lepidostomatidae (Trichoptera). Contrib. Amer. Entomol. Inst. $24(2)$ : 1141.

Wood, J. R., V. H. Resh and E. M. McEwan. 1982. Egg masses of Nearctic sericostomatid caddisfly genera (Trichoptera). Ann. Entomol. Soc. Amer., 75(5): 430-434.

White, D. S. 1982. Stenelmis morsei, a new species of riffle beetle (Coleoptera, Dryopoidea: Elmidae) from South Carolina. The Coleopterists Bull. $36(2): 170-174$.

White, T. R., K. J. Tennessen, R. C. Fox and P. H. Carlson. 1980. The aquatic insects of South Carolina, Part I, Anisoptera (Odonata). Bull. South Carolina Agric. Expt. Sta., Clemson Univ., Clemson, S.C., 632: 1-153.

White, T. R., K. J. Tennessen, R. C. Fox and P. H. Carlson. 1983. The aquatic insects of South Carolina, Part II, zyqoptera (Odonata). Bull South Carolina Aqric. Expt. Sta., Clemson Univ., Clemson, S.C., 648: 1072 .

\section{MANUSCRIPTS COMPLETED OR IN PREPARATION:}

* English, W.R., I. Yang, and J.C. Morse. role of aquatic plants and snags in structuring macroinvertebrate communities in blackwater Sandhilis streams.

* English, W.R. Remote sensing station for temperature, dissolved oxygen, adn $\mathrm{pH}$ with reference to aquatic macroinvertebrate distribution.

* English, W.R. and J.C. Morse. Relationships between habitat types and aquatic macroinvertebrate community structure: The implications in biological assessment of water quality.

Kelley, R. W. The micro-caddisfly qenus oxyethira (Trichoptera, Hydroptilidae): morphology, bioqeoqraphy, evolution and classification. (This work is appearing in several parts.)

Hack, E. M. Biology, life history, and larval taxonomy of the genus Agarodes (Trichoptera, Sericostomatidae) in the Southeastern United States.

* Morse, J.C., and J.D. Culin. Flight distance and attractance of Trichoptera to ultraviolet light traps. 
Morse, J. C., R. W. Kelley, E. M. Hack, C. E. Murphy and G. J. Hollod. Aquatic insects of Upper Three Runs Creek, Savannah River Plant, South Carolina, Part III, Comparative faunistics and new records. 


\section{Attachment}

\section{Ecosystem Dynamics of a South Carolina Sandhills Stream}

William R. English 
ECOSYSTEM DYNAMICS OF A SOUTH CAROLINA SANDHILLS STREAM

\author{
A Dissertation \\ Presented to \\ the Graduate School of \\ Clemson University \\ In Partial Fulfillment \\ of the Requirements for the Degree \\ Doctor of Philosophy \\ Entomology
}

by

William R. English

August 1991 
August 2, 1991

To the Graduate School:

This dissertation entitled "Ecosystem Dynamics of a South Carolina Sandhills Stream" and written by William R. English is presented to the Graduate School of Clemson University. I recommend that it be accepted in partial fulfillment of the requirements for the degree of Doctor of Philosophy, with a major in Entomology.

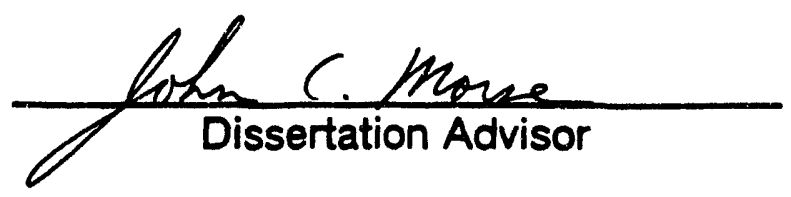

We have reviewed this dissertation and recommend its acceptance:

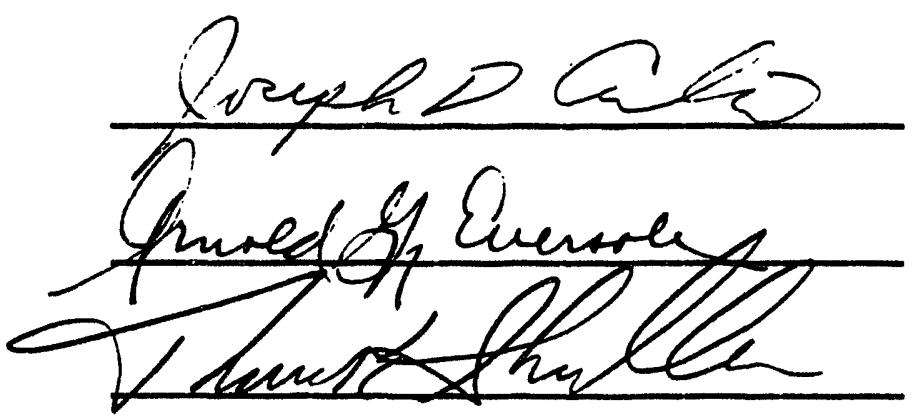

Accepted for the Graduate School:

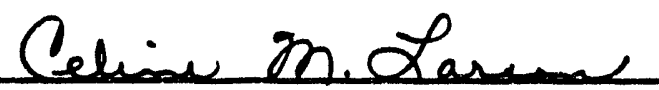


ABSTRACT

Aquatic insect faunal surveys conducted in 1976-77 and 1979-80 of Upper Three Runs Creek, South Carolina showed this blackwater, Sandhills stream, to be extremely rich in species $(650+)$. Comparisons of fauna collected between survey years showed major differences in taxonomic composition. Natural taxonomic shifts may have considerable bearing on the validity of commenly used biological indices of water quality which are based on community structure. It is essential to account for the natural variation in community structure before applying community-structure-based indices of water quality for water pollution detection. Recent literature has revealed that aquatic invertebrates exhibit heterogeneous distributions. Thus, biological monitoring must be able to account for natural spatial and temporal changes in community structure if assessments of water pollution, by these techniques, are to be considered valid. The heterogeneous distribution of aquatic invertebrates results from the patchy distribution of preferred environmental conditions. If those favored environmental conditions vary in time and space, then one would expect the inverteb، ate assemblages associated with that suite of conditions also to show variability. This research was designed to investigate selected environmental resources and determine their dynamics and the dynamics of aquatic invertebrate community structure in response to them. In so doing, the variability in community-based indices of water quality was assessed. To accomplish these tasks, a remote sensing station was developed for continuous monitoring of water chemistry. The one hour interval data showed a strong diel pattern in dissolved oxygen, $\mathrm{pH}$, and temperature which was evidence of the importance of aquatic plants to this system. The relative importance of specific 
habitat types was assessed. Sandy main channel areas covered most of the creek bottom and accumulated little organic matter. Aquatic plants altered current velocity and sorted organic matter into detrital pools. Snags were found capable of changing the distribution of aquatic plants. Pools were found to be temporary. The discharge regime was found to be very stable and predictable by Colwell's index of predictability. Macroinvertebrate sampling was conducted monthly for two years and was restricted to discrete habitat types which were: (1) sandy-bottom main channel, (2) plant stems, (3) pools, (4) snags and (5) benthic areas within plant beds. Organism density was greatest in the main channel and plant associated (plant stems and benthic areas within plant beds) habitats and lowest in pools and snags. Taxa richness was greatest in plant stem, benthic areas within plant beds, and snag habitats and lowest in the main channel and pool habitats. Diversity was greatest in benthic areas within plant beds. The biotic index showed lowest values in the main channel and plant habitats. Ratios of Ephemeropter, Plecoptera and Trochoptera to other taxa were lowest in main channel, plant, and pool habitats. Functional feeding group percentages showed that the main channel was dominated by predators (43\%), followed by scrapers (33\%), and collector-gatherers (22\%). Plant and snag habitats had $63 \%$ and $72 \%$ filter-feeders respectively. Pools had $51 \%$ collector-gatherers and $37 \%$ predators. Benthic areas within plant beds had $42 \%$ collector-gathers, $27 \%$ predators, while scrapers, filterers and shredders were represented by $16 \%, 10 \%$, and $5 \%$, respectively. Greatest percentage similarity in taxa was shown between plant stem and snag habitats $(61 \%)$ and between plant and benthic habitats (41\%). Comparisons between years 198485 showed no differences in organism abundances, taxa richness, diversity, biotic index values, or EPT ratios. 1984 and 1985 had $87 \%$ of their taxa in common. Functional feeding group categories showed only shredder 
percentages changed significantly between years. These data showed that community-based indices of water quality may not be representative of the stream if samples are taken only in specified habitats. 


\section{ACKNOWLEDGEMENTS}

I am grateful to John C. Morse, James E. Schindler, Arnold G. Eversole, Joseph D. Culin for their encouragement and assistance in development and completion of this project, and to Thomas E. Schwedler who helped toward its conclusion. Mike McCloud helped with the instrumentation development and Joe Tomasso helped with data analysis and review. Jena Johnson assisted with field work. My wife, Cathy, and children, Heather and Aaron deserve special acknowledgement for their continued love, support and understanding. None of this work could have been completed without their sacrifice. My parents, Jesse and Eva have been inspirational and always encouraging throughout my entire life. I dedicate this dissertation to them. The information contained in this dissertation was developed in the course of work funded by the U.S. Dept. of Energy's Savannah River National Environmental Research Park, Aiken, South Carolina. 


\section{TABLE OF CONTENTS}

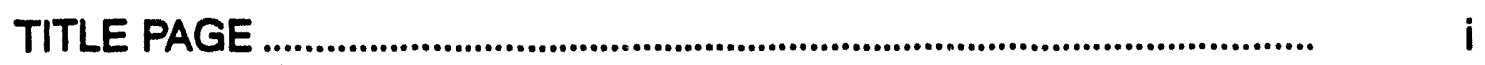

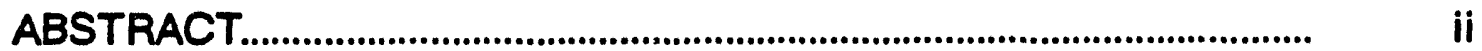

ACKNOWLEGEMENTS................................................................... v

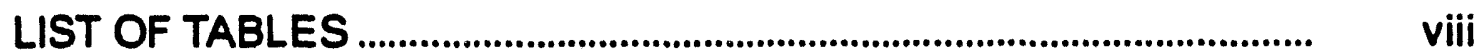

LIST OF FIGURES

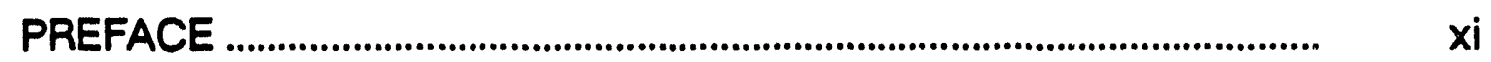

REMOTE SENSING STATION FOR TEMPERATURE, DISSOLVED

OXYGEN, AND PH WITH REFERENCE TO AQUATIC

MACROINVERTEBRATE DISTRIBUTION ................................................... 1

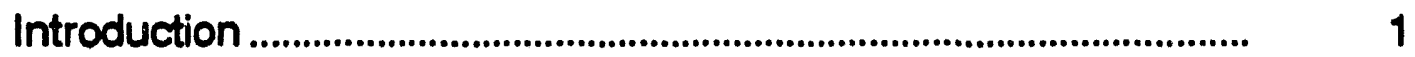

The Apparatus .................................................................................. 3

Equipment Reliability.................................................................................

Operation and Discussion ..................................................................

Temperat re.......................................................................................... 9

Dissolved Oxygen ................................................................................. 10

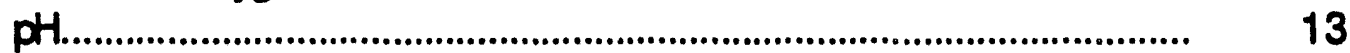

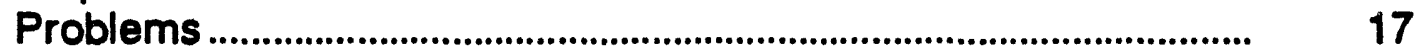

HABITAT ASSESSMENT OF A BLACKWATER STREAM
IN THE SOUTH CAROLINA SANDHILLS .........................................

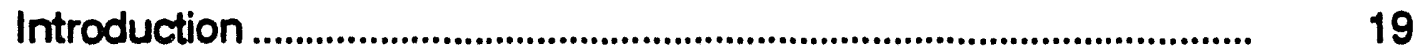

Methods and Materials ........................................................................... 21

Study Site........................................................................................... 21

Field and Laboratory Methods...................................................... 23

Quantification of Habitat Characteristics........................................ 27

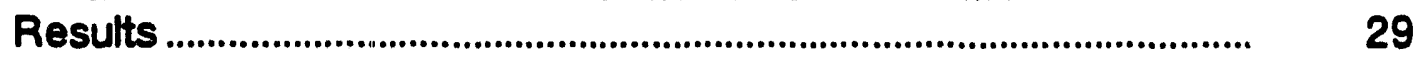

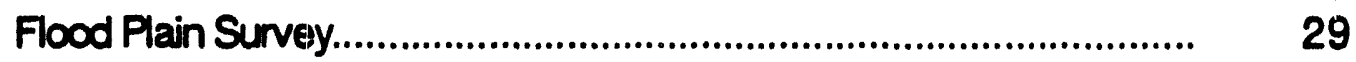

Discharge Regime............................................................................... 31

Whole Study Area Survey........................................................... 32

Quarterly Habitat Measurements.................................................... 32 
Table of Contents (Continued)

Unique Characteristics of Habitats........................................................ 46

Discussion .......................................................................................... 54

Habitat Types in UTRC: Why are They Present and

What Controls Their Distribution and Relative

Abundance?

Unique Characteristics of Each Habitat....................................... 62

Conclusions

SPATIAL AND TEMPORAL DIFFERENCES IN AQUATIC

INVERTEBRATE COMMUNITY STRUCTURE OF A

BLACKWATER STREAM IN THE SOUTH

CAROLINA SANDHILS

Introduction

Site Description

70

Field and Laboratory Methods..................................................... $\quad 70$

Results.

Spatial Variability

74

Temporal Variability

83

Discussion.

88

Spatial Variability.

88

Temporal Variability

92

Application of Biological Indices

92

Condusions.

CONCLUSIONS.

APPENDICES

A. Typical Computer Printout From Remote Site............................... $\quad 99$

B. Site Descriptions for Upper Three Runs Creek.......................... 102

C. List of Taxa, Biotic Index Pollution Tolerance Values and Functional Feeding Group Placement. 


\section{LIST OF TABLES}

Table

Page

1.1 Water quality values from U.S.G.S. site on UTRC....................

1.2 Temperature recordings and output from remote site............ 9

1.3 Dissolved oxygen and \% saturation readings........................... 12

1.4 Summary of pH values from remote sensing station ............. 15

2.1 Chemical characteristics of UTRC............................................... 23

2.2 Discharge predictability and watershed characteristics....... 31

2.3 Comparisons of discharge, Cedar Cr., Satilla R., UTRC....... 59

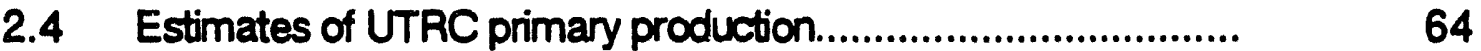

3.1 Percentage similarity in taxa ...................................................

3.2 Coefficients of variation in indices among habitats................. 83

3.3 Coefficients of variation in indices among years.................... 87

3.4 Relative abundance of filter-feeding groups........................... 90 


\section{LIST OF FIGURES}

$\begin{array}{ll}\text { Figure } & \text { Page }\end{array}$

1.1 Compartments in remote monitoring system ......................... 4

1.2 Temperature at top and bottom of UTRC ............................... 11

1.3 Diel pattern of dissolved oxygen and temperature............... 14

1.4 Diel pattern of $\mathrm{pH}$ and temperature ........................................ 16

2.1 Map of study site on UTRC showing habitats ....................... 22

2.2 Map of study site on UTRC showing flood plane .................. 30

2.3 Bottom and total surface area \% in habitats WSA................ 33

2.4 Bottom and total surface area \% in habitats (quarter).......... 34

2.5 Habitat surface area in $m$ ? ................................................... 36

2.6 Surface area occupied by aquatic plants........................... 37

2.7 Seasonal average surface area occupied by habitats........ . $\quad 39$

2.8 Seasonal average percentage for each habitat.................... 40

2.9 Flood effects on surface area of habitats............................... 41

2.10 Map of site 1 habitat showing snag effects ............................ 43

2.11 Map of site 8 habitat showing snag effects ........................... 45

2.12 Current velocity in habitats.................................................. 47

2.13 Biomass of plant species.................................................... 48

2.14 Biomass of plants / unit area................................................ 49

2.15 Biomass of algae and detritus ............................................. 51 
List of Figures (Continued)

Figure

Page

2.16 Biomass of TPOM by depth......................................................... 52

2.17 Biomass of TPOM by season........................................................ 53

2.18 Biomass of BOM by habitat........................................................... 55

2.19 Percent composition of sand ..................................................... 56

3.1 Average annual density of organisms........................................ 75

3.2 Average annual taxa richness............................................... $\quad 76$

3.3 Values for Shannon-Weaver diversity index ............................. $\quad 76$

3.4 Average annual biotic index values............................................ 78

3.5 Average annual EPT values....................................................... 78

3.6 Functional feeding group \% in main channel.......................... 79

3.7 Functional feeding group \% in plants ........................................ $\quad 79$

3.8 Functional feeding group \% in pools........................................ 81

3.9 Functional feeding group $\%$ in snags....................................... 81

3.10 Functional feeding group $\%$ in benthic habitats ................... 82

3.11 Average density of organisms among years ............................ 84

3.12 Average taxa richness among years........................................ 84

3.13 Annual values for Shannon-Weaver diversity index ............. $\quad 85$

3.14 Average biotic index among years.............................................. 86

3.15 Average EPT Ratio among years........................................... 86

3.16 Functional feeding group \% among years................................. 87 


\section{PREFACE}

Two previous aquatic insect faunal surveys of Upper Three Runs Creek (UTRC) (Morse et al. 1980, 1983, Morse and Kelley 1982) have shown this unpolluted, South Carolina, Sandhills stream to be extremely rich in species (650+). Comparisons of faunal surveys in 1976-77 and that of 1979-80 showed major taxonomic shifts. These findings, though based on qualitative sampling techniques, are supported by qualitative studies showing temporal shifts in community structure (e.g. Vannote et al. 1980, McElravy et al. 1989). Along with analysis of the taxonomic structure of invertebrates in UTRC the functional feeding group ratio (Cummins 1977, Merritt and Cummins 1984) was determined for each survey period. Morse and English (1984) found no changes in these ratios. These early data suggested that although the food resources remained fairly stable through time, species having similar feeding strategies may substitute for each other through time. If community structure is changing in both space and through time, then an accounting of this change is a necessary first step in the accurate use of community structural indices of water quality.

Research has shown that the distribution of aquatic organisms is heterogeneous in space and time (Allen 1984). The heterogeneous distribution of organisms is believed to result from the patchy, or heterogeneous distribution of favorable environmental conditions and resources (Minshall 1984). Lotic research has shown that habitat types either directly or indirectly influence environmental conditions such as current velocity, food resources and protection from predation, and ultimately influence organism distribution or community assemblages (Statzner et al. 1988, Power et al. 1988, Minshall 
1984). Much habitat-based research has focused on the relationships between the substrate types and the distribution or abundance of macroinvertebrates. Most of these studies have been conducted in temperate, forested regions, on rocky substrates (see Minshall 1984 for review). Recently, many stream ecologists have placed greater emphasis on the influence of hydraulics and geomorphology (Statzner and Higler 1985, Statzner et al. 1988, Huryn and Wallace 1988), and have shown that hydraulics and channel form determine spatial distribution of distinct habitat types, the mode of food resource accession (e.g., entrainment or deposition), and effects on invertebrate consumers. Power et al. (1988) suggested that the evaluation of macroinvertebrate habitats in streams should incorporate some measure of the predickability and range of discharges which may alter the structure, abundance and type of habitats used by aquatic organisms.

In the Southeast, researchers have recently begun looking at the importance of habitat types in sandy-bottomed rivers and streams. These aquatic systems are different from rocky bottomed streams because sandy bottoms are unstable and the physical structures which provide stable habitat types are different. Some of the first works on habitat types in southeastern sandy-bottomed streams were by Benke et al. (1984) and Smock et al. (1985). They both identified three major habitat types in blackwater rivers: snag habitats, sandy benthic main channel habitats, and muddy benthic backwater habitats. Upper Three Runs Creek has these habitat types plus an abundance of aquatic plant beds. All have been shown to function as macroinvertebrate habitats.

The objective of this research was to gain an understanding of how abiotic components of the environment directly, and indirectly, influence aquatic macroinvertebrate community structure in space and time, to determine if 
community structure variability exists, and, if so, how it affects biotic indices of water quality. To achieve these objectives, three major tasks were completed and are the bases for this dissertation:

(1) The physical and chemical dynamics of the system were determined.

(2) Spatial and temporal dynamics of habitats for aquatic macroinvertebrates were researched.

(3) The spatial and temporal variability of aquatic invertebrate communities was determined and related to water quality indices.

To achieve the first task a remote monitoring system was developed. The objective of section one is to describe a water quality monitoring system designed to accomplish the following: (1) measure temperature, dissolved oxygen and pH at short time intervals, (2) record measurements into a long term storage device that had the capacity to download information onto computers for data analysis, and (3) operate at a remote site for up to 30 days without external power. This section also provids equipment reliability data and examples of data output.

To achieve the second task, research, as described in section 2, was conducted to determine habitat-type abundances, characteristics, and ecosystem importance in UTRC. Habitat-type characteristics of interest were those which may influence the distribution of aquatic macroinvertebrates. The study considered both the spatial and temporal aspects of habitat distribution. Specific questions addressed were:

(1) Why does UTRC have the habitat types that are present?

(2) What percentage of the study area was made up of each habitat type?

(3) Do the percentages of habitat types change seasonally?

(4) What are the unique characteristics of each habitat type that may create a favorable environment for macroinvertebrates?

(5) How is each habitat type important to the character of the stream ecosystem? 
Task three is reported in section 3 of this dissertation. The objective of this task was to determine if there were spatial or temporal changes in the macroinvertebrate community structure in UTRC and assess the effects of that variability on community-structure-based water quality indices. 


\title{
REMOTE SENSING STATION FOR TEMPERATURE, DISSOLVED OXYGEN, AND PH WITH REFERENCE TO AQUATIC MACROINVERTEBRATE DISTRIBUTION
}

\begin{abstract}
Introduction
In many ecologically oriented studies the physical and chemical
\end{abstract} properties of lotic systems are measured only at the time of biological sampling, if at all. Although researchers are aware of the importance of temperature, dissolved oxygen, and pH on the life histories of aquatic organisms (Sweeney 1984), they often ignore the possibilities that changes in these and other physical-chemical characteristics exist between visits to their study sites, and discount the importance of their dynamics within the system. Temperature affects the development and growth of aquatic invertebrates by altering rates of feeding, assimilation, respiration and endocrine control (Vannote and Sweeney 1980, Sweeney and Vannote 1981). Within tolerable limits, higher, constant temperatures theoretically should result in decreased development times of aquatic macroinvertebrates. However, the few studies which have used dynamic temperature patterns found both accelerated and retarded growth rates (Headlee 1941, Huffaker 1944). Extreme temperature excursions may eliminate some aquatic macroinvertebrates. Temperatures of $20^{\circ} \mathrm{C}$ may be the upper limits of some stoneflies and mayflies (Nebeker and Lemke 1968).

Dissolved oxygen (DO) saturation is controlled primarily by temperature and dissolved oxygen levels can limit the presence of certain aquatic organisms (Hynes 1970 ). High organic loading of streams usually results in decreased DO because of bacterial decomposition. Rivers and streams with low DO levels tend to be dominated by organisms tolerant of low oxygen (Lenat et al. 1985). 
The acidification of rivers and streams directly affects the physiology of aquatic macroinvertebrates. At sublethal low pH levels, some aquatic animals can experience difficulties in osmoregulation (Hall et al. 1980). In turn, this disrupts reproduction, growth, and molting due to $\mathrm{Ca}+$ and $\mathrm{Na}+$ imbalance (Havas 1981). Acidification also results in the mobilization of toxic heavy metals from soils and sediments. When a stream receives a periodic pulse of acid it tends to show an immediate increase in drift (Hall et al. 1980). Research concerned with the affects of acid rain on biota of rivers and streams indicates that pulsed, short-duration, highly acidic events are of major concern (Wiederholm 1984).

In transport systems like rivers and streams, short-duration, pulsed events such as acid rain runoff or illegal chemical dumpings are likely to be missed by long-interval water quality sampling. Monthly, weekly or even once daily sampling of water may not reveal rapid, pulsed changes in water quality. Only a continuous monitoring system could measure and record rapid physical and chemical changes in water quality. Because most rivers and streams are not located proximal to chemical laboratories, a remote sensing system is required.

The objective of this paper is to describe a water quality monitoring system which was developed to: (1) measure temperature, dissolved oxygen and $\mathrm{pH}$ at short time intervals, (2) record measurements into a long-term storage device that had the capacity to download information onto computers for data analysis, and (3) operate at a remote site for up to $\mathbf{3 0}$ days without external power. This paper also provides equipment reliability data and examples of data output. The system was tested 'i the United State Department of Energy's Savannah River National Environmental Research Park, Savannah River Site near Aiken, South Carolina, on Upper Three Runs Creek (UTRC). 


\section{The Apparatus}

The system was designed so that a microprocessing data logger would, at set intervals, modify and log data from temperature, $\mathrm{DO}$ and $\mathrm{pH}$ probes. The logged information was placed on transportable, long-term storage (recorded on a cassette tape). The cassette was returned from the remote site and data on the tape were downloaded via a cassette-computer interface onto a computer (Figure 1.1). Once data were on the computer, water quality dynamics were analyzed and water quality changes which occurred during absence from the site was documented.

The principle processing unit of the continuous monitoring system was a Campbell CR21 Scientific Micrologger (Campbell Scientific, Inc., Logan, Utah) which has been commonly used to record and manage data at remote meteorological stations. The micrologger is a programmable calculator and data logger which records volt, millivolt and resistance inputs from a variety of meters and input devices. Two Campbell 107 thermistors were used to measure water temperature. The Campbell 107 Temperature Probe is a DC resistance thermistor. To measure temperature, a 2-volt DC excitation was sent through the thermistor and resistance was measured by the micrologger and converted to units of temperature. Dissolved oxygen was determined with a Yellow Springs Instruments (YSI) model 57 DO meter (Yellow Springs Instrument Co., Inc., Yellow Springs, Ohio). A YSI model 5331 polarographic oxygen probe was used throughout the study. The $\mathrm{pH}$ was determined with a Beckman pHI 31 temperature-compensating pH meter (Beckman Instruments, Somerset New Jersey). A Beckman pHI 31 high capacity, refillable pH probe was used throughout the study. DO and $\mathrm{pH}$ meters were operated continuously for the 20-30 day interval between visits to the remote site. The meters were connected to the millivolt input recepticales of the CR 21 micrologger. Both 


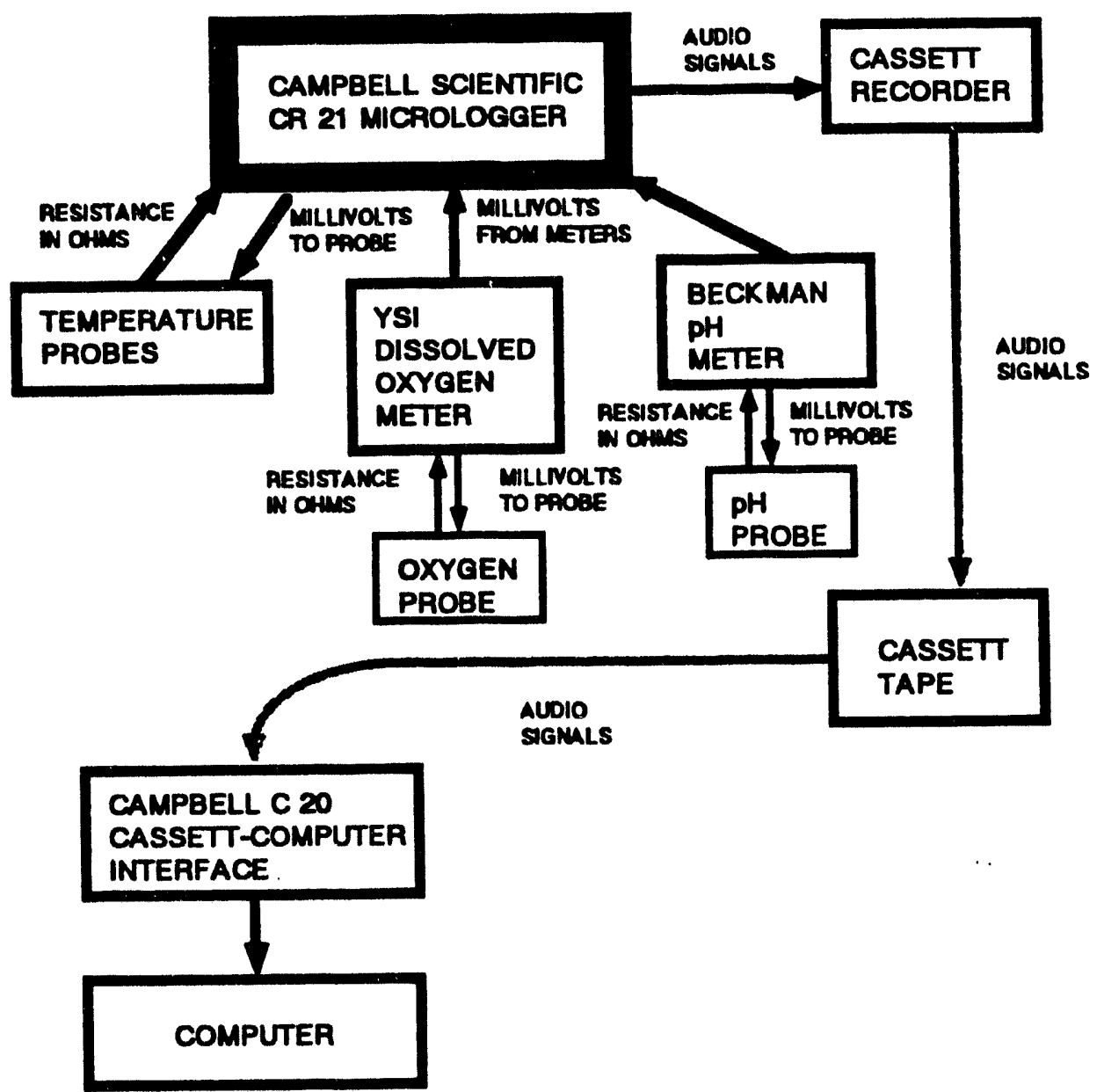

Figure 1.1. Diagram of compartments in remote monitoring system. 
meters were continuously reading and outputting water quality data (as millivolts) to the micrologger. Once each minute the micrologger sampled the input signals according to input programs specified by the user. The micrologger stored the one-minute sample data in short-term memory. Data in short-term memory were processed according to the user's needs (e.g., maximum, minimum, and mean readings) and was output into long-term memory at user-determined intervals. The battery powered micrologger was programmed to scan each minute for 60-minutes the millivolt input signals from the meters as well as the resistance signals from the thermistors. Thus, each 60 minute data point (stored in long-term memory) had 60 samples of input data (temporarily stored in short-term memory) that were processed by the micrologger to provide maximum, minimum, and mean values measured at the probes. The micrologger was programmed to use a $24-\mathrm{hr}$ clock and a Julian date calender. The output from the micrologger was developed into data summaries including maximums, minimums, and means as shown in Appendix A. Although the Campbell CR 21 micrologger has the capacity to send data directly to a printer or can interface with a telephone modem, the data from this study were transferred as audio signals from the CR 21 to a Panasonic model RO-356, battery powered, hand held, cassette tape recorder (Panasonic Co., Secaucus, New Jersey). Cassette tapes (90 $\mathrm{min}$ ) were transported from the remote site to the laboratory and read through a Campbell C20 Cassette Computer Interface at Clemson University, $190 \mathrm{~km}$ from the sample site. The C20 computer interface has RS 232 ports which allow for communication with any micro- or mainframe computer. Output from the micrologger's liquid crystal display was used for recalibration during site visits. All probes and meters were serviced and recalibrated during monthly visits to the remote site. A probe was serviced by removing attached algae, detritus and aquatic organisms. Also DO 
and $\mathrm{pH}$ probes had electrolytes replenished and were recalibrated to known standards. DO probe membranes were replaced monthly. Batteries needed to be changed monthly in the $\mathrm{DO}$ and $\mathrm{pH}$ meters and in the cassette recorder. The CR 21 micrologger required annual battery changes only.

All instrumentation was stored inside a watertight, army surplus, power generator case which was suspended from the downstream side of Treadway Bridge located on UTRC. One temperature probe was placed on the stream bottom, the other temperature probe, DO probe, and pH probe were attached to a $4 \mathrm{~m}$ length of PVC pipe which moved as a free arm from the bridge so that the probes remained in the top $20 \mathrm{~cm}$ of the water column.

\section{Equipment Reliability}

Equipment reliability was determined by three criteria. First, meter readings were checked for accuracy against known standards prior to monthly recalibration and servicing of instrumentation. Second, meter or probe fade was determined from recorded data by looking for gradual changes in values and inconsistent readings for known chemical interactions (e.g., percentage saturation of dissolved oxygen given a known temperature). Probe fade probably results from fouling of membrane surfaces or loss of electrolyte or electrolyte ionic strength. Meter fade was considered to be caused from the gradual discharge of batteries and their continuous use. Third, instrument readings were also compared with the monthly chemical reports from a United States Geological Survey (U.S.G.S.) gauging station located on UTRC approximately $3.2 \mathrm{~km}$ upstream from the remote sensing site. Because data collected at the U.S.G.S. gauging station ( $\$ 02197300$ ) were collected only during daylight hours, the confidence limits set for data considered reliable were extended for both DO and pH readings. The expansion of confidence limits was 
justified to account for nighttime values which were quite different from daytime recorded values.

To test for DO meter or probe fade a $90 \%$ saturation level for a given recorded temperature was established as the standard. Analysis of the U.S.G.S. gauging station data showed that the 36-month daytime mean DO level was at $89.59 \%$ of saturation ( \pm SE 1.30 ) for the given temperatures (Table 1.1). Ninty-nine percent confidence intervals were established around the $D O$ mean and a range of $5 \%$ of the mean was added to the confidence intervals. As a result, the DO percentage saturation confidence intervals were established as 100 to $80 \%$ saturation. Percent saturation levels outside these confidence intervals indicated an instrumentation problem and the data were considered unreliable. Nighttime DO levels are commonly lower because of respiration and the lack of photosynthetic activity. To reduce the chance of mistaking a nighttime DO reduction for a meter or probe fade, 10 consecutive hours of readings outside the confidence intervals were allowed. The time of meter or probe fade was set at the first of 10 deviations from the confidence intervals above or below the $90 \%$ saturation level.

Table 1.1. Summary of water quality values from the U.S.G.S. site \# 02197300 located approximately $3.2 \mathrm{~km}$ upstream from the instrumentation box.

\begin{tabular}{lrrrrr}
\hline VARIABLE & N & MEAN & (SE) & RANGE & C.V \\
\hline TEMP & 146 & 16.40 & $(0.33)$ & $7.0-24.0$ & 24.4 \\
\% SATURATION & 36 & 89.95 & $(1.32)$ & $97.3-84.6$ & 13.4 \\
DO & 110 & $9.03(0.12)$ & $6.7-11.8$ & 13.7 \\
PH & 110 & $5.85(0.06)$ & $4.4-8.7$ & 9.9 \\
\hline
\end{tabular}


Tests to determine $\mathrm{pH}$ meter and probe fade were less stringent than those applied to DO instrumentation. In this poorly buffered stream (total alkalinity $2-5 \mathrm{ppm}$ as $\mathrm{CaCO}_{3}$ ), daytime measurements of $\mathrm{pH}$ values at the U.S.G.S. gauging station were extremely variable (see Table 1.1) and, because of expected natural diel fluctuations, could not be used to test against remote site readings. Also, $\mathrm{pH}$ readings could not be indirectly tested against other known chemical interactions as with the relationship of DO solubility to ambient temperatures. Because this paper is concerned with the reliability of $\mathrm{pH}$ meter and probe output, statistical analysis was conducted on $\mathrm{pH}$ values rather than on $\mathrm{pH}$ values converted to hydrogen ion concentrations (moles/iter). Data from $\mathrm{pH}$ values were converted to hydrogen ion concentrations (moles/iter) in Appendix $A$, and appropriate statistical analysis may be applied to these transformed data to test for differences in hydrogen ion concentrations. However, that type of analysis is beyond the scope of this paper. The standard set for detection of $\mathrm{pH}$ meter or probe fade was that readings should stay within the range shown in the 110-day U.S.G.S. station data, but readings may go beyond the range during nighttime (respiration period) for no more than 10 consecutive hours. The time of meter or probe fade was set at the first of 10 consecutive deviations from the range established from U.S.G.S. data (Table 1.1). The CR 21 micrologger were reported by the manufacturer and found to be reliable within $0.02 \%$ of the full-scale range for voltage measurements. Resistance and conductivity were within $0.01 \%$ accuracy of the full-scale bridge output. Temperature probes were reported by the manufacturer to be accurate within $\pm 1.5^{\circ} \mathrm{C}$. Probe temperature readings were also tested against standard glass thermometers during monthly recalibrations and were always within $\pm 1.25^{\circ} \mathrm{C}$. 


\section{Operation and Discussion}

Temperature

Temperature probes were very reliable throughout the study (Table 1.2) and during monthly visits to the remote site were always within $1.25^{\circ} \mathrm{C}$ of laboratory-certified glass thermometers. Temperatures were always within $2.5^{\circ} \mathrm{C}$ of the daytime, monthly readings taken upstream at the U.S.G.S. gauging station. A post-field-study test of the two temperature probes gave average readings $0.48^{\circ} \mathrm{C}(\mathrm{SE}=0.27, \mathrm{n}=200)$ apart in the $20-25^{\circ} \mathrm{C}$ range. The temperature probes were not replaced during the 2 years of this study and no repairs were necessary.

Table 1.2. Summary of temperatures at the top and bottom of the water column recorded with remote sensing devices located on Upper Three Runs Creek, Savannah River Site, SC. The month of August was divided into four parts so that probe and meter fade could be detected. HRS = number of hours of observations in a data set. Provided are means (tSE) and coefficient of variation (CV). Top temperatures were significantly different from bottom temperatures for April, May and June at $\alpha=0.05$.

\begin{tabular}{lllll}
\hline MONTH & HRS & $\begin{array}{l}\text { TEMP } \\
\text { TOP }\end{array}$ & CV & \multicolumn{1}{c}{ TEMP } \\
& & & & \\
\hline April & 538 & $17.35(0.07)$ & 8.98 & $16.59(0.06) 8.71$ \\
May & 481 & $19.03(0.03)$ & 3.94 & $18.14(0.03) 3.81$ \\
June & 793 & $20.44(0.03) 3.94$ & $20.00(0.03) 4.35$ \\
Aug-A & 149 & $20.48(0.08)$ & 4.52 & \\
Aug-B & 148 & $20.75(0.03)$ & 1.55 & \\
Aug-C & 147 & $20.94(0.03)$ & 1.89 & \\
Aug-D & 108 & $20.97(0.03)$ & 1.53 & \\
\hline
\end{tabular}

Temperature readings showed a diel pattern as expected (Figure 1.2) with solar input resulting in warmer temperatures during the day. The two 
separate temperature probes showed differences in the top and bottom temperatures within UTRC. Differences were significant $(\alpha=0.05)$ for April, May and June of 1985 (Table 1.2). No bottom temperature readings were taken in August. The possible cause for thermal differences in UTRC was that solar radiation heated the surface water and buoyant, warmed water did not mix well with the more dense, cooler waters located on the bottom of the stream bed. The implications of differences in temperature from top to bottom of a stream at a single location are important. The depth and resultant temperature at which an aquatic insect resides may effect the development time and fecundity of that individual (Vannote and Sweeney 1980). The range of possible temperature profiles within which a single population may reside could be an important factor contributing to the many asynchronous or prolonged emergence patterns shown previously by Morse et al. (1980).

\section{Dissolved Oxygen}

Dissolved oxygen readings were always below test standards when instrumentation was recalibrated following each month of operation. By the established criteria, the longest reliable DO records were for $107 \mathrm{hrs}$. in late August 1985 and 106 hrs. in June 1985 (Table 1.3). August also had two periods of 84 and $80 \mathrm{hrs}$, when readings were reliable. May readings were accurate for 70 hrs., April for $27 \mathrm{hrs}$. and during the August-C period, meter or probe readings were reliable for only 11 hrs. The monthly mean DO and \% saturation values were extremely variable. The coefficient of variation for wholemonth DO data ranged from 16.43 for April 1985 to 50.83 for June 1985. Data were reanalyzed using data collected only during the time instrumentation was considered reliable and the coefficient of variation of the data was reduced to at least $1 / 3$ of that shown for all data collected between visits to the remote site. 


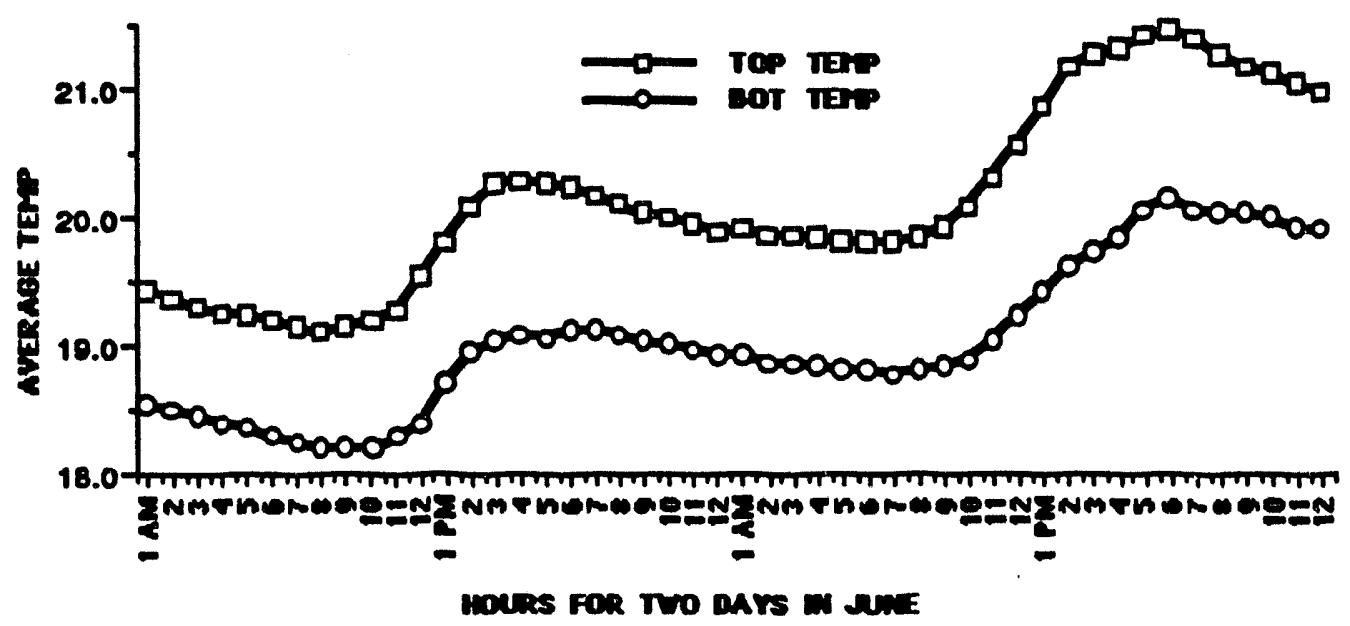

Figure 1.2. Example of temperature differences at the top and bottom of the water column in UTRC. 
Table 1.3. Summary of dissolved oxygen (DO) and \% saturation (\% Sat) values recorded with remote sensing devices located on Upper Three Runs Creek, Savannah River Site, SC. The values for months followed by "reliable" show means for data collected before the meter or probe began to fade. HRS = number of hours of observations in a data set. The month of August was divided irto four parts to showy changes in values through time. Provided are means (tSE) and coefficient of variation (CV).

\begin{tabular}{lrcrrr}
\hline MONTH & HRS & DO & CV & \% Sat. & CV \\
\hline April & 538 & $6.71(0.05)$ & 16.43 & $69.95(0.49)$ & 16.37 \\
April reliable & 27 & $8.48(0.09)$ & 5.36 & $85.89(0.86)$ & 5.18 \\
May & 481 & $9.20(0.10)$ & 23.04 & $99.00(1.03)$ & 22.66 \\
May reliable & 70 & $7.81(0.07)$ & 7.53 & $82.8(0.77)$ & 7.88 \\
June & 793 & $4.60(0.08)$ & 50.83 & $50.89(0.91)$ & 50.12 \\
June reliable & 106 & $8.59(0.07)$ & 8.75 & $95.18(0.76)$ & 8.24 \\
Aug-A & 149 & $7.44(0.04)$ & 6.76 & $82.52(0.48)$ & 7.11 \\
Aug-A reliable & 80 & $7.40(0.38)$ & 4.61 & $83.34(0.47)$ & 5.03 \\
Aug-B & 148 & $7.48(0.03)$ & 5.07 & $83.46(0.37)$ & 5.42 \\
Aug-B reliable & 84 & $7.65(0.03)$ & 3.97 & $85.21(0.40)$ & 4.34 \\
Aug-C & 147 & $7.28(0.03)$ & 4.62 & $81.60(0.36)$ & 5.33 \\
Aug-C reliable & 11 & $7.51(0.05)$ & 2.20 & $84.72(0.60)$ & 2.24 \\
Aug-D & 107 & $8.02(0.15)$ & 18.99 & $89.98(1.73)$ & 19.99 \\
Aug-D reliable & 107 & $8.02(0.15)$ & 18.99 & $89.98(1.73)$ & 19.99 \\
& & & & & \\
\hline
\end{tabular}


DO levels and \% saturation values were less variable in the partitioned, August data but the coefficient of variability was reduced by at least $20 \%$ when the abbreviated, reliable data were reanalyzed.

During the spring and summer of 1985, aquatic macrophytes (Sparoanium americanum Nuttall and Potamogeton epihydrus Rafinesque) made up approximately $25 \%$ of the bottom area of UTRC. Dissolved oxygen readings showed a diel pattern associated with photosynthetic activity from the high plant abundance in UTRC. Daytime solar input resulted in increased photosynthetic activity and the subsequent release of dissolved oxygen into the system (Figure 1.3). Nighttime respiration by plants, animals, and bacteria removed oxygen from the system (Cole 1983). Solar radiation also caused the DO pattern to be quite similar to that of temperature. Dissolved oxygen levels during the period of this study were never observed to be low enough to have acute impact on the aquatic invertebrate community. Chronic impacts were not observed either because they did not occur or because their effects were too subtle.

$\mathrm{pH}$

Readings of pH values were always below the test standards when the instrumentation was recalibrated following each month of operation. Analysis of recorded data from the $\mathrm{pH}$ meter showed that, by the author's established criteria, the $\mathrm{pH}$ probe and meter gave reliable readings much longer than did the DO instrumentation. Most readings appeared reliable for the interval between visits to the remote site (Table 1.4). Only the readings in April 1985 became unreliable between visits. April data also had the greatest variability. The time period for reliable pH readings in April was adjusted to $237 \mathrm{hrs}$ but the CV remained highest. 


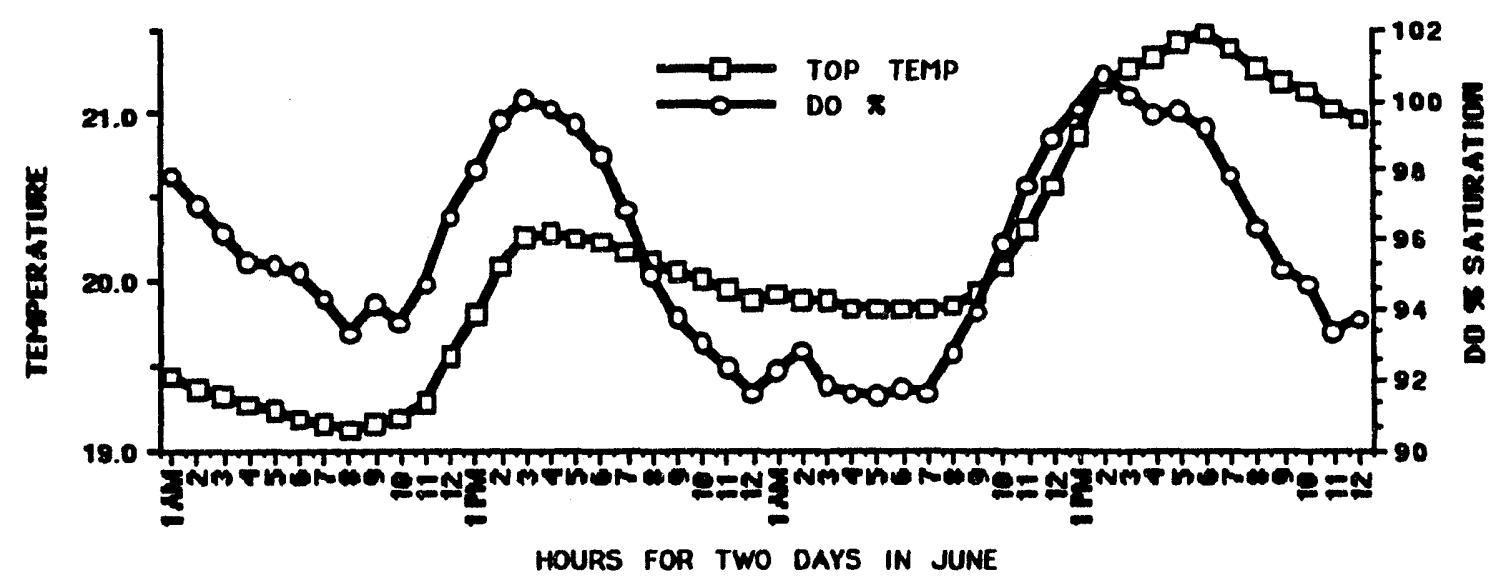

Figure 1.3. Example of the diel pattern of dissolved oxygen saturation levels and temperature for two days in June. 
Table 1.4. Summary of $\mathrm{pH}$ values recorded with remote sensing devices located on Upper Three Runs Creek, Savannah River Site, SC. The values for months followed by "reliable" show means for data collected before the meter or probe began to fade. HRS = number hours of observations in a data set. Provided are means (tSE), range and coefficient of variation (CV).

\begin{tabular}{lcccr}
\hline MONTHS & HRS & MEAN & RANGE & CV \\
\hline APRIL & 538 & $7.83(0.07)$ & $4.72-10.68$ & 25.88 \\
APRIL- & & & & \\
reliable & 237 & $5.67(0.07)$ & $4.72-8.63$ & 18.34 \\
MAY & 481 & $5.17(0.02)$ & $4.48-6.67$ & 10.26 \\
JUNE & 793 & $5.79(0.01)$ & $5.53-6.79$ & 4.19 \\
AUG-A & 149 & $5.02(0.04)$ & $4.45-6.41$ & 9.18 \\
AUG-B & 148 & $5.25(0.04)$ & $4.30-6.73$ & 10.00 \\
AUG-C & 147 & $5.79(0.04)$ & $5.17-6.67$ & 7.89 \\
AUG-D & 108 & $5.68(0.05)$ & $5.12-6.77$ & 8.39 \\
& & & & \\
\hline
\end{tabular}

The recorded data showed a diel pattern for pH (Figure 1.4) which was another indication of the influence aquatic plants had on the water chemistry in this poorly buffered stream. During daylight, removal of $\mathrm{CO}_{2}$ from the water by photosynthesizing aquatie plants causes the $\mathrm{pH}$ to rise. At night, $\mathrm{CO}_{2}$ is added back to the water through respiration of the combined aquatic community such that the $\mathrm{pH}$ falls. Respiratory $\mathrm{CO}_{2}$ causes the $\mathrm{pH}$ to decrease because $\mathrm{CO}_{2}$ in water acts as an acid.

$$
\mathrm{CO}_{2}+\mathrm{H}_{2} \mathrm{O} \rightleftharpoons \mathrm{HCO}_{3}^{-}+\mathrm{H}^{+}
$$

The degree of pH fluctuation in water is a function of the amount of $\mathrm{CO}_{2}$ removed and added by the whole stream community and the total alkalinity of the waterway. Throughout this study $\mathrm{pH}$ values were very low. According to 


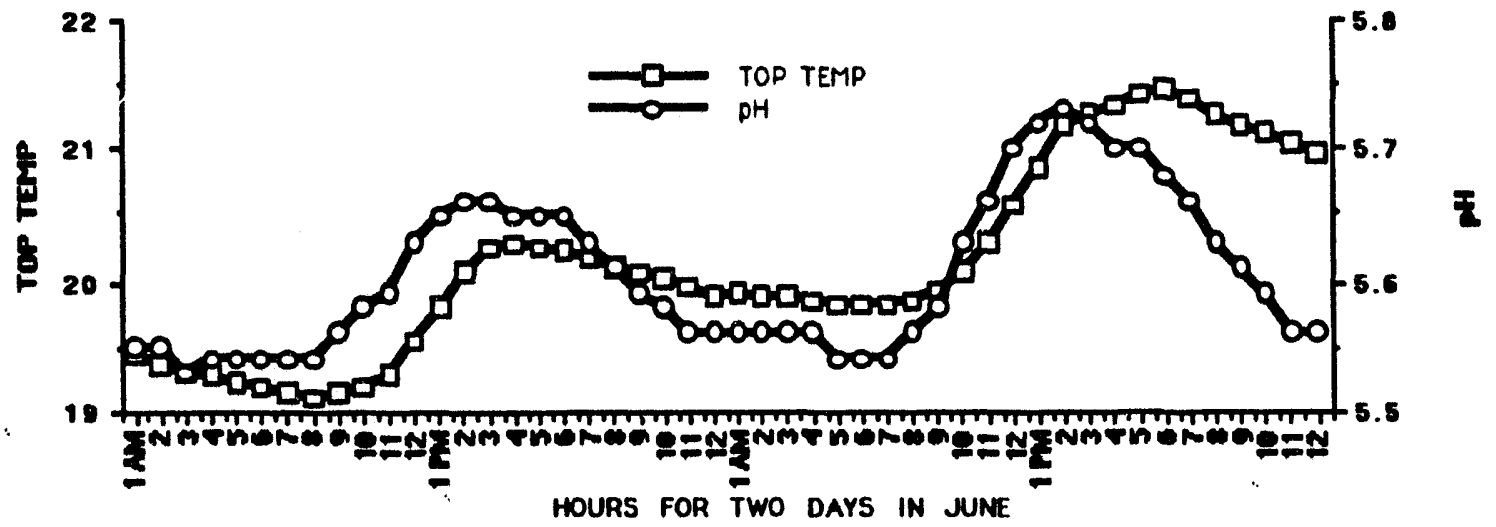

Figure 1.4. Example of the diel pattern of $\mathrm{pH}$ and temperature for two days in June. 
Wiederholm (1984), levels this low could have eliminated a great number of species and in particular decreased mayfly taxa richness. However, the fluctuations between low (4.3) and medium (6 to 8) pH levels had no observed effects on species richness (321) or mayfly taxa abundance (32) (Morse et al. 1980). Perhaps fluctuations out of the critical zone of pH levels decreased the detrimental effects.

\section{Problems}

The remote sensing station had several problems. The natural phenomena which caused the most trouble were strikes of lightning in the vicinity of the sensing station which knocked out the entire system until the next scheduled visit. Lightning protection was included in the design and construction and protected the system from two of the three lightning strikes. One strike caused sufficient damage so that the processor needed to be repaired. The two other strikes simply deprogrammed the micrologger and only reprogramming was necessary to restart the remote sensing system.

Probes suspended in the water column provided an excellent substrate to which aquatic insects, particularly net-spinning caddisflies, attached themselves and their shelters or feeding apparatus. Probes needed continual cleaning to remove invertebrates, attached algae, other aquatic plants and detritus. The slotted protective cover of the dissolved oxygen meter was particularly favorable to macroinvertebrate colonization and the use of the DO probe by aquatic organisms may have caused greater unreliability than the simple rod-shaped pH probe which was colonized to a lesser extent.

Wasps and ants found the instrument enclosure a favorable site for colonization and were always protective of their nest sites. 
The equipment at this remote, high-security site was free from vandalism, but other sites outside a controlled access area could experience problems.

Monthly servicing and recalibration took nearly 2 hrs. Most time was expended on $\mathrm{DO}$ and $\mathrm{pH}$ probe cleaning, electrolyte rejuvenation and recalibration.

The information in the data set needed to be proofread because the printed output showed some unusual values. For example, bottom temperatures in June dropped during a $24 \mathrm{hr}$ period from $19.4^{\circ} \mathrm{C}$ to approximately $11^{\circ} \mathrm{C}$ then returned back to $19^{\circ} \mathrm{C}$. Aiso, temperature readings were recorded at $400^{\circ} \mathrm{C}$ on two separate occasions. Most problems with extraneous data can be solved by checking the data for extreme value excursions.

The remote sensing station worked quite well over short periods of time and may find the most practical application in the assessment of short-duration events ( 2-3 days) when the investigator cannot always be present. It may find some utility in monitoring pulsed events such as stream water quality responses to acid precipitation. 


\section{HABITAT ASSESSMENT OF A BLACKWATER STREAM}

\section{IN THE SOUTH CAROLINA SANDHILLS}

\section{Introduction}

The distribution of aquatic organisms is known to be heterogeneous in space and time (Allen 1984). Given that most organisms are capable of dispersion from their birth site, the heterogeneous distribution of organisms is believed to result from the patchy or heterogeneous distribution of favorable environmental conditions and resources (Minshall 1984). Lotic research has shown that habitat types directly or indirectly influence environmental conditions such as current velocity, food resources and protection from predation. These conditions ultimately influence organism distribution or community assemblages (Statzner et al. 1988, Power et al. 1988, and Minshall 1984). The reasons for the links between community types and habitat types are seldom simple or direct. For example, some filter-feeding organisms select smooth, bedrock-outcrop habitat types on the basis of current velocity which allows them to strain fine particulate organic matter (FPOM) from the water column (Huryn and Wallace 1988). On the other hand, shredding-detritivores are commonly associated with coarse particulate organic matter (CPOM) and leaf packs and are often found in rocky, riffle habitat types with cobble-sized substrates that sort CPOM into interstitial areas or cause leaf pack formation (Minshall and Minshall 1977, Huryn and Wallace 1988). In both examples, lotic organisms were associated with food resources, but the habitat type dictated the composition and availability of the specific food resource. Much habitat-based research has focused on the relationships between the substrate type and the distribution and abundance of 
macroinvertebrates. Most of these studies have been conducted in temperate, forested regions, on rocky substrates (Minshall 1984 for review).

Recently, stream ecologists have placed greater emphases on the influence of hydraulics and geomorphology (Statzner and Higler 1985, Statzner et al. 1988, Huryn and Wallace 1988), and have shown that hydraulics and channel form determine spatial distibution of distinct habitat types, the mode of food resource accession (e.g., entrainment or deposition), and effects on invertebrate consumers. Power et al. (1988) suggested that the evaluation of macroinvertebrate habitats in streams should incorporate some measure of the predictability and range of discharges which may alter the structure, abundance and type of habitats used by aquatic organisms.

In the Southeast, researchers have recently begun looking at the importance of habitat types in sandy-bottomed rivers and streams. These aquatic systems are different from rocky bottomed streams because sandy bottoms are unstable and the physical structures which provide stable habitat types are different. One of the first works on habitat types in Southeastern sandy-bottomed streams was by Benke et al. (1984). They identified three major habitat types in a large blackwater river on the Georgia Coastal Plain and found that snag habitats had greater production than the sandy benthic main channel habitat or the muddy benthic backwater habitat. Smock et al. (1985) investigated the relationships between habitat and macroinvertebrates in a sandy-bottomed blackwater stream in South Carolina. Habitat types examined were main stream channel sediments, muddy banks, snags, leaf packs and leaf blades of Sparganium americanum Nuttall.

The objective of this research was to determine habitat types, and their abundances, characteristics, and ecosystem importance in Upper Three Runs Creek (UTRC), South Carolina. Habitat type characteristics of interest were those 
which may influence the distribution of aquatic macroinvertebrates. The study considered both the spatial and temporal aspects of habitat distribution. Specific questions addressed were:

(1) Why does UTRC have the habitat types that are present?

(2) What proportion of the study area consisted of each habitat type?

(3) Do the proportions of habitat types change seasonally?

(4) What are the unique characteristics of each habitat type that may create a favorable environment for macroinvertebrates?

(5) How is each habitat type important to the character of the stream ecosystem?

\section{Methods and Materials}

Study Site

The study site was located on UTRC that is an extensively studied, unpolluted, blackwater stream that drains through the Sandhills region of South Carolina. The site extended approximately $100 \mathrm{~m}$ above and below Treadway Bridge (Figure 2.1) that crossed UTRC within approximately $2 \mathrm{~km}$ of the northern boundary of the U.S. Dept. of Energy's Savannah River National Environmental Research Park near Aiken, South Carolina. UTRC is a third order stream (Strahler 1957) with a drainage area of approximately $225 \mathrm{~km}^{2}$ and a mean annual discharge over 16 years of $3.08 \mathrm{~m}^{3} / \mathrm{sec}$ as measured at U.S.G.S. station $\# 02197300$ located $3.2 \mathrm{~km}$ upstream of the study site. Other important chemical characteristics are provided in Table 2.1. The main channel and banks of UTRC are composed primarily of unconsolidated sandy material which was laid down approximately 36 to 58 million years ago during the Eocene Epoch and is called the Barnwell formation (Langley and Marter 1973). 


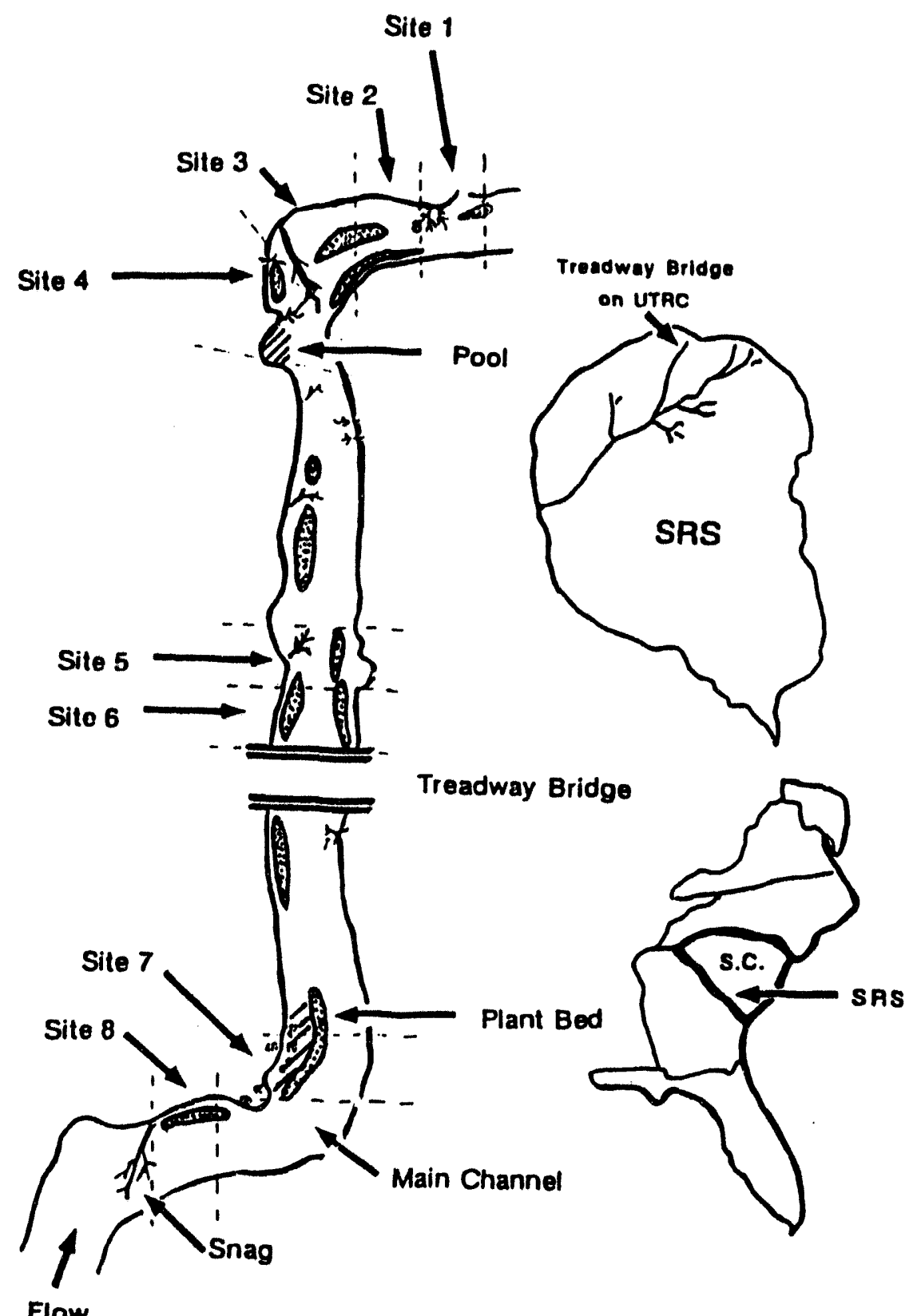

Figure 2.1. Map of study area on Upper Three Runs Creek (UTRC), South Carolina showing its location on the Savannah River Site in southeastern North America, the 8 sampling sites and representations of the habitat types and their location within the study area. Stippled areas are macrophyte beds, parallel lines are pools, tree branch shapes are snags, and unmarked areas are the sandy bottomed main channel. 
Table 2.1. Summary of chemical characteristics of Upper Three Runs Creek collected for 16 yrs at U.S.G.S. station \# 02197300 , approximately $3.8 \mathrm{~km}$ upstream of the study site.

\begin{tabular}{|c|c|c|c|}
\hline VARIABLES & $\mathbf{N}$ & MEAN & RANGE \\
\hline Temperature & 146 & 16.40 & $7.0-24.0$ \\
\hline Dissolved Oxygen & 110 & 9.03 & $6.7-11.8$ \\
\hline $\mathrm{pH}$ & 110 & 5.85 & $4.4-8.7$ \\
\hline $\begin{array}{l}\text { Alkalinity } \\
\left.\text { (mgl- } \mathrm{CaCO}_{3}\right)\end{array}$ & 35 & 2.00 & $0.2-3.5$ \\
\hline $\begin{array}{l}\text { Conductivity } \\
\text { (umhos } / \mathrm{cm} \text { ) }\end{array}$ & 32 & 23.50 & $20.0-28.0$ \\
\hline
\end{tabular}

Field and Laboratory Methods

\section{Flood Plane Survey}

Prior to the investigation of the UTRC channel proper, a general survey was conducted in the flood plain region around the study site to determine the hydrologic history of the site. Maps were developed to show geomorphic structures such as meander cutoffs, abandoned channels and oxbow-type depressions as were discussed by Leopold et al. (1964).

\section{Discharge}

Colwell's (1974) equations of predictability were applied to 16 years of monthly discharge data on UTRC collected at the upstream U.S.G.S. station. Colwell's (1974) equations have been applied to flow data by Gurtz (1984) and an application example was provided by Resh et al. (1988). The equations provided an index of predictability in flow regimes. Predictability values may 
range from 0 (not predictable) to 1 (maximum predictability) and are made up of two components: constancy and contingency. Constancy of discharge is a measure of the change in amplitude of flow, while contingency is a measure of seasonality. The ratio of contingency to predictability is the proportion of total predictability due to seasonality; the remainder is due to constancy through time.

\section{Habitats}

Habitats of concern were determined by pre-study sampling which showed that most aquatic macroinvertebrates were found within five distinct habitat types. These habitat types were categorized as:

(1) "Main channel" habitats were areas composed of a sandy substrate, no other physical obstructions and high flow velocities.

(2) "Aquatic plant beds" were composed primarily of two species of aquatic plants which formed semi-stable beds of mixed or singlespecies stands.

(3) "Pools" were sections where flow velocity was very low and detrital material formed deep deposits.

(4) "Snags" were structures consisting of exposed tree roots, limbs or trunks which extended into the creek channel.

(5) "Miscellaneous" habitats were primarily side channels and small riverlets which flowed from the main channel into the heavily forested floodplain or areas with muddy bottom and flowing water.

Two different survey techniques were used to determine habitat characteristics. The objective of survey 1 was to quantify the occurrence of the five different habitat types located within a $190 \mathrm{~m}$ section of UTRC. This survey was termed the whole study area (WSA) survey. From this initial, broad-scale survey, a more intensive, follow-up study was developed to evaluate in detail habitats within 8 smaller study sites within the $190 \mathrm{~m}$ section initially investigated in the WSA survey (Figure 1). Habitat-type quantifications were made quarterly 
for two years at the 8 sampling sites and data were used to evaluate temporal and spatial changes in habitat dimensionality. Information collected quarterly from the 8 sites was termed quarterly habitat $(\mathrm{QH})$ data.

Terminology used to describe habitat types was as follows. "Bottom surface area" is that area of the creek bottom that is occupied by a particular habitat type. "Total surface area" takes into account the bottom surface area of a habitat type and includes all the area present because of that habitat's physical structure. Bottom surface area is two dimensional on a single plane, total surface area is two dimensional on multiple planes. Main channel bottom surface area and total surface area if the bottom will be the same. Aquatic plant beds should have much less bottom surface area than total surface area because of the numerous ribbon-like plants raising from the bottom into the water column.

\section{Whole Study Area}

The locations of 10 transects were randomly selected within the $190 \mathrm{~m}$ long study area. Each transect was $2 \mathrm{~m}$ wide and ran perpendicular to the creek channel. Transect length was variable and was measured from the center of the main channel to the edge of the northern or southern creek bank. Total transect "bottom surface area" was determined as was the "bottom surface area" of each habitat type recognized. Only the portion of each habitat type within the $2 \mathrm{~m}$ wide transect section was quantified. Main channel, side-channel and pool surface areas were determined by measuring the lengths and widths of each habitat type for every occurrence in the transect section. Snag habitat surface area was estimated by considering each snag or tree limb as a collection of cylinders. All possible snags were removed to the lab and length and radius data were recorded for each cylindrical portion of a snag collected. Snag material longer 
than $30 \mathrm{~cm}$ with more than 25 branches was subsampled and total surface area was estimated from the subsample.

The surface area in each transect provided by aquatic macrophytes was determined by first measuring the "bottom surface area" of the creek bottom occupied by the aquatic macrophyte bed. Within plant beds two major species of aquatic plants were found $\mathbf{S}$. americanum and Potamogetom epihydrus Rafinesque. To estimate the "total surface area" provided by an aquatic macrophyte bed, the "bottom surface area" of each plant species in a plant bed was estimated and a $200 \mathrm{~cm}^{2}$ sample was collected from a section of each species. The total number of plants within each $200 \mathrm{~cm}^{2}$ sample were counted and their lengths measured. The surface area of individuals of each species of plant was determined by measuring the length of a stem section and then placing that section of plant in a Licor TM leaf area meter. This apparatus calculated plant surface areas (one side). After measuring plants of $\underline{\mathbf{S}}$. a.nericanum and $\mathbf{P}$. epihydrus with a wide variety of shapes and lengths, a length to surface area regression formula was developed. The regression formula for $\mathbf{S}$. americanum was

$$
Y=0.2958 X+(-59.38) ; \quad\left(r^{2}=0.951\right) .
$$

The regression formula for $\underline{P}$. epihydrus was

$$
Y=1.771 X+(-23.996) ;\left(r^{2}=0.898\right) \text {. }
$$

Because aquatic organisms use both leaf surfaces, the surface areas determined through these regression equations were doubled. All surface area measurements were made to the nearest square centimeter. 


\section{Quarterly Measurements}

Each quarter for two years, habitats were quantified in each of 8 sample sites (Figure 2.1). These sites were selected because each possessed at least three of the habitat types recognized as important in the preliminary survey. The boundaries of each site were permanently marked and stream-side reference points were established so that consistent measurements and position mapping of mobile habitat types could be achieved. Each site was surveyed with compass and tape measure, mapped and drawn to scale on graph paper. Through these quarterly measurements, seasonal changes in position and relative habitat abundance could be determined. Individual habitat types were measured for bottom and total surface area using the methods described previously for the WSA survey. The boundaries, dimensions and description of the $\mathbf{8}$ sites are provided in Appendix B.

Percentage of habitat types were compared among sites using analysis of variance (ANOVA) on the square roots of the proportion data which were arcsine transformed (to normalize), and least significant difference (LSD) tests were applied in the same manner to determine whether habitats diffed in abundance among sites (Zar 1974). Tests were conducted to determine differences between creek bottom areas and total surface areas among habitat types. ANOVA followed by LSD was used to test differences between habitat types for parameters such as current velocity, transport particulate matter (TPOM), benthic organic matter (BOM), and standing crop biomass of plant material.

\section{Quantification of Habitat Characteristics}

Current velocity in and around different habitat types was measured with a Marsh-McBirney, Inc., Model 201, electromagnetic, portable current meter that had an accuracy of $\pm 2.13 \mathrm{~cm} / \mathrm{sec}$. The organic carbon biomass (food resource) 
produced by the two dnminant species of aquatic plants was estimated by establishing a length to ash free dry weight (AFDW) regression formula from 200 $\mathrm{cm}^{2}$ samples taken from plant beds in each of the 8 sample sites. The length to AFDW regression formula established for $\mathbf{S}$. americanum was

$$
Y=0.0294 X+(-0.12197) ;\left(r^{2}=0.86 ; n=16 \text { sampies }\right) \text {. }
$$

The regression formula for $P$. epihydrus was

$$
Y=0.0 .0506 X+(-0.0456) ;\left(r^{2}=0.99 ; n=19 \text { samples }\right) \text {. }
$$

The length to weight regression formula was applied to the length data of the sampled plants and the resulting value adjusted to account for plant surface area in the whole aquatic macrophyte bed.

Biomass and taxonomic composition of the epiphytic community located on the leaf surface of $\underline{S}$. americanum and $\underline{P}$. epihydrus was determined by cutting plant leaves into two 10-cm-long strips and removing microscopically all material not epiphytic in origin (e.g., aquatic animals and their capture nets). One half of the strips collected from individual plants were examined microscopically for percentage occurrence of algal species. The other half of the plant strips were washed and gently scraped clean of detritus and epiphytes (diatoms and attached algae). Material was collected and filtered through pre-ashed and preweighed glass fiber filters (Gelman type A-E, $0.45 \mathrm{um}$ ). The material was dried at $60^{\circ} \mathrm{C}$ for $24 \mathrm{hrs}$, weighed and ashed at $550^{\circ} \mathrm{C}$ for $1 / 2 \mathrm{hr}$ to determine AFDW of the epiphytic compliment.

The quantity of TPOM was determined by suctioning water into a $500 \mathrm{ml}$ container with a hand centrifugal pump (Bunny Pump). Water was collected quarterly from beneath Treadway Bridge at the top, middle, and bottom of the $2 \mathrm{~m}$

$=$ water column. The AFDW (an approximation of organic matter) was determined by filtering $500 \mathrm{ml}$ of collected material through pre-ashed and pre-weighed, 
glass fiber filters (Gelman type A-E, $0.45 \mathrm{um}$ ). Filter and filtrate were dried at $600 \mathrm{C}$ for $24 \mathrm{hrs}$, weighed, ashed at $550^{\circ} \mathrm{C}$ for $1 / 2 \mathrm{hr}$ and reweighed.

Deposition of BOM within habitat types was determined by taking $3.3 \mathrm{~cm}$ core samples. The core sampler was pressed into the substrate of the habitat types approximately $10 \mathrm{~cm}$. The material collected in core samples was dried at $400 \mathrm{C}$ for $24 \mathrm{hrs}$ and weighed. Material was then ashed for $3 \mathrm{hrs}$ at $550^{\circ} \mathrm{C}$. AFDW was considered to be representative of the organic fraction in the core sample.

Core samples were also taken in the main channel habitat to determine size distribution of sand particles. Collected material was washed clean of organics by elutriation technique and material was dried at $40^{\circ} \mathrm{C}$ for $24 \mathrm{hrs}$. Sand grains were sieved to four size fractions from which the percentage grain size was determined. Sand particles were sorted to $>2.5 \mathrm{~mm},<2.5 \mathrm{~mm}-600 \mu \mathrm{m}$, $<600 \mu \mathrm{m}-400 \mu \mathrm{m},<400 \mu \mathrm{m}-250 \mu \mathrm{m}$

At selected, representative habitat types, the temperature, dissolved oxygen (DO), and pH were monitored at $1 \mathrm{hr}$ intervals with the instrumentation described in section 1.

\section{Results}

Flood Plain Survey

The flood plain survey (Figure 2.2) showed that, in the past history of UTRC, the channel had changed positions several times, and had been located at various times on either side of the existing channel. 


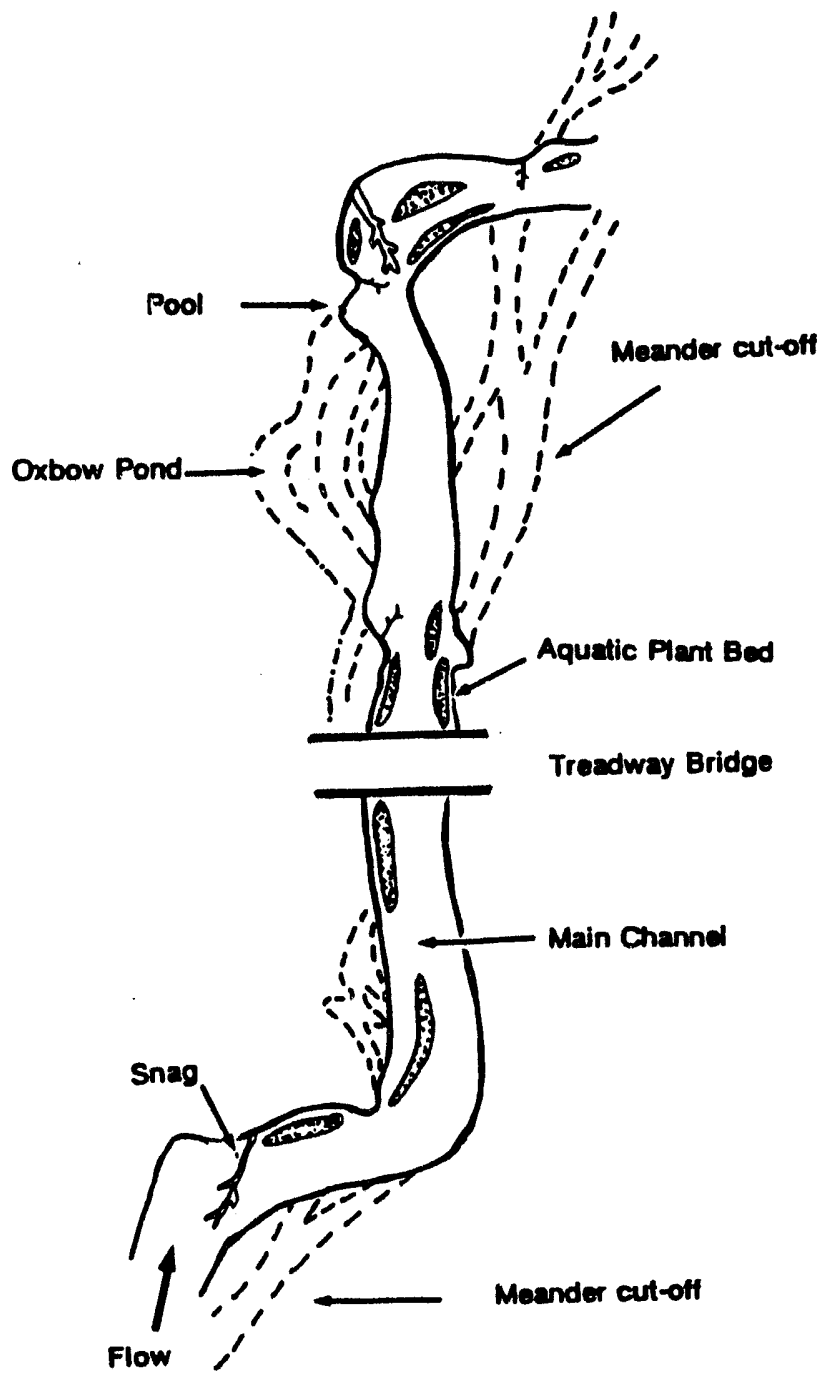

Figure 2.2. Map of study site on Upper Three Runs Creek, South Carolina showing the flood plain surrounding the channel. Dashed lines show the past locations of the stream channel. 


\section{Discharge Regime}

The predictability (P) of mean discharge in UTRC (Table 2.2) was found to be very high $(P=0.906)$. The ratio of the contingency to the predictability $(M / P)$ was very low (0.032) which indicates that the proportion of predictability due to seasonality was low. UTRC was predictable because it had a very constant flow $(C=0.877)$. The proportion of predictability due to constancy of discharge $(C / P)$ being high (0.968). Among 58 streams in the U.S. Geological Survey's National Hydrologic Benchmark Network, UTRC ranked second in flow predictability (Gurtz, pers. commu).

Table 2.2 Upper Three Runs Creek watershed characteristics and predictability of monthly mean, maximum and minimum stream discharge for years 1970-1983. Predictability indices are from Colwell (1974): $P=$ Predictability, $C=$ Constancy, $M$ = Contingency, and $M / P=$ proportion of predictability due to seasonality. $C / P=$ proportion of predictability due to constancy. UTRC discharge data were from U.S.G.S. site \# 02197300 , approximately $3.8 \mathrm{~km}$ upstream of the study site.

Drainage Area $=225 \mathrm{~km}^{2}$ Mean Discharge for $16 \mathrm{yrs}=3.08 \mathrm{~m}^{3} / \mathrm{sec}$

\begin{tabular}{lccccc}
\hline $\begin{array}{l}\text { Monthly } \\
\text { Average }\end{array}$ & $P$ & $C$ & $M$ & $M / P$ & $C / P$ \\
\hline Mean & 0.906 & 0.877 & 0.029 & 0.032 & 0.968 \\
Maximum & 0.750 & 0.714 & 0.036 & 0.049 & 0.951 \\
Minimum & 0.914 & 0.901 & 0.014 & 0.015 & 0.985
\end{tabular}




\section{Whole Study Area (WSA) Survey}

Striking differences were seen between the percentage of total surface area and creek bottom surface area occupied by each habitat type (Figure 2.3). Over $50 \%$ of the creek bottom area was occupied by the main channel region. Aquatic plants and pools made up $20 \%$ and $19 \%$ of the bottom area respectively. Snag material was primarily the result of trees which had fallen across or partially into the creek channel. Most snag material was cantilevered off the banks and was not in direct contact with the substrate. Thus, snag material represented $1 \%$ of the bottom surface area. Miscellaneous habitats were primarily side channels which accounted for $10 \%$ of the bottom surface area.

In comparison to bottom surface area, the aquatic plant beds had $64 \%$ of total surface area compared to the other habitat types and total surface area was more than three times the bottom surface area for plant beds. Main channel area represented $16 \%$ of accountable total habitat, one third of the percentage it represented for the bottom surface area. Snag surface represented $1 \%$ of bottom surface area, but $11 \%$ of total surface area.

\section{Quarterly Habitat Measurements}

\section{Similarity to Whole Study Area (WSA) Survey}

Habitat percentages found for the quarterly habitat measurements (Figure 2.4) showed trends similar to those of both bottom and total surface area for the WSA survey (Figure 2.3). Pools appeared to be under-represented in quarterly sampling and snags were slightly over-represented.

\section{Bottom and Total Surface Area}

Percentage of pool total surface area was less than percentage of bottom surface area and percentage of total surface area of snags was greater than the 


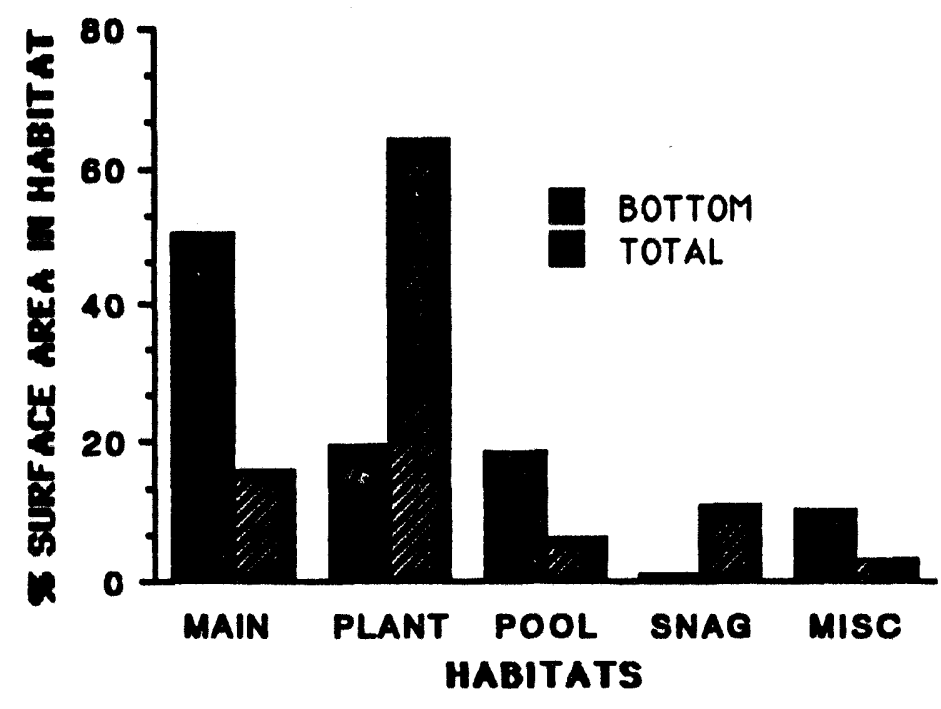

Figure 2.3. Percentage of UTRC bottom surface area and total surface area cocupied by each habitat type. Data from whole study area (WSA) survey, 10 sample sites were randomly selected within the $90 \mathrm{~m}$ long study area. 


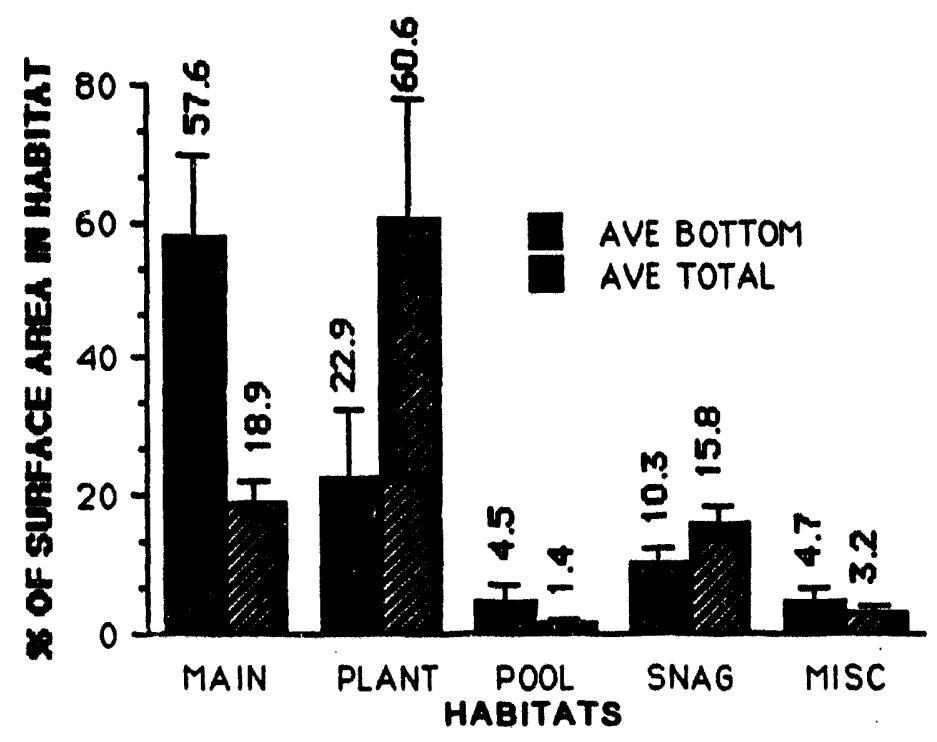

Figure 2.4. Mean percentage of UTRC bottom area and total surface area occupied by each habitat type (tSE). Data from quarterly stream survey, 8 sample sites were randomly selected within the $190 \mathrm{~m}$ long study area. 
percentage of bottom surface area (Figure 2.4). Comparisons between percentages of bottom surface area versus total surface area showed significant differences (ANOVA, $\alpha=0.05$ ) in all habitat types except the miscellaneous category. The percentage contribution of the bottom surface area of the main channel habltat type was 3 times that of the total surface area, and plant total surface area was 3 times greater than its bottom surface area.

The percentage of total surface area of aquatic plants $(61 \%)$ was significantly greater than percent surface area of all other habitat types. Also important to total surface area of the selected habitats was the main channel $(19 \%)$ and snags $(16 \%)$ which were not statistically different from each other but were different from other habitat types $(\alpha=0.05)$. The bottom surface area of the plant bed was significantly greater than that of all other habitat types (Figure 2.5).

\section{Differences between Sites}

Aquatic plants made up approximately $60 \%$ of the total surface area of the sampled habitat types and, because of their dominance, influenced the calculation of percentage surface area represented by all other habitat types. Some of the differences between sites in percentage of surface area can be appreciated by considering the surface area of the dominant species of aquatic plant located at that site (Figure 2.6). S. americanum had the greatest surface area during all seasons at site 8 . Seasonal occurrence was quite variable at other sites. P. epihydrus contributed most of the total surface area during all seasons at sites 2, 5 and 6. Site 4 did not have aquatic plants in the Spring. Site 8 was the most heavily shaded of all sites, and had the aquatic plant habitat composed almost entirely of $\mathbf{S}$. americanum. Sites 5 and 6 had the least canopy cover and probably received the greatest solar input. The percentage of surface area of $\mathbf{S}$. americanum was low at these sites. 


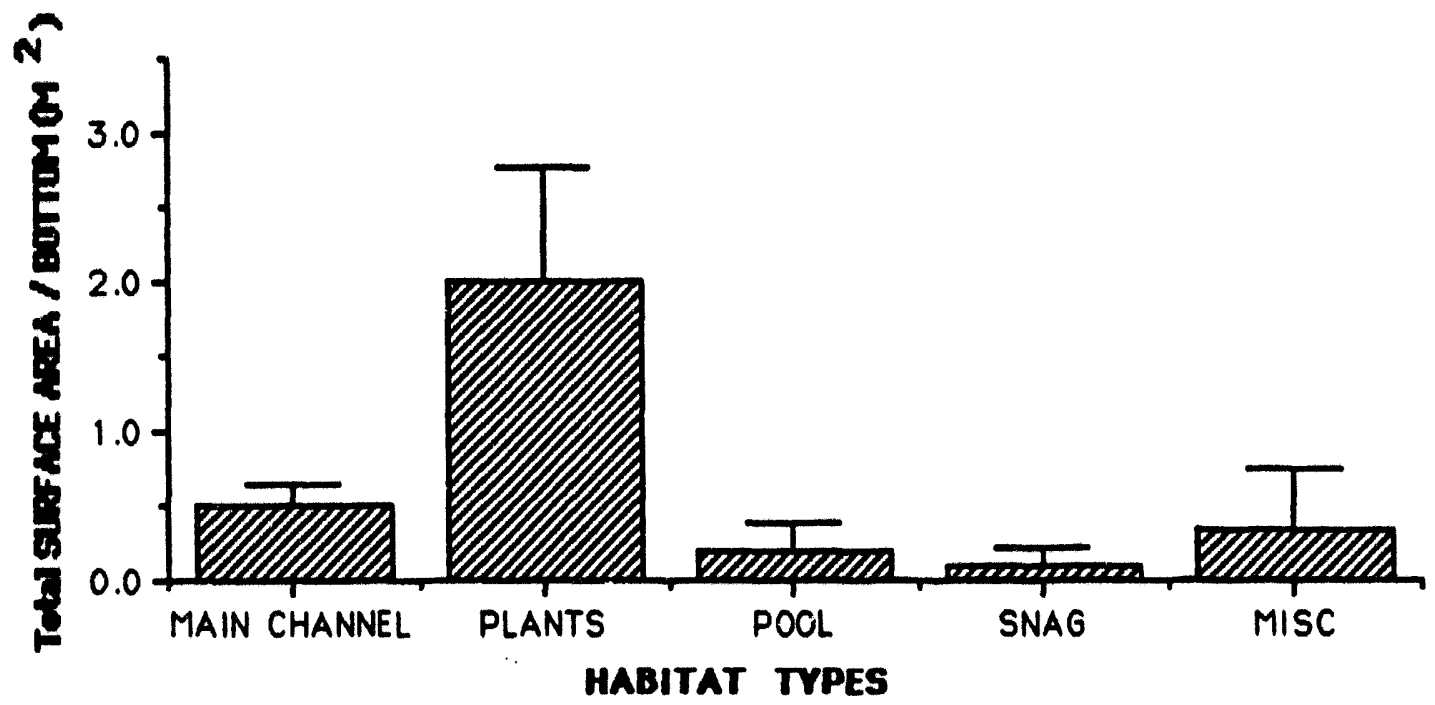

Figure 2.5. The dimensions of habitat type total surface area in $\mathrm{m}^{2}$ relative to the dimensions of bottom surface area in $\mathrm{m}^{2}$. 

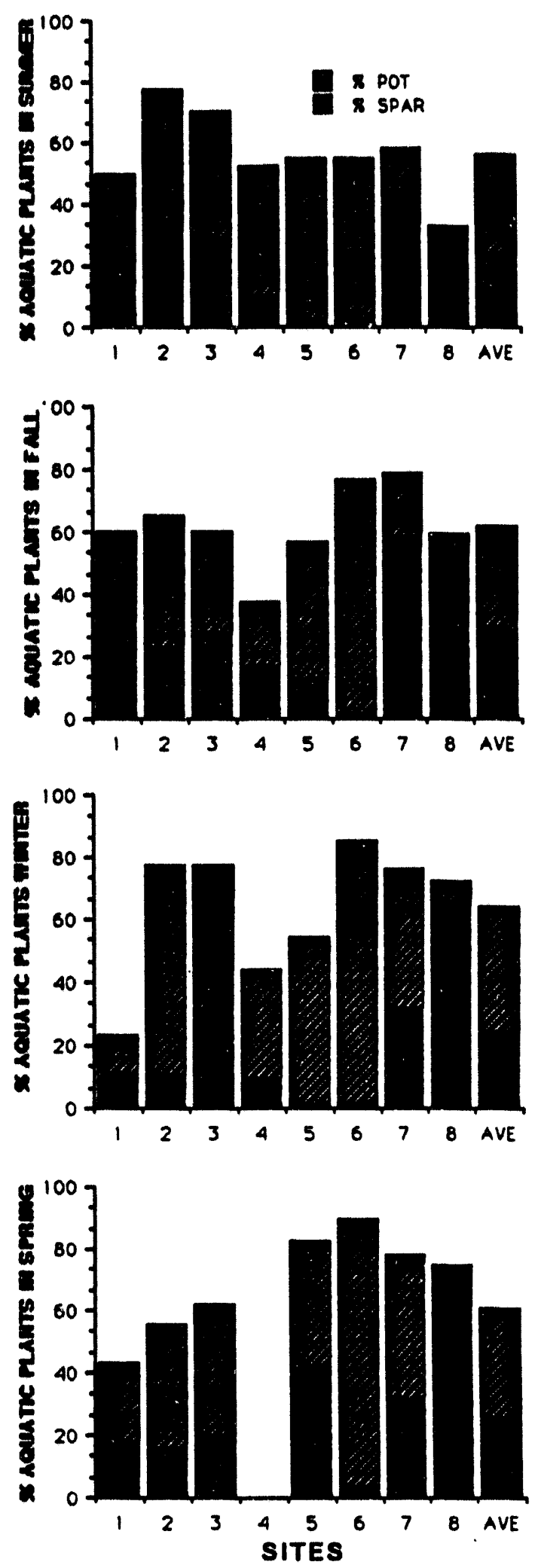

Figure 2.6. Mean percentage of total surface area occupied by the aquatic plants Sparganium americanum (SPAR) and Potamogeton epihydus (POT) and the percent composition of the aquatic plant species by site and season. 


\section{Differences between Seasons}

There were slight, nonsignificant, seasonal differences in the percentages of habitat types when all sites were averaged by season (Figure 2.7). Aquatic plants, the only living, and thus seasonally influenced, habitat showed some trends which might be associated with solar input. Since plants represent such a large percentage of all habitat types, relatively small changes in surface area in plants may override relatively larger percentage changes in other habitat types (relative importance within that habitat type).

Individual sites showed considerable seasonal variation in habitat type percentages of surface area (Figure 2.8). Aquatic plants had the greatest percentage of total surface area at most sites in all seasons. Apart from extremely high flow events which could remove aquatic plant beds and undercut banks causing trees to fall into the main channel as snags, little else is likely to have contributed significantly to the relative abundance of habitat types.

\section{Major Changes in Habitats}

A flood in the spring of 1984 altered the distribution of habitat percentages of total surface area in UTRC (Figure 2.9). Discharge increased from $2.44 \mathrm{~m}^{3} / \mathrm{sec}$ on May 25 to $4.64 \mathrm{~m}^{3} / \mathrm{sec}$ by May 27 then to an average of $6.45 \mathrm{~m}^{3} / \mathrm{sec}$ from May 28 to May 30. Following the flood, surface area of the main channel increased, while total surface area of aquatic plants and snags decreased. Pre- and postflood habitat percentages were not statistically different. However, site 4 (Figure 2.6) had all aquatic plant beds removed by scouring action. Apparently only site 4 was affected catastrophically by the high flow event.

In two separate incidents, large snag habitats were instantly created when terrestrial woody material entered the creek channel. Each occurrence altered the current velocity profile and channel morphology in different ways. 


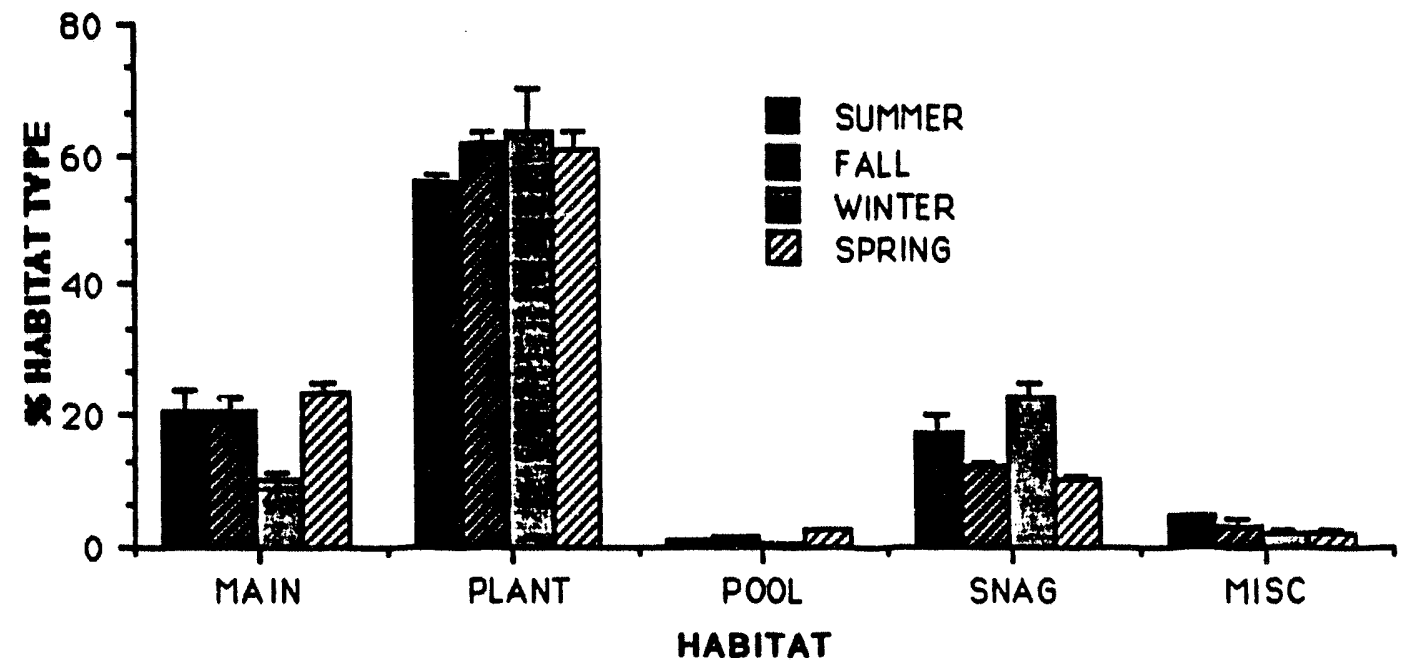

Figure 2.7. Seasonal average percentages of total surface area for habitat types when all 8 sites were averaged together. Shown are means and standard error bars. 

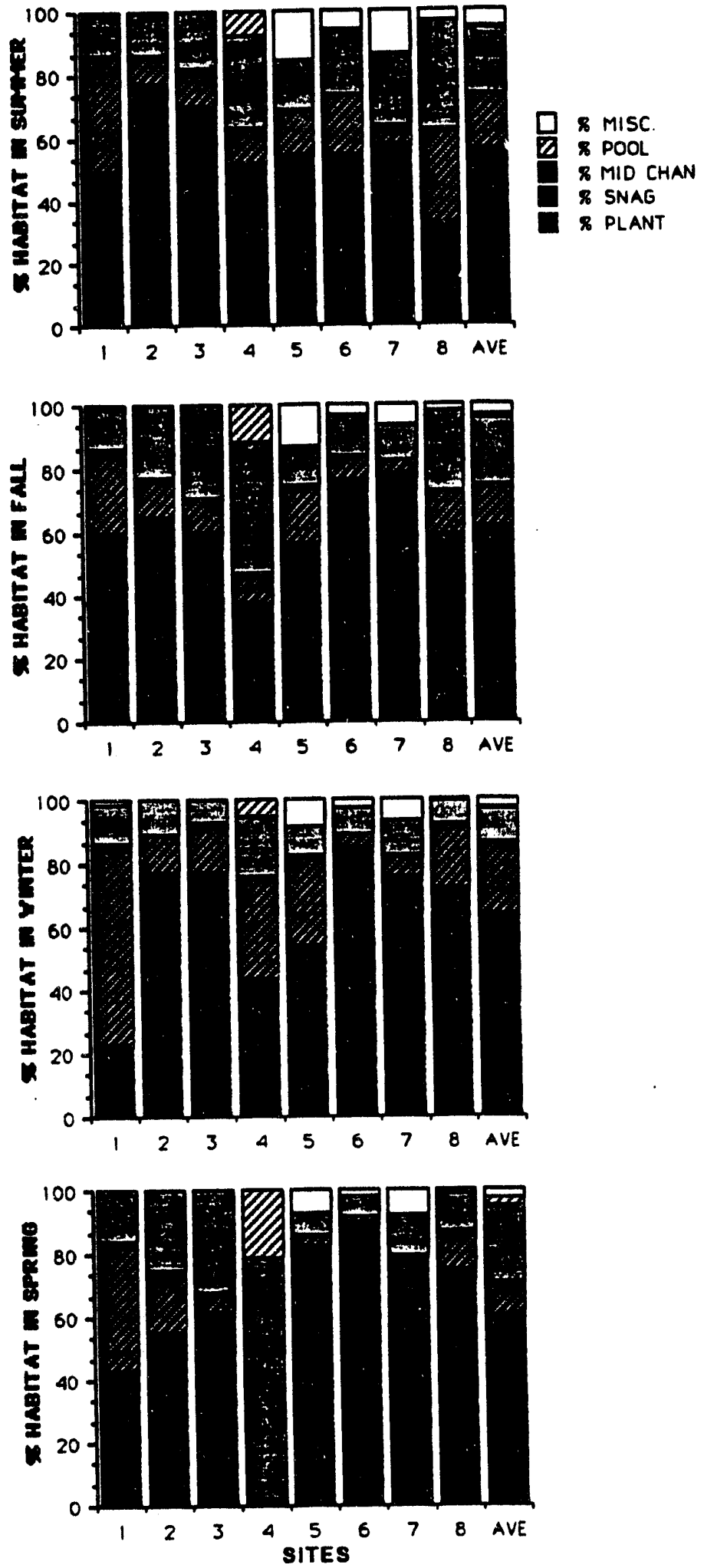

Figure 2.8. Seasonal averages in percentages of total surface area for each habitat type by site. 


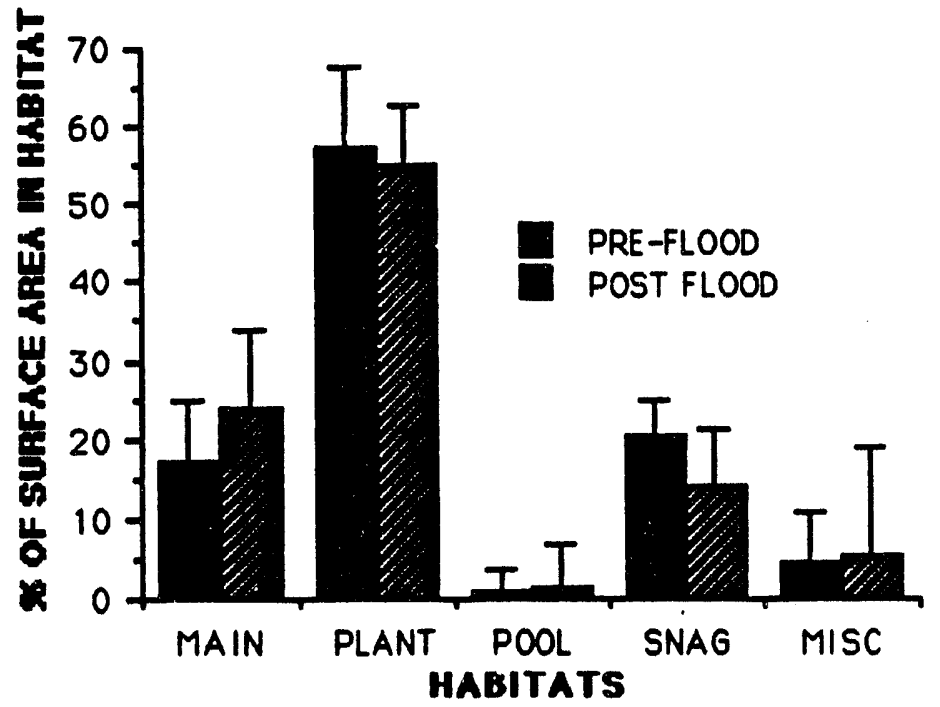

Figure 2.9. Mean percentage and standard error bars of the total surface area of each habitat type in April 1985 (pre-flood) and June 1985 (post-flood). Means were determined by pooling percentages from all sites. 
In November 1984, a large clump of water tupelo and willow oak fell into the creek channel at site 1. This newly developed snag altered the hydrologic regime both upstream, and downstream and at the position of inundation (Figure 2.10). The clump of vegetation which tipped into the channel was of sufficient size to partially dam the channel causing a widening of the channel surface upstream of the snag, although channel width at the snag did not change. Downstream of the snag, a meander cut-off no longer had flowing water and, for two months following the introduction of the snag, a small pool formed against the bank. Current velocity was also changed at this site. Prior to the new snag introduction, a small snag composed of root material was present. Greatest current velocity viras located $1.5 \mathrm{~m}$ from the bank just to the mid-channel side of the root material. Post-snag maximum current velocity was located 3 to $4 \mathrm{~m}$ away from the bank on the mid-channel side of the new snag. Prior to the introduction of the new snag, greatest channel depth was located below greatest current velocity and midchannel to the root-snag material. Following introduction of the new snag, greatest channel depth moved approximately $4 \mathrm{~m}$ from the snag side bank and was below the new site of maximum current velocity. Prior to introduction of the new snag, the structure of the old, root-snag material had decreased current velocity downstream and a small aquatic plant bed was present. Following the introduction of the new snag material, current velocity downstream of the snag was reduced by approximately $50 \%$ and within 2 months, the aquatic plant bed, located within site 1, had doubled in size and moved in position both upstream and toward the mid-channel. Downstream of the new snag, discharge profile and channel morphometry had also changed. Maximum current velocity in the channel increased and moved in position from just off the mid-channel side of the aquatic plant bed to an area closer to the opposite bank. Maximum channel depth was located below the area of maximum current velocity. Width of the 

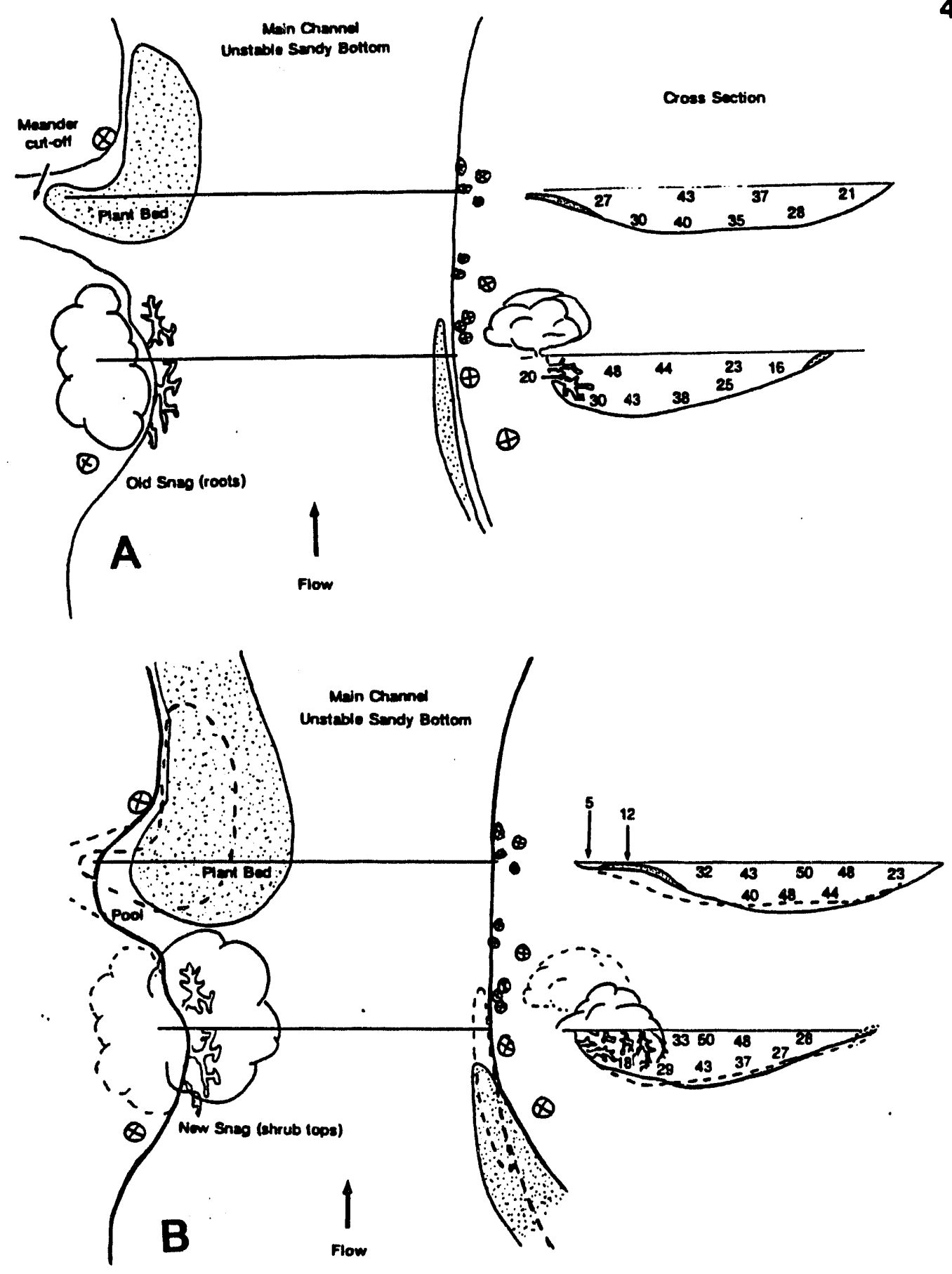

Figure 2.10. Map of UTRC site 1 showing the the locations of habitat types prior to introduction of a snag, $A$; and locations of habitat types two months after the snag had been in the channel, B. In A, snags and channel position are shown as solid lines. In $B$, dashed lines represent the pre-snag channel and plant bed positions. Stippled areas are plant beds and cross hatched areas are pools. Cross section shows current velocity and channel shape. 
creek water surface at, and just below, the new snag increased initially but returned to pre-snag bank position within 2 months.

The introduction of snag material into the channel at the upstream edge of site 8 in early July of 1984 caused a considerable change in habitat type distribution, but discharge profile and channel morphometry responded differently from that observed at site1 (Figure 2.11). The snag was the top of a large loblolly pine. The bank was approximately $0.5 \mathrm{~m}$ high on this side of the channel so that the tree tipped into the water with the tree top being deeper than the main trunk. As at site 1, the snag had a slight damming effect, and diverted the water both around the tree top and under the trunk portion along the bank. The channel widened at, and just below, the snag but never returned to the pre-snag bank position as at site 1. Current velocity profile was altered at the snag and was changed at two downstream sites. Current velocity nearly doubled and was highest below the snag and along the bank. Opposite the snag, current velocity along the new snag bank was lower than prior to the introduction of woody material and an aquatic plant bed formed here within two months. Behind the snag, highest current velocity was located in the middle area of the main channel. Farther downstream current velocity increased along the outside of the creek bend.

Creek morphology changed as the bank was slightly undercut and the bottom deepened at the snag. The aquatic plant bed located directly behind the snag decreased in size and moved downstream within 1 month. Within 2 months, the aquatic plant bed downstream and around the bend from the snag nearly doubled in size (Site 7). A pool habitat formed bank-side of the enlarged plant bed. 

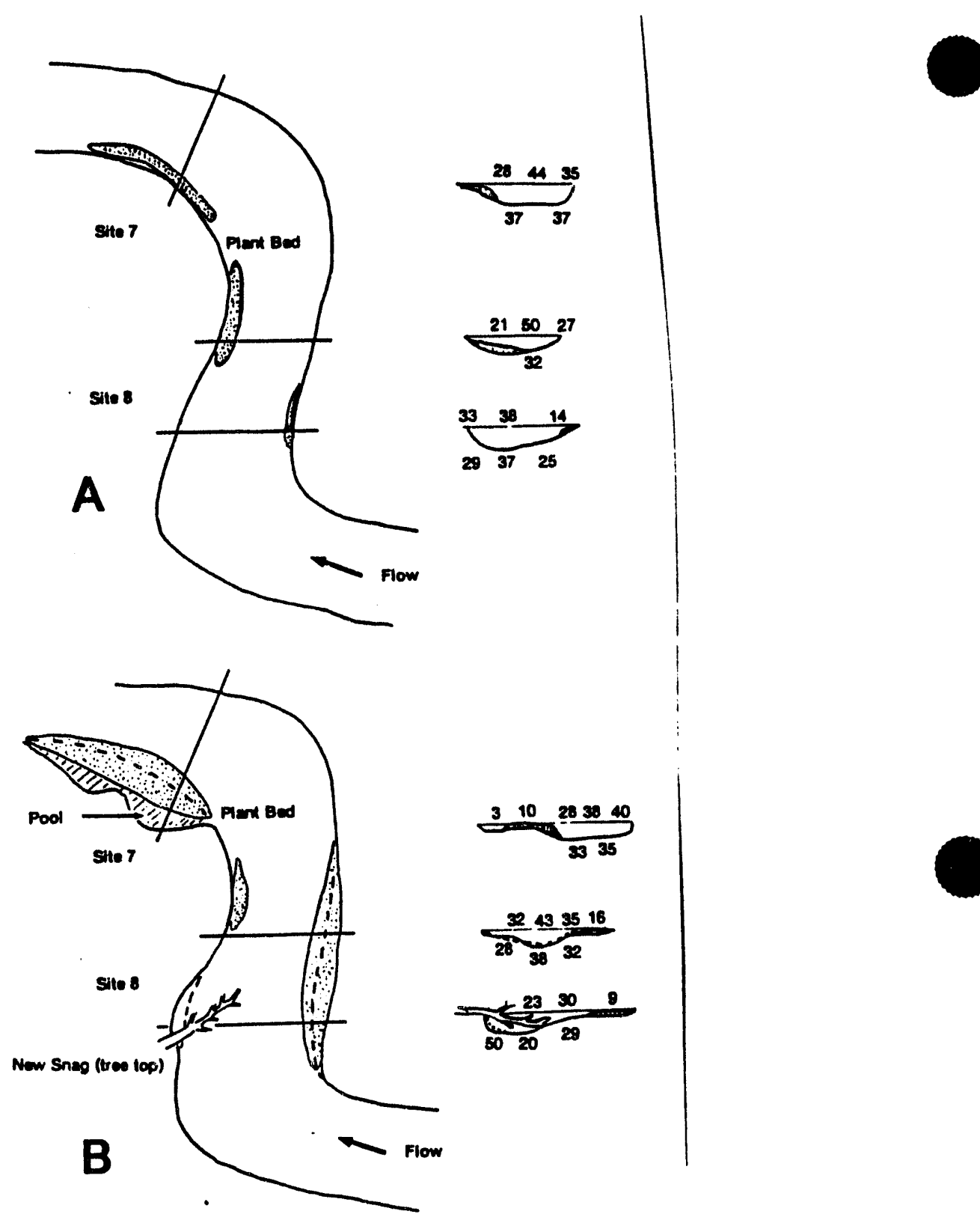

Figure 2.11. Map of UTRC site 8 showing the the locations of habitat types prior to introduction of a snag, $A$; and locations of habitat types two months after the snag had been in the channel, B. In A, snags and channel position are shown as solid lines. In B. dashed lines represent the pre-snag channel and plant bed positions. Stippled areas are plant beds and cross hatched areas are pools. Cross section shows current velocity and channel shape. 
Unique Characteristics of Habitats

Current Velocity by Habitat

The current velocity profile was unique for each habitat type (Figure 2.12). The main channel had the highest current velocity from top to bottom for all habitat types and showed typical velocity profile for a flume with a low bottom roughness factor (Statzner et al. 1988). The current velocity in the plant beds declined significantly with depth. The plant bed current profile was different from all other habitat profiles but current velocity at the top of the plant bed was not different $(\alpha=0.05)$ from the velocity of the main channel bottom or the snag bottom. Pool current velocities showed a similar pattern to plant current velocities and had the lowest average velocity (6.05 \pm 1.37$)$. The snag current velocity profile was the inverse of that shown by plant beds and pools. Current velocity at the bottom of the snag was not different from that of plant beds at the surface and main channel at the bottom. Average current velocity was greatest at the bottom of the snag habitat type.

\section{Standing Crop Biomass}

Mean standing crop biomass of plant material within aquatic plant beds was considerable and showed some seasonality (Figure 2.13). Standing crop biomass (g AFDW / $\mathrm{m}^{2}$ within plant beds) of $\underline{P}$. epihydrus was greatest in summer and least in spring. The seasonal pattern observed for $\mathbf{S}$. americanum was not statistically significant. In all seasons mean biomass of $P$. epihydrus was greater than of $\mathbf{S}$. americanum but there was much variability in weights and differences were not statistically significant.

Total mean standing crop biomass, adjusted to include surface area of all plant beds (g AFDW / $\mathrm{m}^{2}$ of plant " $\mathrm{m}^{2}$ bottom surface area of plant bed for the 8 sites in the study area) (Figure 2.14) showed a seasonal pattern different from 


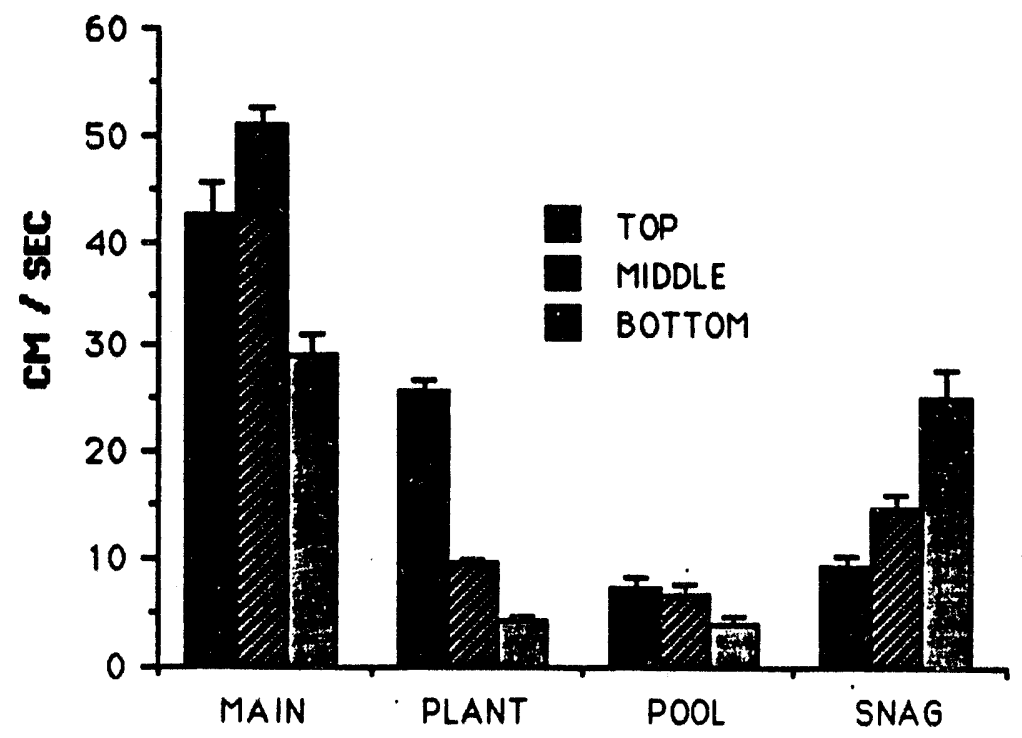

Figure 2.12. Mean current velocity plus standard error bars for the top, middle and bottom of the all habitat types. 


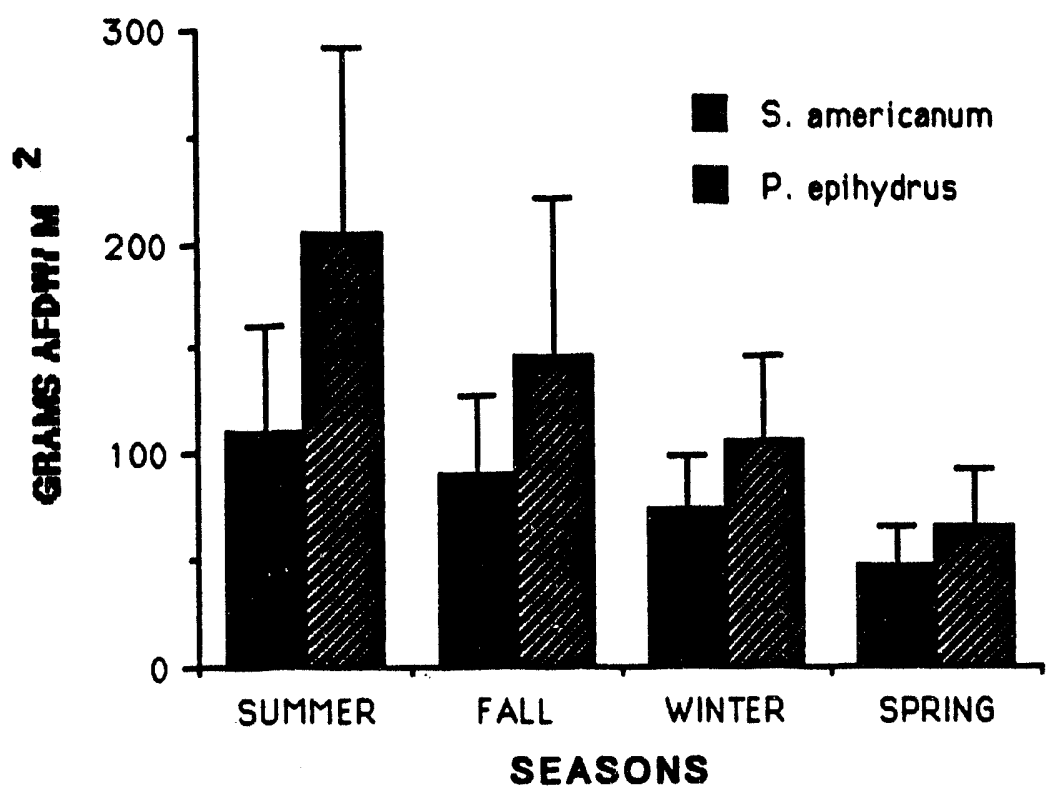

Figure 2.13. Mean standing crop biomass $/ \mathrm{m}^{2}$ of plant bed total surface area for dominant aquatic macrophytes by seasons. Provided are the grams AFDW biomass $/ \mathrm{m}^{2}$ and SE from samples within plant beds for Sparganium americanum and Potamogeton epihydrus. 


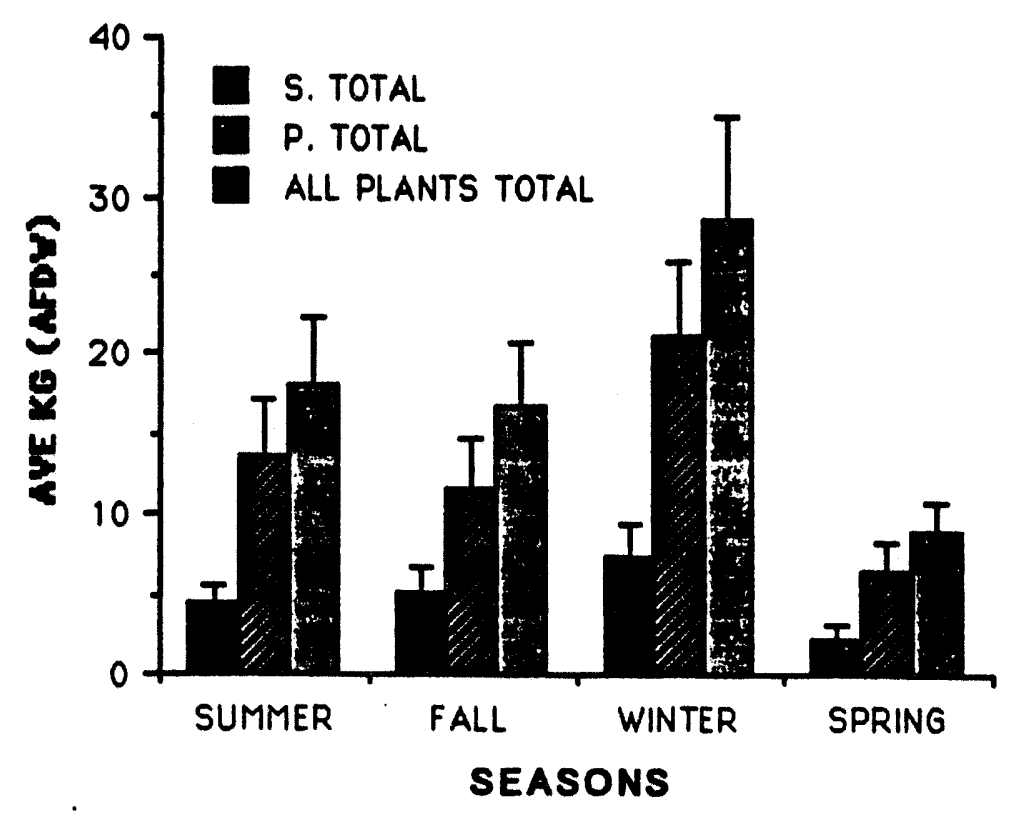

Figure 2.14. Total mean standing crop biomass, adjusted to include surface area of all plant beds ( $\mathrm{g}$ AFDW / $\mathrm{m}^{2}$ of plant " $\mathrm{m}^{2}$ bottom surface area of plant bed for the 8 sites in the study area). Provided are $\mathrm{kg}$ AFDW and SE of standing crops for Sparganium americanum. Potamogeton epihydrus, and plant material combined. 
biomass $/ \mathrm{m}^{2}$ within plant beds. For both dominant aquatic plants combined, winter had significantly greater total standing crop biomass and spring was significantly less than all other seasons. The greater total biomass is probably due to the slight seasonal differences in total plant surface area (Figure 2.7.) Biomass of $\mathbf{S}$. americanum and $\mathbf{P}$. epihydrus was statistically highest in the winter and lowest in the spring. Summer and fall seasons had similar biomass.

Total mean biomass adjusted to include surface area of all plant beds (Figure 2.14), showed $\mathbf{P}$. epihydrus was significantly greater than $\underline{\mathbf{S}}$. americanum in all seasons.

\section{Epiphutes and Detritus Associated with Macrophytes}

The AFDW of algae and detritus brushed from leaves of the two dominant aquatic macrophytes averaged $28 \mathrm{~g} / \mathrm{m}^{2}$. There were no differences in standing crop of epiphytes and detritus on $\mathbf{S}$. epihydrus compared to $\mathbf{P}$ americanum

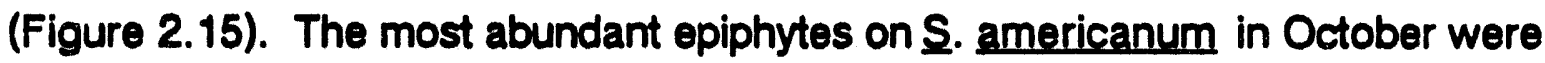
Rhodochorton violacea (Kuetz.) Ham., Batrachospermum macrosporum Mont., and a type of Stigoclonium. Diatoms were dominated by Eunotia sp.

\section{Iranspert Particulate Organic Maiter}

The average mg AFDW of suspended organic material (Figure 2.16) in transport (TPOM) was similar when collected at different depths in the water column. However, seasonal differences did exist (Figure 2.17). Spring had the statistically highest average TPOM, and winter had less $(\alpha=0.05)$ than all other seasons. The approximate average AFDW of organic carbon in transport was 3 $\mathrm{mg} /$ liter. Using the average discharge of $3.08 \mathrm{~m}^{3} / \mathrm{sec}$, approximately $796 \mathrm{~kg}$ of organic carbon passed through the study area each day. 


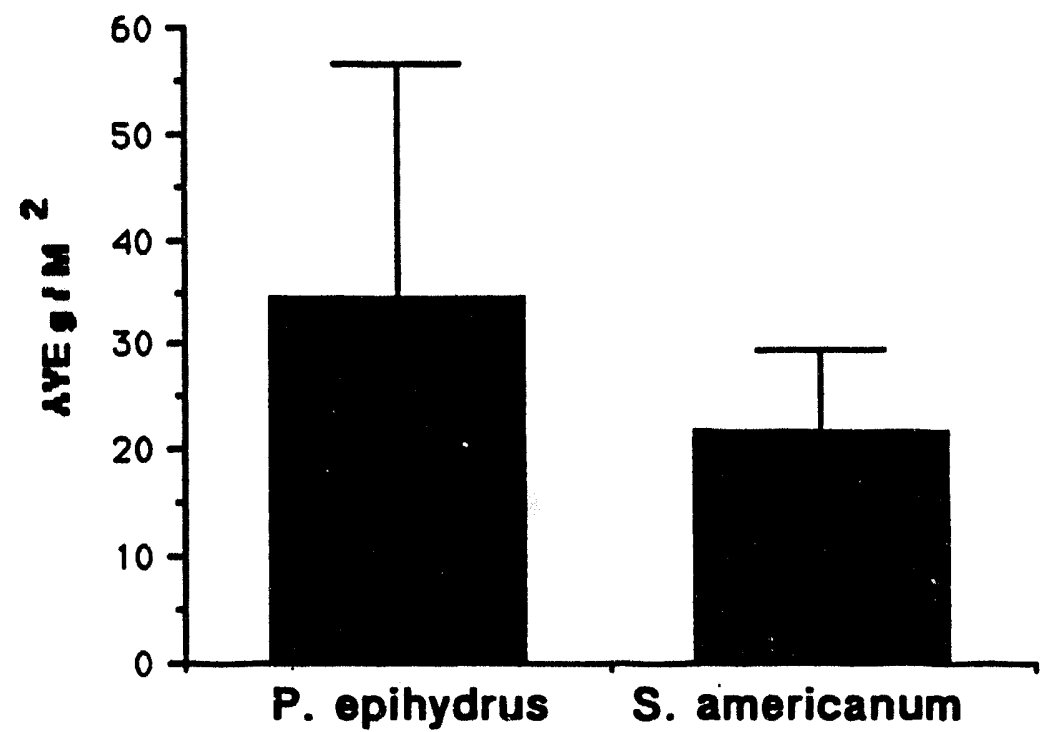

Figure 2.15. Mean standing crop biomass / $\mathrm{m}^{2}$ and SE of algae and detritus removed from aquatic macrophyte leaf surfaces. 


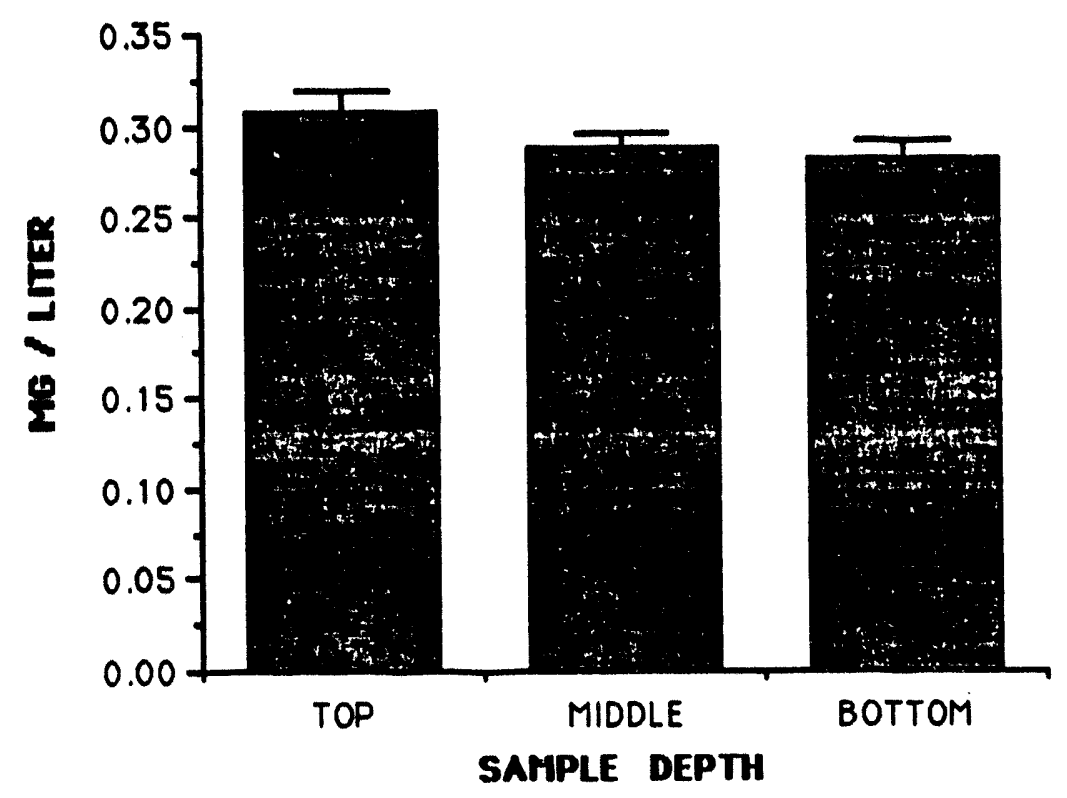

Figure 2.16. Mean standing crop biomass as $\mathrm{mg} / \mathrm{l}$ of transport particulate organic matter (TPOM) from UTRC collected by depth with all seasons combined. 


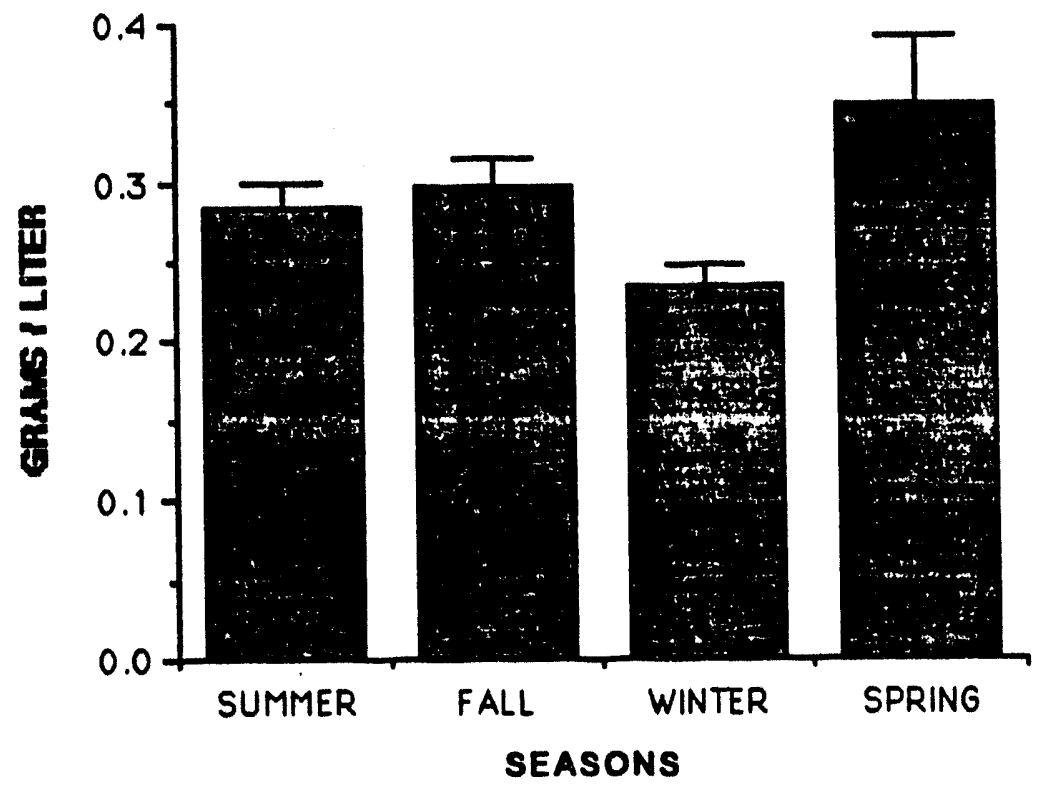

Figure 2.17. Mean standing crop biomass as $\mathrm{mg} / \mathrm{l}$ of transport particulate organic matter (TPOM) from UTRC collected by season with all depths combined. 


\section{Benthic Oroanic Matter}

Core samples collected in different habitats showed statistical differences in AFDW of BOM (Figure 2.18). Pool BOM was approximately twice that of plant beds. Plant beds had 10 times the BOM of mait s. The BOM in snag areas was highly variable and not differe . : -annel areas. A negative correlation $\left(R^{2}=-0.81\right)$ was found between current velocity at the bottom of each habitat type (Figure 2.12) and the amount of BOM deposition.

\section{Main Channel Sand}

Core samples of $500 \mathrm{ml}$ from the main channel substrate (Figure 2.19) showed most sand grains were between $2.5 \mathrm{~mm}$ and $600 \mu \mathrm{m}$ reflecting the relatively small, and heterogeneous particle size of the substrate.

\section{Discussion}

Habi s in UTRC: Why Are They Present and What Coi ineir Distribution and Relative Abundance?

\section{Habitat Types}

The distribution of habitat types within a river or stream is a function of the regional climate, geomorphology, and hydrologic regime of that system (Gurtz 1984, Minshall 1988). The climate dictates the amount and timing of both the precipitation and solar input. The precipitation interacts with riparian and aquatic vegetation (influenced by climate) and geomorphology of the basin to determine hydrologic regime. Hydrologic regime within the geologic restraints of the basin, determine the type and characteristics of the habitat types (Minshall 1988).

\section{Main Channel}

The main channel and banks of UTRC were composed primarily of unconsolidated sandy material. A general survey of the area (Figure 2.2) showed 


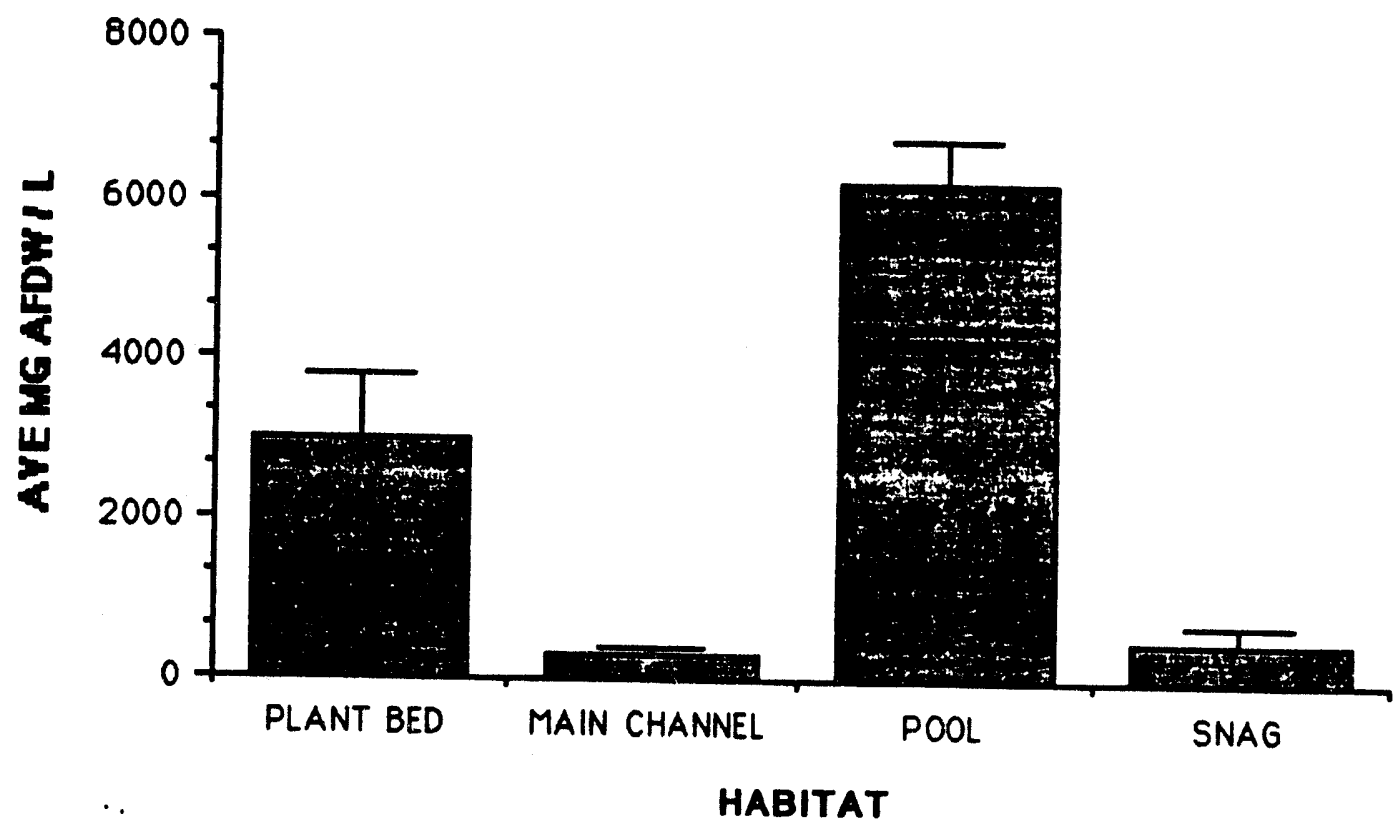

Figure 2.18. Mean biomass and SE of benthic organic matter (BOM) as $\mathrm{mg} / \mathrm{l}$, collected from each habitat type. 


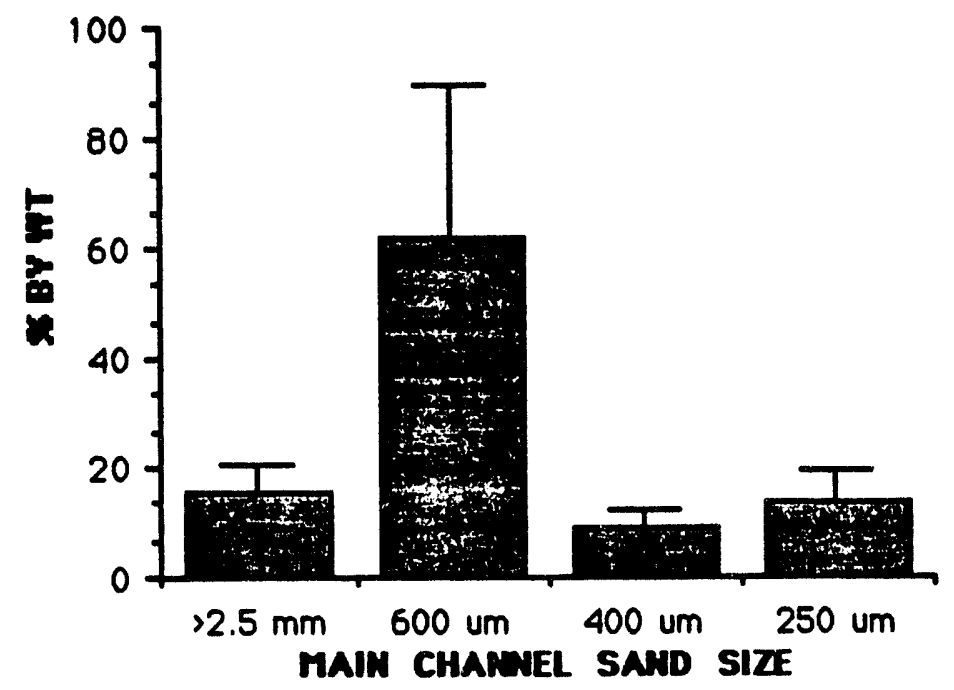

Figure 2.19. Percentage composition of sand by weight and SE that was retained by sieves of given sizes. Sand samples came from the main channel habitat type of UTRC. 
small oxbow type depressions, meander cutoffs and empty channeis which suggest the main channel had frequently changed position. Terrestrial vegetation, particularly trees, may have considerable influence on channel shape and position (Bisson et al. 1987). Because most of the UTRC bank was composed of sandy material and the creek was lined with a dense cover of shrubs and trees, the channel position appeared to be maintained to some extent by tree and shrub root structure. On two occasions terrestrial vegetation entered the main channel and altered habitat characteristics at the site and in slightly different ways. But on neither occasion was discharge abnormal and no direct cause was observed. Briefly, main channel morphometrics were altered at site 1 by deepening of mid-channel areas at snag locations, upstream damming of water, and shallowing, over time, behind the newly introduced snag habitat types. Morphometric alterations at site 8 were slightly different from those at site 1. At site 8 the channel widened around the inundated tree top. The main channel became deeper under the snag probably due to scouring effects of increased current velocity under and directly behind the snag. Current velocity profile was altered downstream of the introduced snags and probably caused changes in the distribution and abundance of downstream habitat types. In these examples, the position and relative abundance of the main channel habitat type, and other habitat types, changed both in space and with time.

\section{Aquatic Plants}

In UTRC the constant and predictable discharge (Table 2.2) appeared very important because it allowed the continuous growth of aquatic plant beds which comprised $60 \%$ of all habitat type surface. Comparison of UTRC discharge data collected from other Southeastern regional studies (Table 2.3) provided some possible causes for the occurrence of different habitat types, particularly aquatic 
macrophytes. Research conducted on the Satilla River, Georgia (Benke et al. 1984) showed that snags were very important to the overall macroinvertebrate production primarily because they were a stable habitat. Absence of aquatic plant beds, another type of stable habitat, was probably due to the discharge regime of the river and subsequent alteration of current velocity. In UTRC, snaginduced changes in current velocity profiles were sufficient to move and change the shape of aquatic plant beds. Thus, it may be assumed that the current velocity required to move an aquatic plant bed is less than that needed to move most snag material. Two years of discharge data on the Satilla River, Georgia showed a 100-fold change in discharge from a low of approximately $2 \mathrm{~m}^{3} / \mathrm{s}$ to a high of approximately $200 \mathrm{~m}^{3} / \mathrm{s}$. A change in discharge of this magnitude would probably be sufficient to scour any aquatic plant beds which began to developed. Smock et al. (1985) reported aquatic macrophytes in their study of Cedar Creek, SC. Three years of U.S.G.S. discharge data from Cedar Creek showed a 22fold difference between monthly means for minimum and maximum discharge. Discharge in UTRC had only a 4.4 fold increase in discharge over the three years of this study, with discharge ranging from $2 \mathrm{~m}^{3} / \mathrm{s}$ to $8.7 \mathrm{~m}^{3} / \mathrm{s}$. In the single observed incident that caused partial removal of a plant bed, discharge increased 2.6 times from a low of $2.4 \mathrm{~m}^{3} / \mathrm{s}$ to $6.5 \mathrm{~m}^{3} / \mathrm{s}$ in two days. The relationships between discharge, current velocity, and presence of aquatic plants may be related to plant type, root structure, root substrate composition, and the sheer forces that flowing water exerts on aquatic plants (Hynes 1970). These relationships are especially apparent downstream of hydroelectric dams where discharge regimes (seasonal and period-intensity) are altered to meet peak electrical-use demands (Ward 1967). Gurtz (1984) pointed out that timing and rate of change in discharge are more important than actual discharge rate. 
Table 2.3. Range of discharges and factor of change for UTRC (U.S.G.S.), Cedar Creek (Smock et al. 1985), and Satilla River (Benke et al. 1984).

\begin{tabular}{lrr}
\hline Stream & $\begin{array}{c}\text { Discharge Range } \\
\mathrm{m}^{3} / \mathrm{sec}\end{array}$ & Factor of Change \\
\hline UTRC, SC & & \\
Cedar Creek, SC & $20.00-8.70$ & 4.4 \\
Satilla River, GA & $0.23-5.10$ & 22.2 \\
& $2.00-200.00$ & 100.0 \\
\hline
\end{tabular}

The distribution of aquatic plants primarily along stream margins rather than in the mid channel regions was caused by current velocity. In mid channels, "shear stress" (Statzner et al.1988) is greater than the holding capacity of the root system. Gradual encroachment of the channel by aquatic plants is common (Hynes 1970) and was observed during late summer in UTRC. Subtle changes in hydrologic regime may not provide catastrophic destruction of aquatic plant beds, but can result in movement and changes in their size.

Solar input is another important abiotic factor determining the distribution of aquatic plants (Hynes 1970). Wave lengths and intensity of light will determine aquatic plant species occurrence, abundance, and growth form (Titus and Adams 1979). Effects of solar input on the distribution of aquatic plants was shown at three sites on UTRC. Site 8 was the most heavily shaded and $\mathbf{S}$. americanum made up $90 \%$ of all plant material collected at that site. Sites 5 and 6 were located next to Treadway Bridge and received very little shading and consisted of approximately $85 \%$ P. epihydrus. No quantification of riparian canopy cover other than observational notes was made at any site.

Current velocity and water depth have been shown to influence the size and form of aquatic macrophytes (Spence and Dale 1978, Hynes 1970). In UTRC, when the current velocity in plant beds of $\mathbf{S}$. americanum was less than 5 
$\mathrm{cm} / \mathrm{s}$ at the top of the water column, the emergent form of the species was present (Figure 2.11). In summer and fall, emergent vegetation soon bore fruiting bodies. Stems of emergent vegetation were much thicker than the ribbon-like structures occurring under flowing water. Emergent vegetation may have altered current velocity differently than non-emergent type vegetation. The plant material also provided a water-exiting structure other than snags and creek banks for use by emerging adult aquatic insects.

Pools

Pool habitat types were generally considered as depositional areas (Huryn and Wallace 1988) and retained the greatest amount of BOM (Figure 2.22), primarily because current velocity was the lowest relative to all habitat types (Figures 2.12, 2.15). Low current velocity resulted from physical obstructions to water flows. Obstructions that reduced current velocity were directly or indirectly related to channel form (stream meander or point bar), snags, or aquatic plant beds. At sites 4, 6, and 7 (Figure 1) pools were the result of point bars or a combination of bank form and aquatic plant bed. Pool habitat types were quite dynamic and were constantly being filled either with sand which was pushed up from the main channel or were overgrown with aquatic macrophytes. Often, pools were in a transition to becoming main channel or plant beds and were classified as miscellaneous. Consideration of the ephemeral nature of pools in this system may account for their under-representation in quarterly samples as compared to the whole stream sample.

\section{Snacs}

Snag habitats play unique, multiple roles in determining the habitat distribution and abundance. Snags alter current velocity (Figures 2.10, 2.11) and 
destabilize banks (Figure 2.11). If trees lining the main channel are of sufficient density and root strength to withstand the stream power, then the main channel may erode downward (Figure 2.10) to provide a sufficient energy release from hydrologic pressure (Leopold et al. 1964). If the channel erodes laterally, the bank and tree roots may become under-cut by the erosive forces of the current, and may cause a tree to fall into the main channel. Trees also may enter the channel by other means such as blow down, or logging). After the tree or shrub becomes a snag it may alter the current velocity and in turn affected the abundance and distribution of other habitat types, as demonstrated previously and shown in Figures 2.10 and 2.11. The main channel may widen or deepen, plant beds may enlarge and move toward the snag (Figure 10), or they may shrink and move away from the snag (Figure 2.11). Because snag habitat alterations of current velocity are sufficient to move aquatic plant beds (Figures $2.10,2.11)$, it may be assumed that snags have greater persistence than plant beds.

\section{Miscellaneous Habitat Types}

The category "miscellaneous habitat types" was developed to cover unusual habitats which were discovered during the term of this investigation. Among the interesting habitat types was the "meander cut-off" as described at site 1. These small riverlets (approximately $0.15 \mathrm{~cm}^{3} / \mathrm{sec}$ ) flow between sections of the main channel through densely forested areas. The water is extremely well shaded and the substrate is a mix of root surfaces, silt and sand. Meander cutoffs had intermittent flows during the term of study and may provide another unique habitat type or refugia for aquatic macroinvertebrates. 
Unique Characteristics of Each Habitat

Macroinvertebrates and Their Habitats

A multitude of unique habitat characteristics are selected by aquatic macroinvertebrates (Minshall 1984). Habitat selection by these organisms depends on the interactions of numerous physical and biotic factors. Organisms may respond positively or negatively to a given set of factors and optimal conditions may be different for each species and for different life stages of a given species. Some factors, such as water chemistry and dissolved oxygen, exert their effects on macroinvertebrate distribution universally. Other factors, most notably favorable current velocity, habitat type, substrate composition, and detritus distribution are patchy in distribution and as such are considered as potential causes of the heterogeneous distribution of macroinvertebrates (Reice 1974, Sheldon and Haick 1981, Barmuta 1989).

Each habitat type in UTRC had characteristics that provided unique properties, such as current velocity or detrital areas, that may have been attractive to the great diversity (650+ species of aquatic insects) of aquatic invertebrates that have been recorded from this creek (Morse et al. 1980,1983, Morse and Kelly 1982).

\section{Main Channel}

Within the dynamic main channel habitat, current velocity at the bottom was sufficiently high (Figure 2.12) and substrate size was so small (Figure 2.23) that only a small amount of BOM was deposited (Figure 2.22). Much research has been conducted on the relationships between substrate size and deposition of organic material (Minshall 1984 for review), which is assumed to be a primary source of energy for benthic macroinvertebrates. It is generally accepted that benthic organism abundance and biomass increase with increasing particle size 
(Ward 1975). Also, heterogeneous-sized substrates were found to be superior in the accumulation of particulate BOM, resulting in highest densities of aquatic benthic invertebrates (Hynes 1970). Research on sandy bottom substrates is quite limited. Barton (1980), Benke et al. (1984), and Soluk (1985) showed biomass in shifting sand areas was low relative to other habitat types but that because of high turnover rates (especially in the Chironomidae) production was quite high. Mackay (1977) found some Pycnopsyche (Trichoptera) larvae were dependent on a particular size of sand for case construction and also selected certain sand particle sizes in which to burrow during aestivastion.

\section{Aquatic Macrophytes}

Little aquatic macrophyte biomass is consumed as living plant material (McGaha 1952). Otto and Svensson (1981) argue that most aquatic plants produce secondary substances which reduce attacks by herbivores. This results in the energy stored in plant tissue being released into the system during senescence and decomposition, and utilized as detritus (Smock and Stoneburner 1980).

S. americanum biomass was greatest in summer and lowest in the spring. (Figure 2.17). Handoo and Kaul (1982) showed peak above-ground standing crop biomass for Sparganium ramosum Beeby was $874 \pm 200 \mathrm{~g} / \mathrm{m}^{2}$ in August (production averaged $4.7 \mathrm{~g} / \mathrm{m}^{2} /$ day). Although standing crop was lowest in the spring $\left(154 \pm 41 \mathrm{~g} / \mathrm{m}^{2}\right)$ production $\left(7.31 \mathrm{~g} / \mathrm{m}^{2} /\right.$ day) was highest at that time. Application of production equations from Handoo and Kaul (1982) showed summer production for $\underline{\mathbf{S}}$. americanum by site may average $0.24 \mathrm{~g} / \mathrm{m}^{2} /$ day and spring production could be $0.46 \mathrm{~g} / \mathrm{m}^{2} /$ day (Table 2.4). Production by $\underline{P}$. epihydrus was estimated from values for $P$. richardsonii developed by Cattaneo and Kalff (1980). Application of their production equations to my data showed 
production in UTRC ranged from 1.1 to $3.6 \mathrm{~g} / \mathrm{m}^{2} /$ day. Total macrophyte production was estimated to be between 1.34 and $4.7 \mathrm{~g} / \mathrm{m}^{2} /$ day.

Table 2.4. Estimates of primary production in UTRC from aquatic macrophytes Sparganium americanum and Potamogeton epihydrus, from all epiphytes, and from TPOM moving through the system.

\begin{tabular}{|c|c|c|c|}
\hline Taxa / Habitat & $\begin{array}{l}\text { Standing Crop } \\
\mathrm{g} / \mathrm{m}^{2} \text { (SE) }\end{array}$ & $\begin{array}{l}\text { Production } \\
\mathrm{g} / \mathrm{m}^{2} / \text { day }\end{array}$ & Reference \\
\hline $\begin{array}{l}\text { S. americanum } \\
\text { P. epihvdrus }\end{array}$ & $\begin{array}{rr}80.5 & (23.1) \\
130.4 & (59.5)\end{array}$ & $\begin{array}{l}0.24-0.46 \\
0.60-1.10 \\
1.10-3.60\end{array}$ & $\begin{array}{l}\text { Handoo and Kaul (1982) } \\
\text { Cattaneo and Kalff (1980) } \\
\text { Cattaneo and Kalff (1980 }\end{array}$ \\
\hline $\begin{array}{l}\text { Macrophyte } \\
\text { Totals (max) }\end{array}$ & 210.9 & $1.34-4.70$ & Estimated from UTRC Data \\
\hline Epiphytes & $28.5 \quad(17.0)$ & $\begin{array}{l}0.42-0.84 \\
0.67\end{array}$ & $\begin{array}{l}\text { Lamberti and Resh (1983) } \\
\text { Cattaneo and Kalff (1980) }\end{array}$ \\
\hline $\begin{array}{l}\text { Estimated } \\
\text { Totals }\end{array}$ & 239.4 & $1.76-5.54$ & Estimated from UTRC Data \\
\hline $\begin{array}{l}\text { Movement } \\
\text { TPOM }\end{array}$ & & $796 \mathrm{~kg} / \mathrm{da}$ & Estimated from UTRC Data \\
\hline
\end{tabular}

In sandy-bottomed creeks such as UTRC, aquatic macrophytes provide the majority of stable substrate (Figure 2.4) to which aquatic organisms can hold and maintain position in the current. The importance of stable substrate has been addressed by Benke et al (1984), and Reice (1985). The introduction of macrophytes has been shown to have significant effects on invertebrate community structure, feeding guild structure and microdistribution of organisms (Gregg and Rose 1985).

Macrophytes significantly alter conditions of current velocity (Figures 2.12,2.14) and, in so doing, influence the deposition of detritus (Figure 2.22). 
Because these factors are of prime importance to macroinvertebrate distributions in streams, macrophytes should have significant influences on macroinvertebrate distribution and abundance (Minshall and Minshall 1977, Rabeni and Minshall 1977. Gregg and Rose 1985).

Living structural material of aquatic macrophytes provides a spectrum of environmental resources that may be attractive to aquatic macroinvertebrates. Leaf structure itself provides a surface to which organisms cling or attach feeding apparatus and pupation structures (Hynes 1970). The structure of plant stems cause a stepping down of current velocities from which organisms can select favorable sites. This is an aspect which can be especially important to filter feeding organisms (Minshall 1984). The alteration of current velocity by aquatic plant beds results in the sorting of organic matter from the drift (TPOM) into the plant bed which serves to retain the BOM for use by members of the shredder and collecter-gatherer feeding groups (Cummins 1973). Also, aquatic plant surfaces function as a substrate upon which epiphytes grow (for use by scrapers) and probably function to sort very fine particulate organic matter (FPOM) and drifting diatoms from the water column.

\section{Epiphytes and Detritus Associated with Macrophytes}

The epiphytic community, in a broad sense, is the algae that grows on the surfaces of other substrates (aquatic plants, snags, rocks, sand particles, etc.) and the associated diatoms, bacteria and detritus which accumulates in this matrix (collectively called "autwuchs" or periphyton [Hynes 1970]). Epiphytes are readily accessible to macroinvertebrates with mouth parts morphologically adapted to grazing and scraping material (Cummins 1973). Although aquatic macrophyte production contributes to the food supply of herbivores and detritivores only late in the late season, epiphyte production is available throughout the year (Cattaneo 
and Kalff 1980). The relative contribution of epiphyte production to total production in a macrophyte bed is substantial. The production of epiphytes changes with the species of macrophytes upon which they grow, macrophyte morphology, depth of plant bed, season, and quality of the water. Caitaneo and Kalff (1980) found epiphyte production contributed up to $62 \%$ and $30 \%$ of the total primary production in beds of Myriophyllum spicatum Fernald and Potamogeton richardsonii Benn. respectively. The amount of algal and bacterial production found on artificial substrates in streams was found to be affected by grazing caddisflies (Lamberti and Resh 1983). Production to biomass ratio for periphytic material was 0.12 on grazed plates and 0.06 on plates excluded from grazing. A rough estimate of epiphytic production (Table 2.4) from these ratios suggested that production in UTRC could range from $0.42 \mathrm{~g} / \mathrm{m}^{2} /$ day to $0.84 \mathrm{~g} / \mathrm{m}^{2} /$ day. Estimates of epiphytic production by methods of Cantaneo and Kalff (1980) was $0.67 \mathrm{~g} / \mathrm{m} /$ day. Mclntire (1973) showed that small standing crops of periphyton were capable of supporting large standing crops of consumer organisms due to the rapid turnover rate of algae and bacteria in comparison with slower turnover rates of animals.

\section{Snags}

Anderson et al. (1978), and Dudley and Anderson (1982) have associated numerous species with wood substrates. Because wood is low in nutrient quality, few aquatic organisms are obligate xanthrophages (see Dudley and Anderson 1982, Anderson et al. 1984 for exceptions). Wood substrates have been recognized as major aquatic habitat types of considerable importance, especially in larger rivers (Sedell et al. 1982, Benke et al. 1984). In UTRC, snags did not form debris dams, and did not function to store rganic matter as has been shown in other systems (Smock et al. 1989, Trotter 1990). In UTRC snags were 
important because they are a stable substrate which may be used for attachment sites, pupation sites, refugia, and a source for materials for case construction by caddisflies. In the Southeast, high invertebrate production (especially of filterfeeders) on snags has been demonstrated by Cudney and Wallace (1980) and Wallace and Benke (1984). Snags, like aquatic macrophytes, provided an array of current velocities from which organisms can choose.

\section{Conclusions}

The basin formation of UTRC is primarily sand and is unstable as a habitat for macroinvertebrates. Because the discharge is quite constant and highly predictable, aquatic macrophyte beds develop. Along with the snags, aquatic macrophytes provide the only stable substrates in the stream. The aquatic macrophytes function as a food resource following senescence, but, prior to lysis, alter current velocity and distribution of benthic organic matter. Macrophytes also provide a substrate for the growth of epiphytic algae and associated bacteria and detritus. Macrophytes, in response to solar input, are responsible for primary control of diel patterns in dissolved oxygen and pH in the creek.

Snags alter current velocity and channel morphometry. In this process, snags control the distribution and abundance of aquatic plant beds. The position, depth and width of the main channel habitat type appears to be controlled by the interactions of snags and aquatic plant beds and their subsequent influence of hydraulics.

Pools are areas where the effects of gravity on the lateral movement of water have been nearly neutralized. Pools were short-lived in UTRC and were either incorporated into the rnain channel or overgrown by aquatic plants.

Because of its control over plant bed development and maintenance, the environmental variable that may exert primary control of habitats in UTRC is 
discharge and any alteration of the existing predictable, constant discharge regime (natural or anthropogenic) will change this system.

Each habitat type provided a unique combination of chemical, physical and organic resources from which potential and existing inhabitants could select. Past experience has shown that the distribution of organisms within stream boundaries is dependent upon how specific resources are distributed (Minshall 1984). If this is the case, then Southwood's (1977) proposition that habitats are the templates for ecological strategies is appropriate for UTRC. 
SPATIAL AND TEMPORAL DIFFERENCES IN AQUATIC INVERTEBRATE COMMUNITY STRUCTURE OF A BLACKWATER STREAM

\author{
IN THE SOUTH CAROLINA SANDHILLS
}

\title{
Introduction
}

Two previous aquatic insect faunal surveys of Upper Three Runs Creek (UTRC) (Morse et al. 1980, 1983, Morse and Kelley 1982) have shown this unpolluted, South Carolina, Sandhills stream to be extremely rich in species (650+). Comparisons of faunal surveys conducted in 1976-77 and that of 197980 (Morse and English 1984) showed major taxonomic shifts. These findings, though based on qualitative sampling techniques, are supported by quantitative studies showing temporal shifts in community structure (e.g., Vannote et al. 1980. McElravy et al. 1989). Along with analysis of the taxonomic structure of invertebrates in UTRC the functional feeding group percentages (Cummins 1973, 1977, Merritt and Cummins 1984) were determined for each survey period. Comparisons between years, of the functional feeding group percentages showed no changes. Because functional feeding group perceritages are believed to be a response to available food resources (Cummins and Klug 1979), these early data suggested that although food resources remained fairly stable, species having similar feeding strategies may replace each other through time. These temporal changes in species composition may cause problems with community structural indices which are used to measure water quality.

Recent studies have shown how stream hydrodynamics can effect macroinvertebrate distribution in bottom substrates (Barmuta 1989, Statzner et 
al. 1988, Minshall 1984). If organisms are moving in both space and through time, an accounting of this movement is a necessary first step in the accurate use of community structural indices in assessing water quality.

Objectives of this research were: (1) to determine if there were spatial or temporal changes in the macroinvertebrate community structure in UTRC, and, if there were, and (2) to assess these effects of the changes on water quality indices (which are based on community structure measurements).

\section{Methods and Materials}

Site Description

The site was located on UTRC which is situated in the U.S. Department of Energy's Savannah River National Environmental Research Park near Aiken, South Carolina. UTRC is a sandy-bottomed, third-order, blackwater stream. A more thorough description of the site including measures of discharge, physical and chemical information and habitat specific information is provided in sections 1 and 2.

Field and Laboratory Methods

Macroinvertebrate sampling was conducted monthly in preselected habitat-types, at 8 sites located near Treadway Bridge on the Savannah River Site (SRS). These habitats included the sandy main channel, aquatic plant beds of Sparoanium americanum Nuttall and Potamogeton epihydrus Rafinesque, pools, and snag-type habitats.

Sampling methods varied according to inabitat type, but all sampled material other than core sample, was collected with $0.5 \mathrm{~mm}$ mesh netting. The sandy bottom of the main channel was sampled with a $3.3 \mathrm{~cm}$ diameter PVC coring device. Aquatic plant beds were sampled with two different methods. 
Whole plants were removed from $25 \mathrm{~cm}^{2}$ of the plant bed bottom. Organisms collected by this technique were considered to occur in the plant habitat. To collect invertebrates which might drift from the plant material during sampling, a $0.5 \mathrm{~mm}$ mesh net was placed downstream of the collection site. A deep pool of organic material was located within the plant beds (see section 2), and was sampled by pulling a small ( $5 \mathrm{~cm}^{2}$ opening) dip net between plant stems for a distance of 10-25 cm. Each sample consisted of a pooling of several small dips so that $125 \mathrm{~cm}^{2}$ of substrate were sampled. Organisms collected in these samples were considered to occur in the benthic habitat. A third habitat type designated as plant bed included all organisms collected in the benthic habitat and an estimate of organism abundance if all plant material growing from a $\mathrm{m}^{2}$ of the benthic habitat were included. One $\mathrm{m}^{2}$ of bottom yields approximately $9 \mathrm{~m}^{2}$ of plant material. Pools were sampled with the same device used in the plant beds, and for the same surface area. Snags were sampled by removal with tree limb pruning shears. A net was placed downstream of the snag during snag removal and organisms drifting from the snag were added to the sample. All samples were preserved in the field with $37 \%$ formaldehyde and taken to the laboratory for removal of macroinvertebrates.

In the laboratory, macroinvertebrates were removed from the main channel sand primarily by elutriation. Plant material was washed and picked clean of aquatic organisms and total length of plant material was determined so that organism density could be established from methods described in section 2. Benthic and pool material was picked by hand under bright light. Snag material was washed, loose bark removed and material was picked by hand. Snag surface area was determined by methods described in section 2. Organisms were identified to the lowest possible taxonomic level using appropriate keys. Primarily those of Merritt and Cummins (1984) and Brigham 
et al. (1982). Voucher specimens are properly preserved, labeled and deposited in the Clemson University Arthropod Collection.

Organism abundance was determined on a $\mathrm{m}^{2}$ unit of area of a single plane for each habitat type except plant beds. Material from the plant beds was handled differently because the plant beds have both leaf surface area and bottom surface area, and so are multi-dimensional. The density of macroinvertebrates in main channel, plant, pool, sang and benthic habitats was determined on the bases of a two-dimensional plane, and could be compared directly to each other. Plant bed habitats were included to show the importance of additional surface area. Densities of organisms in habitats at each of the 8 sites, were pooled and used as replicates from which yearly average statistics were determined and used to test for differences among habitat types and between years 1984 and 1985. Average annual taxa richness was determined by including taxa from all sites on each sample date by habitat type. Taxa counts by dates were used as replicates.

Several biological indices used in assessing water quality were calculated for each sample. The Shannon-Weaver index of species diversity (Wilhm and Dorris 1968), the Biotic Index (Lenat et al. 1980), and the count of Ephemeroptera, Plecoptera and Trichoptera (EPT) (Lenat 1988) were modified and applied to the data. A ratio of EPT to all other taxa was used, rather than the EPT counts alone, because of the low average number of organisms collected from small quantitative samples. The recommended sampling technique used for application of EPT counts (Lenat 1988) is a timed survey of all available habitat types that generally yields many organisms. The use of an EPT ratio should adjust EPT counts to the total number of organisms collected. Taxonomic comparisons were made among aquatic invertebrates between habitat types to assess spatial differences. Taxonomic comparisons were 
made among aquatic invertebrates between years sampled to assess temporal differences. Comparisons were made by the percent-similarity index of Perkins (1983). The Percentage Similarity Index shows how many taxa occur in common between the two units being compared.

Organisms were grouped according to their morphological adaptation for gathering food (i.e., functional feeding groups of Merritt and Cummins, 1984). Feeding group proportions reflect the food resource composition available to macroinvertebrates in a given section of a stream. A listing of collected taxa, their biotic index pollution tolerance values, and functional feeding group placement are provided in Appendix C.

Single factor analysis of variance (ANOVA) was used to test for differences among habitat types, seasons and years. Sarnple sites were the replicates for tests among habitat types within seasons and within years. Least significant difference tests (LSD) were applied to density, taxa richness, and biotic index data to determine where the differences lie $(\alpha=0.05)$. No statistical tests were run to detect differences in diversity values. Tests for differences in EPT ratios and functional feeding group proportions were accomplished using ANOVA on the data which was arcsine transformed (to normalize) from the square root of each proportion. Coefficient of variation (CV) was used to determine variability in the data. High CV reflects high intersample variation which probably results from the non-random distribution of macroinvertebrates (Zar 1974). 


\section{Results}

\section{Spatial Variability}

\section{Oraanism Density}

The density of organisms per $m^{2}$ (Figure 3.1) was significantly different for all habitat types except for pools and snags which had similar low densities. The plant bed habitat had three times the density of macroinvertebrates of any other habitat because plant beds have a total surface area based on a bottom surface measure and total plant surface area present in a $\mathrm{m}^{2}$ of bottom. The main channel habitat had significantly higher organism density than all other single plane habitats. Chironomidae larvae made up $94 \%$ of the main channel fauna. Plant stems had greater densities of organisms than the benthic habitat, and benthic densities were greater than those of pools and snags.

\section{Taxa Richness}

Macroinvertebrate taxa richness in the main channel and pool habitats were low, and not statistically different from each other (Figure 3.2). Plant stems and benthic habitats had similar taxa richness and had the greatest taxa richness of single plane habitats. Taxa richness in snags was intermediate between these two groups. Pooling plant stem and benthic taxa caused the greatest taxa richness and showed the importance of the aquatic plant bed to overall taxa richness.

\section{Diversity Index}

Average annual diversity index values for invertebrate collections from channel, plant, pool, and snag habitat types were low and not significantly different from each other (Figure 3.3). Diversity values for organisms from the benthic habitat were greater than all others, and those from plant beds were 


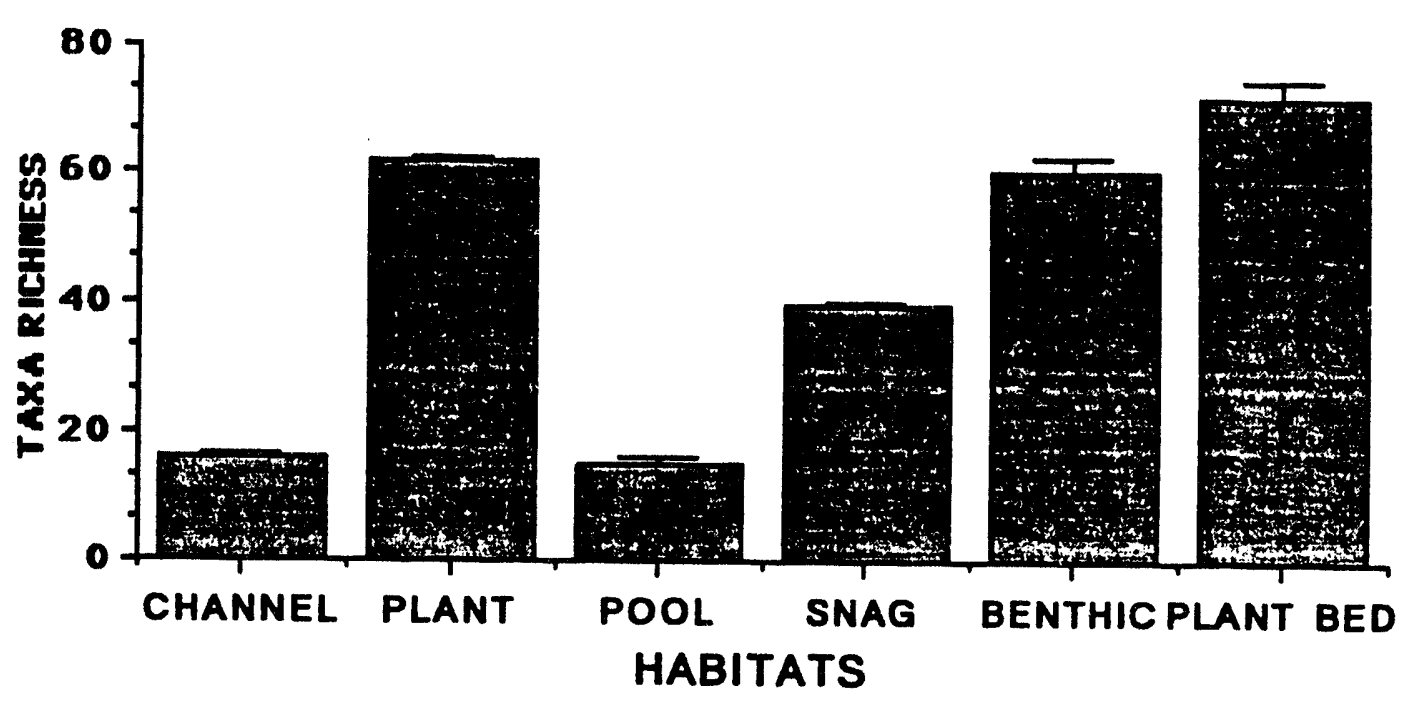

Figure 3.2. Average annual taxa richness ( $t$ SE) among habitats.

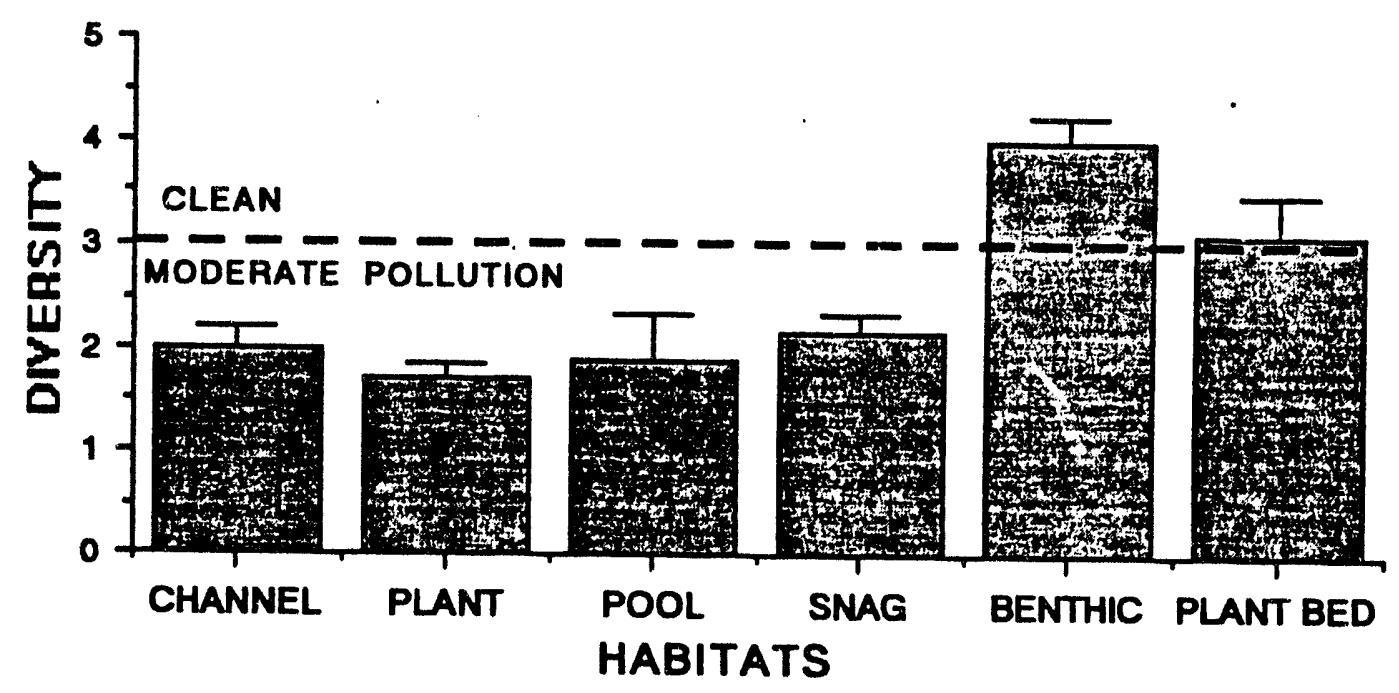

Figure 3.3. Values from Shannon-Weaver's diversity index (tSE) among habitats. Dashed line represents Wilhm's (1970) interpretation of water quality based on diversity. 


\section{Biotic Index}

Using the criteria of Hilsenhoff (1982), the average annual biotic index values for macroinvertebrate assemblages (Figure 3.4) showed water quality to be slightly different from that shown by the diversity index. Collections of organisms from pools, snags, benthic, and whole plant beds indicated good water quality in these habitats. By the criteria of Hilsenhoff (1982), mid-channel and plant stem habitats were shown to have only fair water quality. Values in the main channel were significantly different from all other habitat types and had a mean biotic index value of 3.5 which was near Hilsenhoff's (1982) criteria for poor water quality.

\section{Ratio of EPT to All Taxa}

The application of habitat-specific EPT ratios (Figure 3.5) showed the main channel to have the worst water quality because it had no member in the EPT group. Snag habitats had the greatest percentage of fauna as members of the EPT group but was statistically different only from plant stems and the main channel habitat. The important component in the EPT group in the snags came from the abundance of filtering Trichoptera (Appendix C).

\section{Functional Feeding Groups}

Organisms from the sandy-bottomed main channel (Figure 3.6) were composed primarily of predators $(43 \%)$, scrapers $(33 \%)$, and collector-gatherers $(22 \%)$.

The plant-stem community (Figure 3.7) was dominated by filterers (63\%). Shredders, which made up $12 \%$ of the community, were primarily herbivorous Lepidoptera which use living aquatic plants as a food resource. Collectorgatherers made up $13 \%$ of the invertebrate association. 


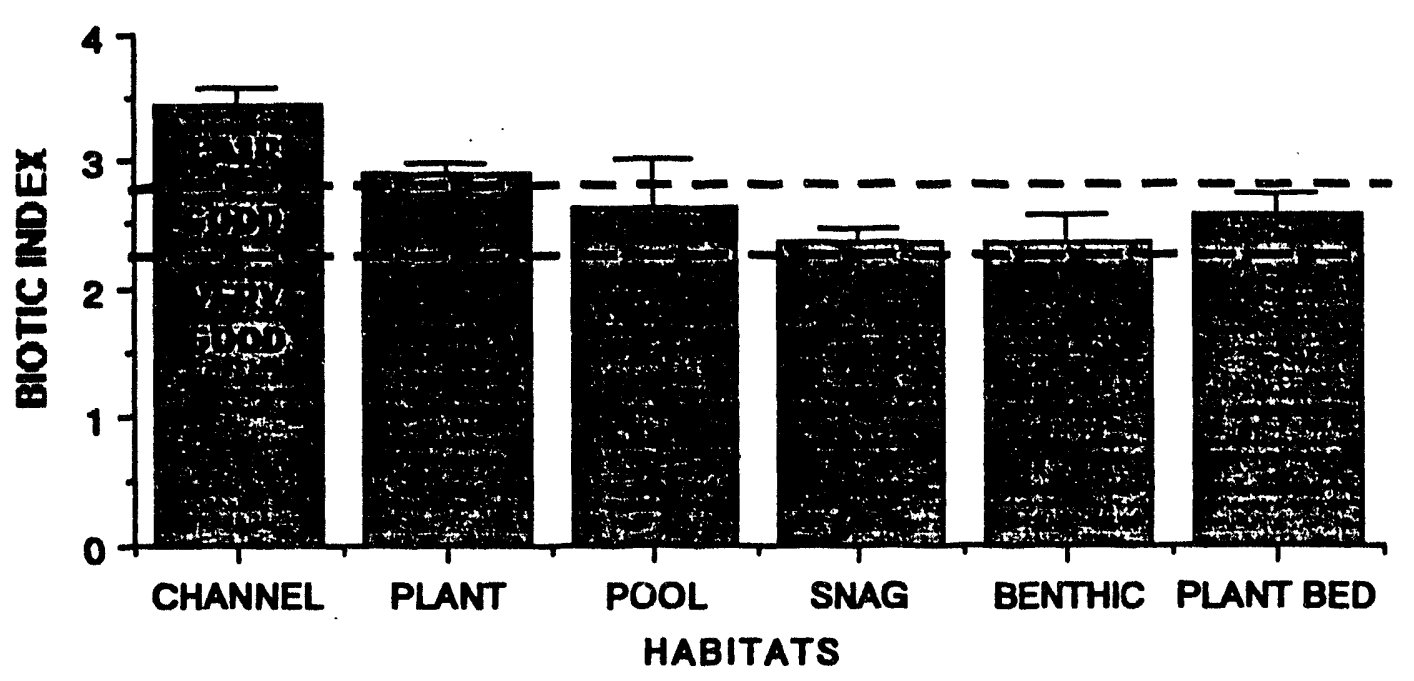

Figure 3.4. Average annual biotic index values $( \pm S E)$ among habitats. Dashed lines designate water quality levels of Hilsenhoff (1982).

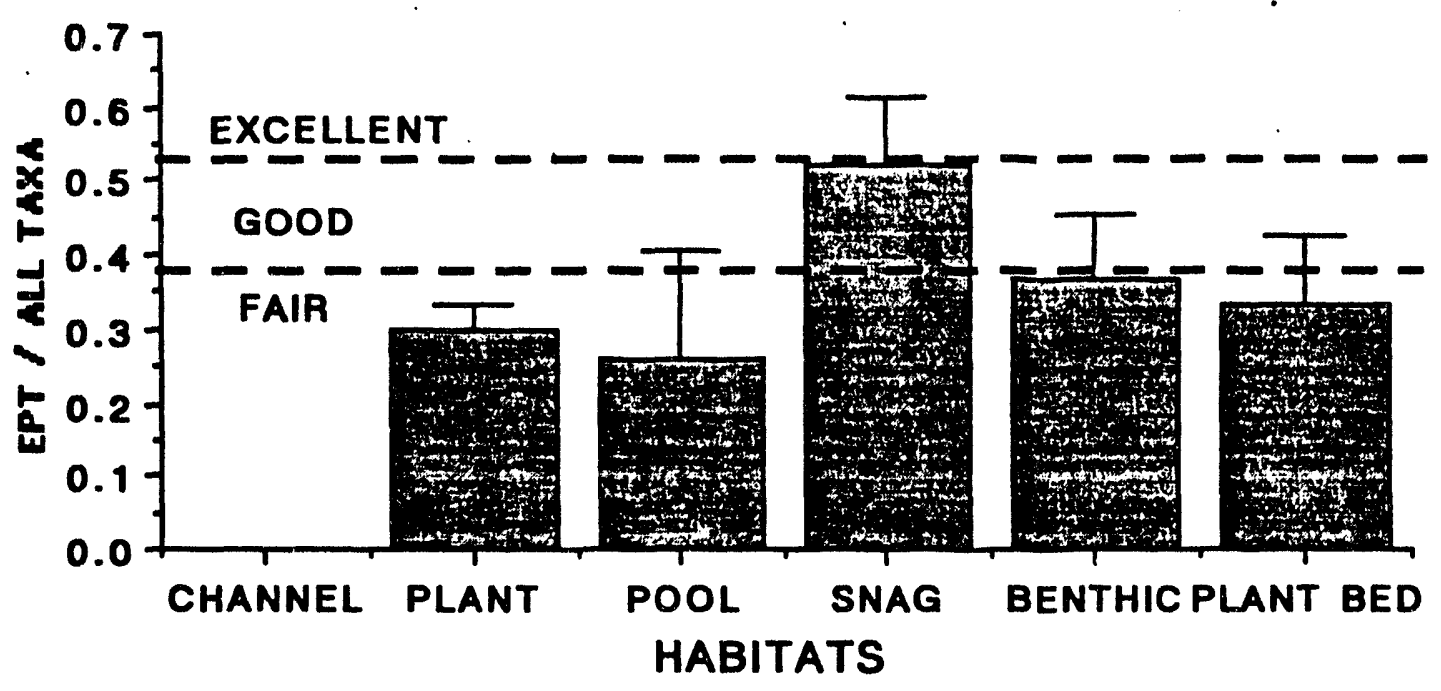

Figure 3.5. Average annual EPT ratio to all other taxa ( $t S E)$ among habitats. Water quality criteria are from EPT ratios developed from data provided in (Lenat et al. 1988). 


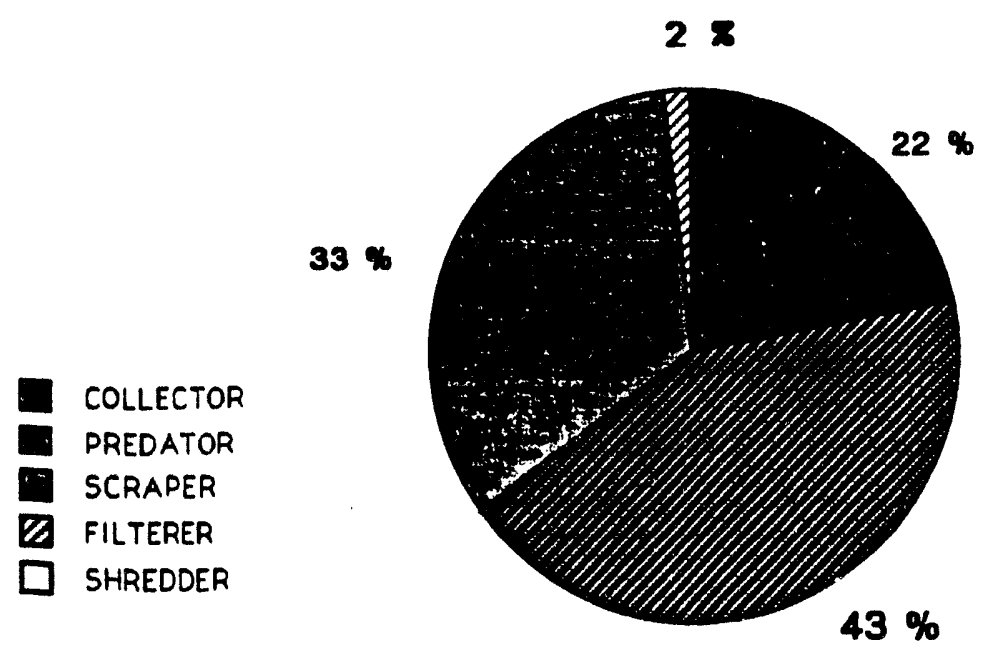

Figure 3.6. Functional feeding group percentages of invertebrates in the main channel habitat.

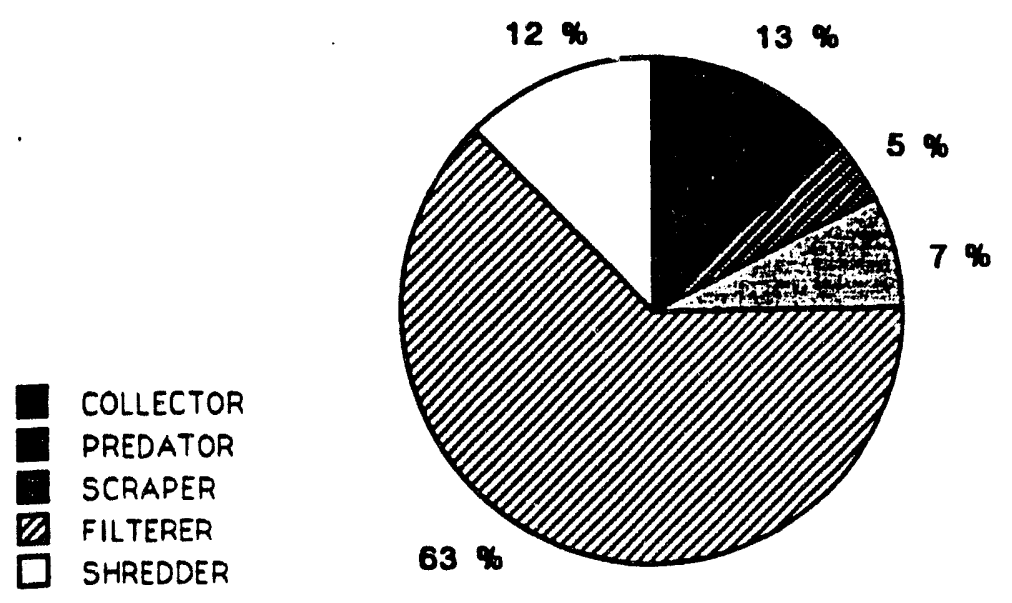

Figure 3.7. Functional feeding group percentages of invertebrates in the plant habitat. 
The community in the highly organic pool (Figure 3.8) was composed primarily of collector-gatherers $(51 \%)$, oredators $(37 \%)$, and scrapers $(10 \%)$.

Snag habitats (Figure 3.9) were structurally the most stable substrate in the stream. The functional feeding group organization was dominated by filterers $(72 \%)$. Scrapers, collector-gatherers and predators made up $11 \%, 8 \%$, and $7 \%$, respectively.

Benthic habitat (Figure 3.10) located below the aquatic plant stems had the most even distribution of organisms among the feeding groups. Collectorgatherers made up $42 \%$ of the fauna, predators $27 \%$, scrapers $16 \%$ and filterers were $10 \%$ respectively. Shredder type feeders made up $5 \%$ of the feeding groups and were from three taxa, Leuctra Sp. (Plecoptera: Leuctridae), Neureclipsis crepuscularis (Walker) (Trichoptera: Polycentropodidae), and Agarodes sp. (Trichoptera: Sericostomatidae).

\section{Percentage Similarity}

The percentage similarity of taxa among habitat types (Table 3.1) provided an indication of habitat overlap by macroinvertebrates. Plant stems and snag type habitats had the most taxa in common. Plant and benthic neighbors shared $41 \%$ of their taxa. Plant stem and pools shared $39 \%$ of their taxa. Lowest percentage similarity of taxa was between the snag and pool and the snag and main channel habitat types.

\section{Coefficient of Variability}

Within the main channel habitat, coefficient of variability (CV) (Table 3.2) was lowest in the EPT ratio because no members of the EPT group were present. The biotic index showed the lowest deviation to mean ratio of all other indices and among all habitat types. Within plant stems, density had the highest 


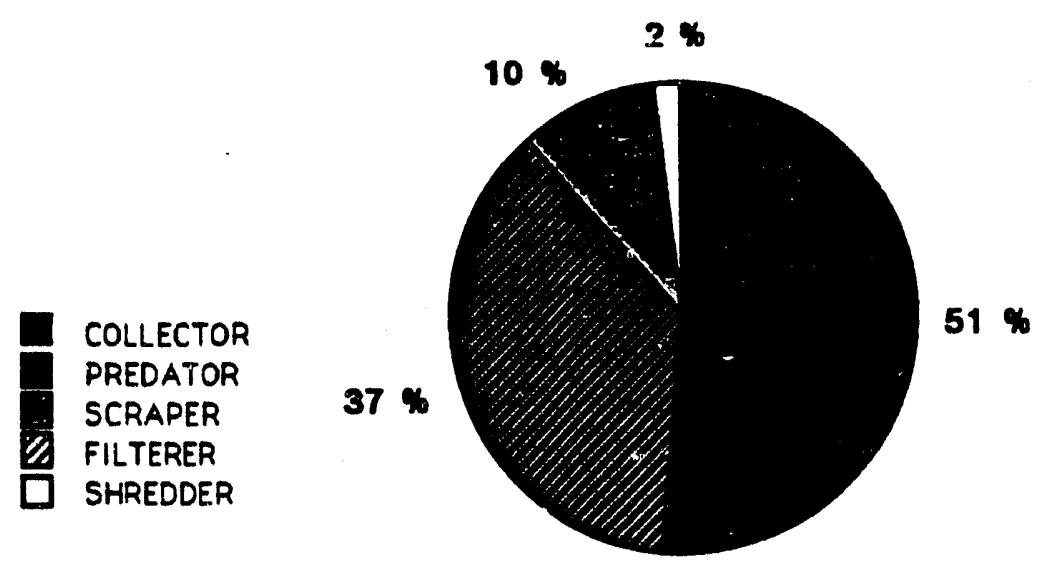

Figure 3.8. Functional feeding group percentages of invertebrates in the pool habitat.

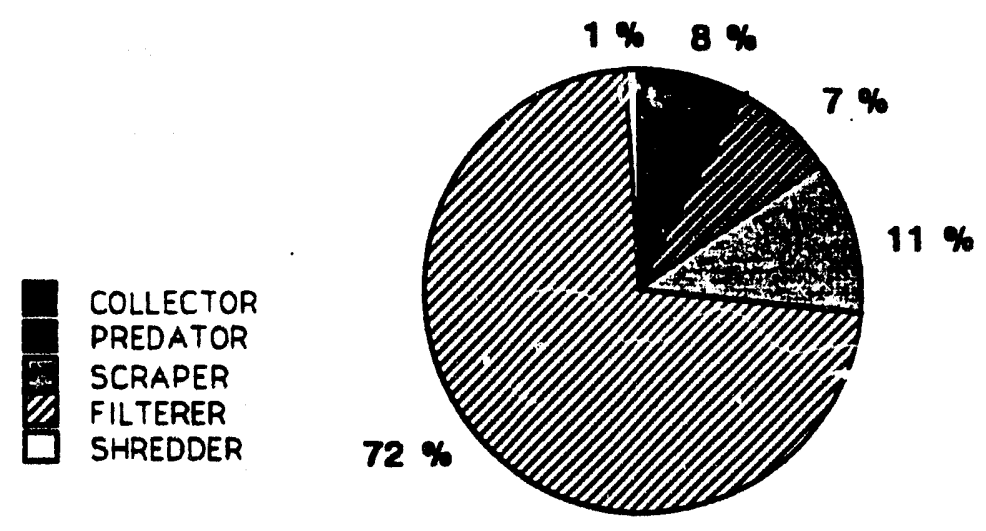

Figure 3.9. Functional feeding group percentages of invertebrates in the snag habitat. 


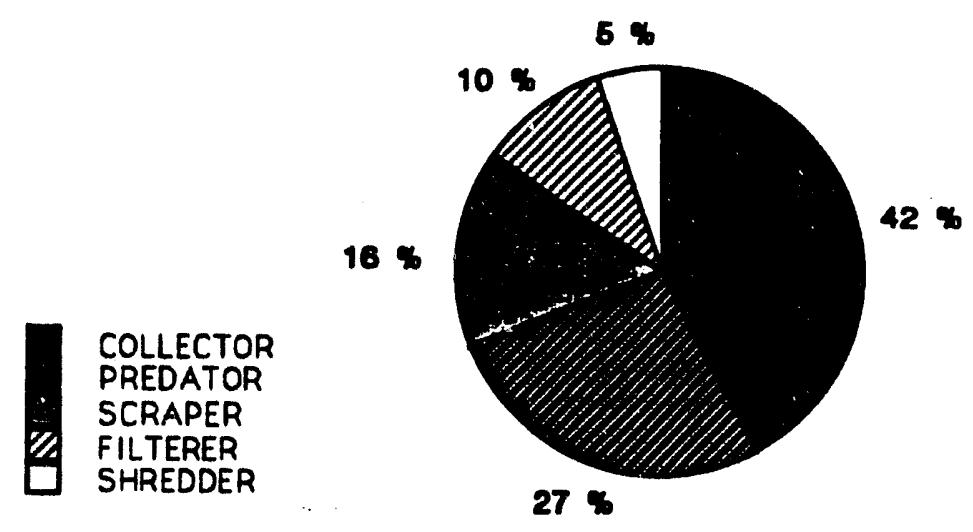

Figure 3.10. Functional feeding group percentages of invertebrates in the benthic habitat.

Table 3.1. Percentage similarity in taxa between habitat types and years sampled.

Habitat

$\%$ Similarity

\begin{tabular}{ll}
\hline Plant - Snag & 61 \\
Plant - Benthic & 41 \\
Plant - Pool & 39 \\
Plant - Main Channel & 33 \\
Snag - Benthic & 34 \\
Snag - Pool & 22 \\
Snag - Main Channel & 22 \\
Benthic - Pool & 34 \\
Benthic - Main Channel & 34 \\
Main Channel - Pool & 26
\end{tabular}

Years

$1984-1985$ 
CV, while in pools the highest CV was in the EPT ratio category. In snags, CV was greatest for invertebrate density values. In benthic samples, the CV was greatest in the EPT ratio, and in the total plant bed the CV was again greatest in the EPT ratio.

Table 3.2. Coefficient of variation (CV) for biological indicators of water quality among habitats.

\begin{tabular}{lccccc}
\hline Habitat & Density & Taxa Richness & Diversity & Biotic index & EPT Ratio \\
\hline Channel & 22.268 & 24.187 & 23.096 & 8.558 & 0 \\
Plant & 75.075 & 34.791 & 39.558 & 12.845 & 65.630 \\
Pool & 50.185 & 43.205 & 49.721 & 31.017 & 111.380 \\
Snag & 110.255 & 44.480 & 35.574 & 20.320 & 57.220 \\
Benthic & 49.990 & 32.390 & 13.206 & 23.566 & 52.440 \\
Plant Bed & 47.097 & 57.715 & 40.957 & 20.303 & 88.540 \\
& & & & & \\
\hline
\end{tabular}

\section{Temporal Variability}

The macroinvertebrate community structure in UTRC showed little change between 1984 and 1985. Average organism density (Figure 3.11) declined slightly between 1984 and 1985 but the difference was not significant. There was a slight, but not significant increase in average taxa richness (Figure 3.12) from 85 in 1984 to 94 in 1985. Shannon's Diversity index (Figure 3.13) showed a slight increase in water quality from 1984 to 1985 . Water quality according to Wilhm (1970), was considered "clean" for both years. The biotic index (Figure 3.14) showed a decline in water quality through time but the differences between 1984 and 1984 were not significant. EPT Ratio (Figure 3.15) increased slightly from 1984 to 1985 but increase was not significant 
statistically. The percentages of organisms in different functional feeding groups (Figure 3.16) changed statistically between years only in the shredder feeding group. This group had the least representatives in UTRC, and was composed primarily of Lepidoptera larvae. Samples collected in the years 1984 and 1985 showed a 78 percentage similarity of taxa. Coefficient of variation (Table 3.3) of pooled macroinvertebrate data collected in UTRC showed that the lowest deviation to mean ratio was in the biotic index during 1984 and in taxa richness during 1985. Lowest CV for both years was in taxa richness and biotic index values. Greatest variability among indices during 1984 and 1985 was found in the EPT ratio.

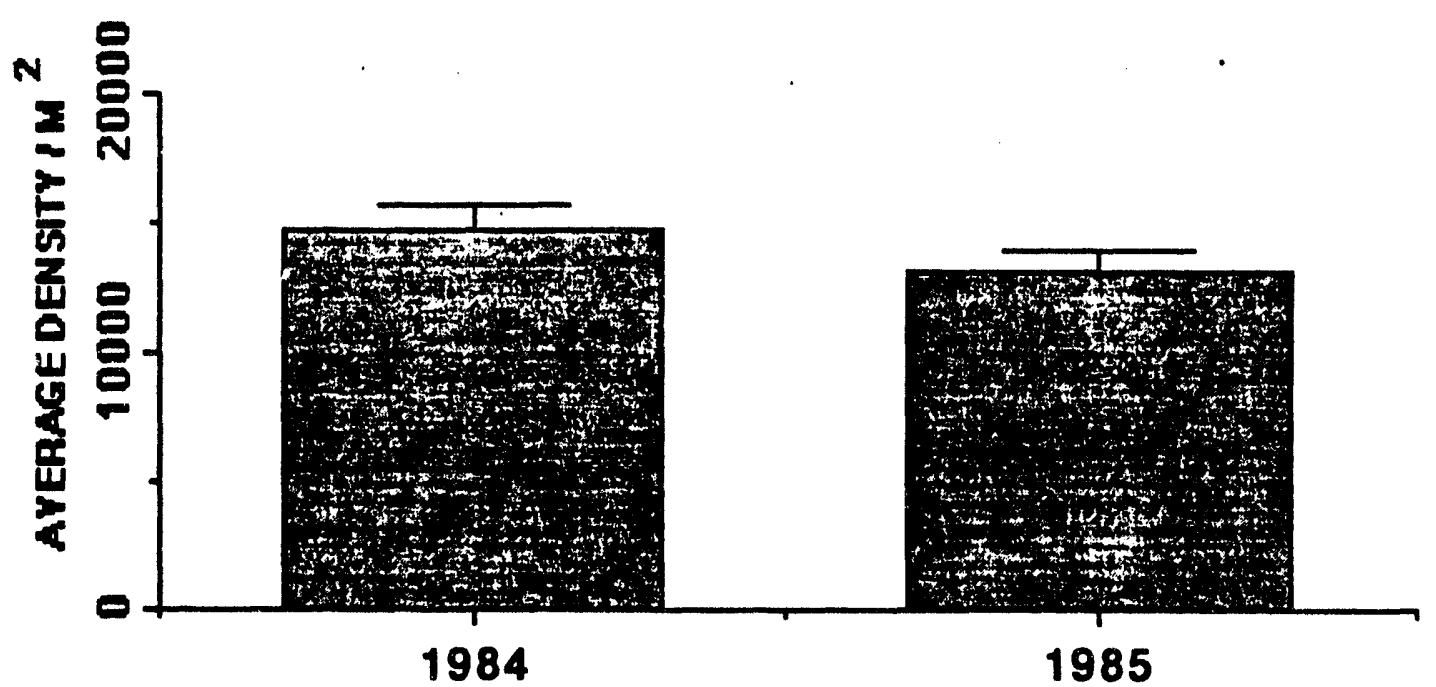

Figure 3.11. Average annual density of organisms (tSE) among years. 


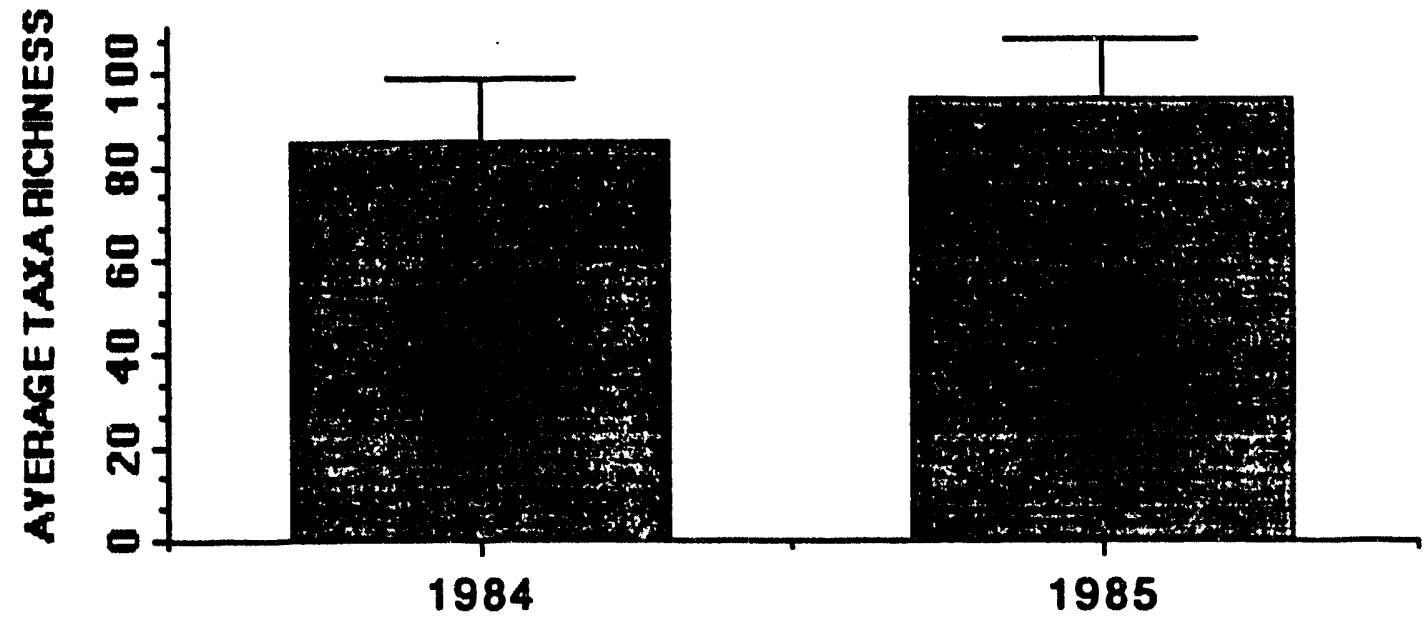

Figure 3.12. Average annual taxa richness $(t S E)$ among years.

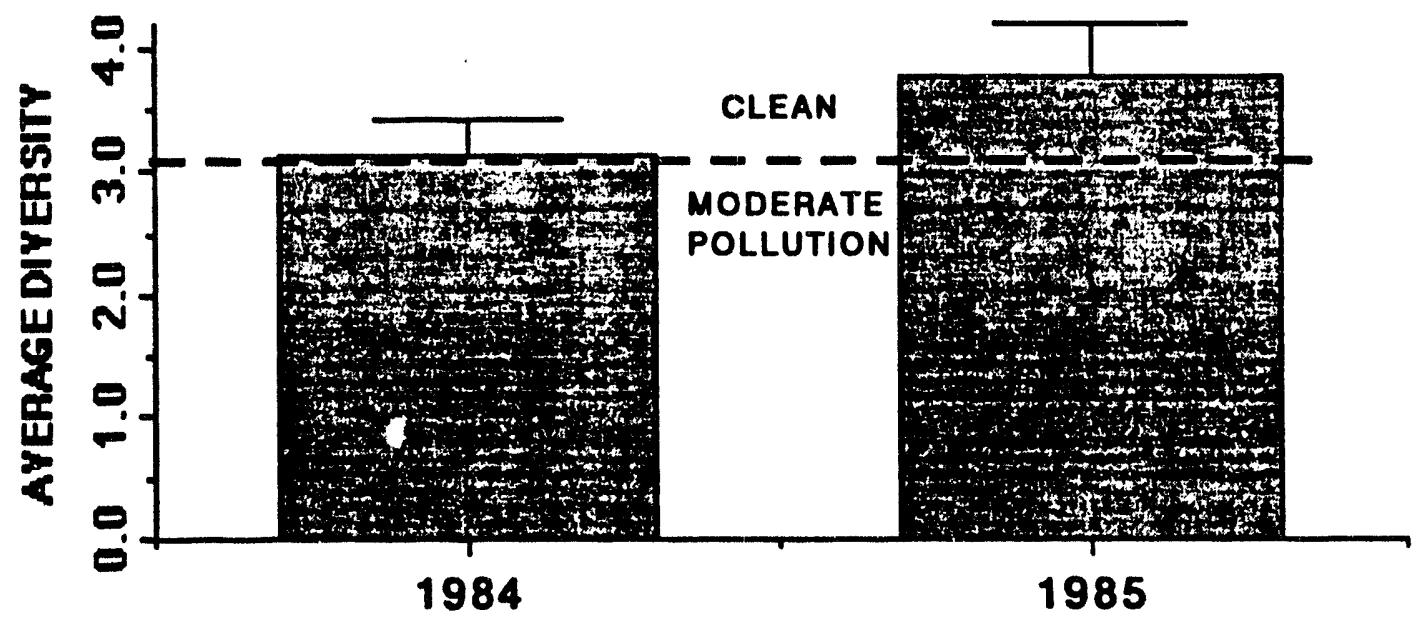

Figure 3.13. Values from Shannon-Weaver's diversity index $(t S E)$ among years. Dashed line represents Wilhm's (1970) interpretation of water quality based on diversity. 


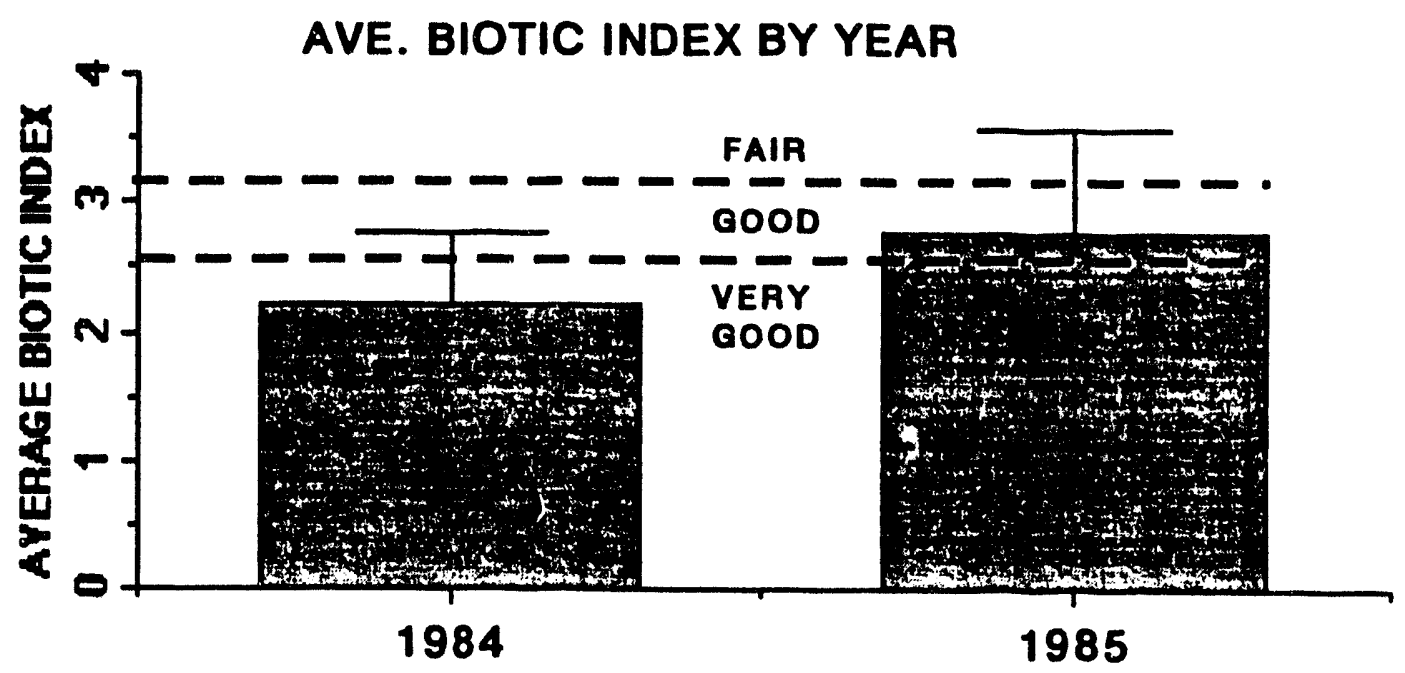

Figure 3.14. Average annual biotic index values ( \pm SE) among years. Dashed lines designate water quality levels of Hilsenhoff (1982).

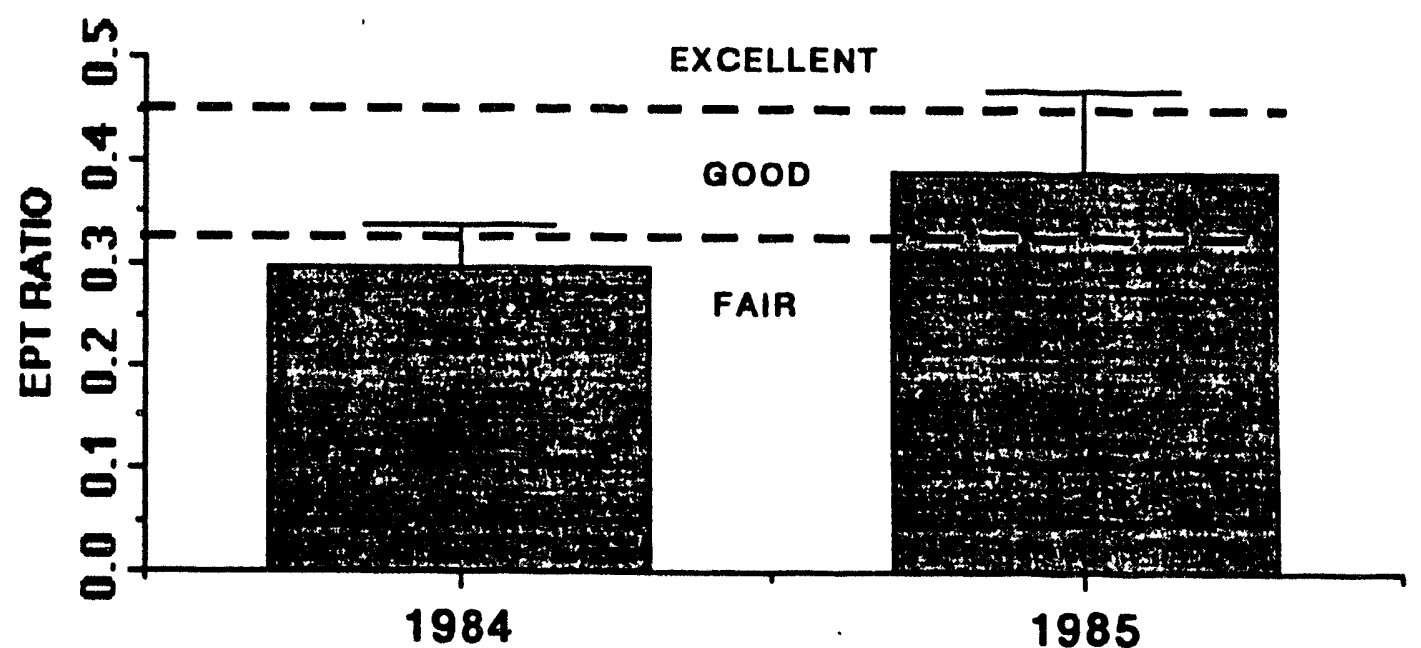

Figure 3.15. Average annual EPT ratio to all other taxa $(t S E)$ among years. Water quality criteria are from EPT ratios developed from data provided by Lenat et al. (1988). 


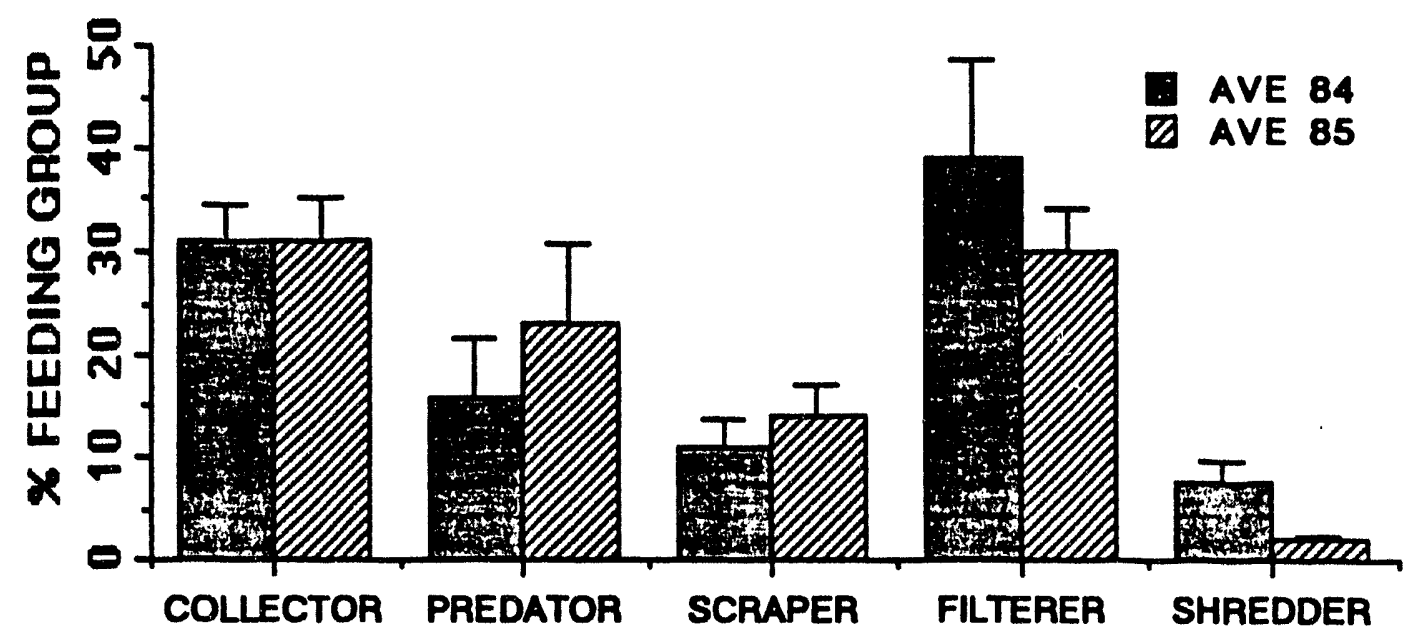

Figure 3.16. Functional feeding group percentages of invertebrates for both years in all habitats.

Table 3.3. Coefficient of variation (CV) for the biological indicators of water quality for the years 1984 and 1985.

\begin{tabular}{lcc}
\hline Biological & CV & CV \\
Indicator & 1984 & 1985 \\
\hline Density & & \\
Taxa Richness & 52 & 48 \\
Diversity & 34 & 24 \\
Biotic Index & 30 & 25 \\
EPT Ratio & 24 & 29 \\
& 56 & 66 \\
\hline
\end{tabular}




\section{Discussion}

The community structure appeared to be quite variable in space (e.g. among habitat types) but showed little variability through time. The manipulation of the community data into a set of commonly used biological indices provided insight on the characteristics of each habitat type and showed some of the problems with the application of biological indices to certain types of data.

\section{Spatial Variability}

\section{Main Channel}

The main channel habitat was composed of unstable sandy material and had a community structure specialized to take advantage of that characteristic (Williams 1984). Nearly the entire community was composed of chironomid larva (Appendix C) which were small enough (less than $1 \mathrm{~cm}$ long) to move around within the sandy substrate (Soluk 1985). Despite the unstable nature of this habitat type, organism density was extremely high (averaging 13750 per $\mathrm{m}^{2}$ ) relative to other habitats in UTRC, but was lower than that shown by Benke et al. (1984) for sandy bottomed substrates in the Satilla River, Georgia. Application of popularly used biological indicators of water quality to the taxonomic composition of the main channel community showed this habitat to have the poorest water quality of all habitat types. The diversity index values (Figure 3.3) were low primarily because distribution of organisms in the sandybottomed substrate is likely to be very patchy (Pringle et al. 1988). And use of small-sized samples may have caused a misrepresentation of organism abundance and taxonomic distribution (Resh 1979). Biotic index values (Figure 3.4) were low primarily because the community was dominated by the chironomid predator Conchapelopia sp. which has a high pollution tolerance 
value of 4. EPT ratios (Figure 3.5) in the main channel were zero because no members of those taxonomic groups were present. Functional feeding group percentages (Figure 3.6) were similar to other regional studies of sandy substrates (Benke et al. 1984, Smock et al. 1985) except for the relative abundance of scrapers. The fauna of the main channel was most similar to the benthic fauna (Table 3.1) which is it's closest neighbor.

\section{Plant Habitat}

The plant stem habitat had high organism abundance (Figure 3.1) and was taxonomically the richest (Figure 3.2) of habitats measured on a single plane. Functional feeding groups were dominated by filter-feeders (Figure 3.7). The filtering mechanisms (Cummins and Klug 1979) of taxa within the filterfeeding group was different on aquatic plants than on snags (Table 3.4). Organisms which use part of their body to filter food particles from the water column were considered anatomical filterers and made up $45 \%$ of filterers on the plants compared to $18 \%$ in the snag habitats. Also, taxa which made small filtering nets were proportionately more abundant on plant stems than on snags. Conversely, filterers which spin large filtering nets occurred on snags 3.5 times more than on plant stems. Apart from predation effects (Peckarsky 1984) and behavioral displacement (Power et al. 1988), neither of which were measured, the distribution of filter-feeding mechanisms among these two different habitats appeared related to substrate stability. Because snag material is composed of relatively nonflexible wood, its movement in the water column should be less than flexible strands of ribbon-like plant material. Structural differences among habitats probably caused the differences in percent of filter-feeding organisms with different filtering mechanisms. A direct cause-and-effect relationship was not apparent but needs to be investigated. 
Table 3.4. Relative abundance of filter-feeding groups within the filter-feeding group category in aquatic plant habitats versus snag habitats. Small nets were considered to be less than $5 \mathrm{~mm}$ wide.

\begin{tabular}{lccl}
$\begin{array}{l}\text { Filtering } \\
\text { Genus }\end{array}$ & $\begin{array}{c}\text { \% Occurrence } \\
\text { Aquatic Plant }\end{array}$ & $\begin{array}{c}\text { \% Occurrence } \\
\text { Snag }\end{array}$ & $\begin{array}{l}\text { Filtering } \\
\text { Mechanism }\end{array}$ \\
\hline $\begin{array}{l}\text { Microtendipes } \\
\text { Rheotanytarsus }\end{array}$ & 3 & 6 & Net Spinner (small) \\
Simulium & 2 & 19 & Net Spinner (small) \\
Brachycentrus & 43 & 2 & Anatomical \\
Ceratopsyche & 4 & 16 & Anatomical \\
Cheumatopsyche & 2 & 13 & Net Spinner (large) \\
Chimarra & 0 & 18 & Net Spinner (large) \\
Hydropsyche & 7 & 1 & Net Spinner (large) \\
Macrostemum & 0 & 15 & Net Spinner (large) \\
Neureclipsis & 2 & 1 & Net Spinner (large) \\
Nyctiophylax & 0 & 6 & Net Spinner (large) \\
Polycentropus & 1 & 1 & Net Spinner (large) \\
Potamyia & 0 & 0 & Net Spinner (large) \\
\end{tabular}

Percentages of

Anatomical Filterers $\quad 45$

Small-Net Spinning

Filterers

39

25

Anatomical Filterer + Small-Net Spinning Filterers

Large-Net Spinning

Filterers 
Pools

Pools had the lowest organism density (Figure 3.1) and low taxa richness (Figure 3.2). They were located in areas of lowest current velocity, and were composed of deep organic deposits (section 2). Functional feeding groups (Figure 3.8) were dominated by collector-gatherers which presumably used the organic matter as a food resource. The second most abundant feeding group represented in the pool habitats were predators which may have been partly responsible for low organism abundance.

\section{Snag}

Snags had intermediate taxa richness (Figure 3.2), and low organism abundance (Figure 3.1). This habitat was dominated by filter-feeding organisms (Figure 3.9). Snags and plants had $61 \%$ similarity in taxa primarily because both habitats were the primary stable substrates used by filter-feeders. Research conducted by Benke et al. (1984) and Smock et al. (1985) in southeastern sandy-bottomed streams showed snags to be extremely important to production in these systems.

\section{Benthic Habitat}

Benthic habitats had high organism density (Figure 3.1) and taxa richness Figure 3.2). They also showed the best water quality based on the diversity index (Figure 3.3) and biotic index values (Figure 3.4). EPT ratios (Figure 3.5) were second highest. Functional feeding groups (Figure 3.10) in the benthic habitat were dominated by collector-gatherers which presumably were using the organic detritus accumulated in this habitat. Because of the close proximity to the plant stem material, considerable movement between habitat types could be expected. Percentage similarity values showed that benthic and plant stem habitat types had $41 \%$ of their organisms in common. 


\section{Plant Beds}

Combining the benthic taxa association with that of plants based on a unit area of creek bottom, showed the importance of the plant bed habitat to the system. It had over 3 times the organism density of the mid-channel area (Figure 3.1) and more taxa (Figure 3.2). Diversity (Figure 3.3), biotic index values (Figure 3.4) and EPT ratios (Figure 3.5) all suggested good water quality.

\section{Temporal Variability}

Comparisons of community structure and biological indicator values for 1984 and 1985 showed no change. As was shown in previous studies by Morse et al. (1980, 1983 ), Morse and Kelley (1982), functional feeding group ratios did not change through time. The lack of change in this system may be due, in part, to the highly consistent flow and predictability of discharge (section 2). However, a change in discharge (natural or induced by man) may alter the the community structure and subsequently the biological indicators of water quality (Gurtz 1984, Gurtz and Wallace 1984).

\section{Application of Biological Indices}

One of the objectives of this research was to determine what effects variability in community structure would have on commonly used, communitystructure-based indices of water quality. The research showed considerable differences in community-based, biological indices among the different habitats (high spatial variability) and little difference in biological indices between years (low temporal variability).

Spatial Variability

Stratification of sampling among habitat types was recommended by Resh (1979) to decrease the variability in data caused by the heterogeneous 
distribution of aquatic macroinvertebrates. Certain characteristics of habitats, particularly current velocity, substrate size and food resources, are selected by aquatic organisms. Selection of specific resources provided by discrete habitats results in the patchy distribution of organisms common in rivers and streams (Pringle et al. 1988).

The differences associated with the effect of the application of water quality indices to single habitat types was demonstrated visually, in Figures 3.13.5. The CV values (Table 3.2) demonstrated the high level of variability among indices within habitats. Because biological indicators of water quality were determined from samples of invertebrates collected in only 5 specific habitat types, the biological indicators of water quality from the individual habitat types cannot be considered to represent the water quality of the stream as a whole. Because all habitats sampled share the same column of water, different habitats located within several meters of one another would not have different water quality as suggested by index values based on specific habitats. These data demonstrate that macroinvertebrate assemblages were not similar in different habitats and that sampling of specific habitats can yield very different community level evaluations of water quality. The importance of sampling all habitats when attempting to assess water quality using biological indices was demonstrated.

Because samples were taken only within specified habitats, all organisms using habitats other than those sampled were not included in analysis. Organisms which use other habitats, or the edges of sampled habitats may have been missed or under-represented. The percentage similarity of taxa between habitat types sampled was greater than $50 \%$ in only one comparison. This suggests that there are considerable taxonomic differences among habitat types and that unsampled habitats may contain additional, 
unlisted taxa. It has long been recognized in terrestrial systems (Leopold 1933) that the ecotone (zone of integration between habitat types) contributes substantially to organism abundance and taxonomic richness of an area. Because UTRC samples were collected only within discrete habitat types, all edge effects were avoided, and, in so doing, perhaps a large portion of available organisms were not sampled. In addition, application of the EPT values to unit-of-area data is probably not appropriate, As Lenat (1988) recommended the :se of timed sampling among all habitat types.

Because the sampling design used in this study was habitat specific, biological indicator values provided in this paper should not be considered to represent, in any way, the water quality of UTRC.

\section{Temporal Variability}

Water quality indices determined from biological samples collected in UTRC, in most cases showed no change between 1984 and 1985 (Figure 3.113.16) but there were differences in the variability shown by the different biological indicators (Table 3.3). Those with high CV would not be good indicators of water quality or of community structure because they demonstrated high intersample variability (Resh 1988). As a comparison, analysis of macroinvertebrate data sets that have 4 to 6 years of whole stream (not habitat specific) samples (Resh 1988) showed CV values were lowest in EPT taxa counts (18\%), taxa richness (21\%), and diversity values $(20 \%)$. In UTRC, the trend for CV values was similar to that shown by Resh (1988). The CVs were lowest for taxa richness, diversity and biotic index. Given this type of sampling, biotic index values would be the best to use in UTRC to indicate water quality. Resh (1988) also set a standard of $<50 \%$ annual change in variability as an acceptable level of change before water quality problems are suspected. The 
CVs for community level water quality indices showed little change between 1984 and 1985.

The annual community-based indices of water quality should not be used as indicators oi true water quality of UTRC. These data are based on habitat specific data and as such may consider only a small portion of the fauna. The whole of the system is much greater than the sum of the parts, especially when all parts are not included.

\section{Conclusions}

There were considerable differences between habitats for the values of community-structure-based indicators of water quality. The differences in community structure reflect the differences in the habitat types. Functional feeding group ratios were different between the habitats and indirectly demonstrated the use or availability of different food resources within specific habitats.

Indices of water quality based on community structure showed minimal change between 1984 and 1985. Functional feeding group percentages showed minimal change between years and suggests that ford resources for aquatic macroinvertebrates changed little.

Because water quality indices were based on a few, specific habitat types, the values presented in this paper should not be considered as indicative of the water quality in UTRC as a whole stream. Rather, the habitat specific indices provided in this paper should serve to demonstrate the possibility of misinterpretations of data from samples which did not include all habitat types and the ecotones between them. 


\section{CONCLUSIONS}

The basin formation of UTRC was primarily sand and may be considered unstable for many macroinvertebrates. However, burrowing chironomidae were abundant in the sandy bottom main channel areas and had mean densities of $13,750 / \mathrm{m}^{2}$. Because the discharge was quite constant and highly predictable, aquatic macrophyte beds had developed. Snags and aquatic macrophytes provided the only stable substrates in the stream. The macroinvertebrate community associated with snags was dominated by filter-feeding organisms.

Aquatic macrophytes functioned as a food resource for herbivorous lepidoptera larva and, following senescence, entered the detrital pool. Plants also altered current velocity which resulted in high accumulation of BOM within the plant beds. Macrophytes also provide a substrate for the growth of epiphytic algae and associated bacteria and detritus. The community of aquatic invertebrates associated with plants was alșo high in taxa richness and was dominated by filter feeding organisms. Collector-gatherers were relatively more abundant on plants than on snags and were probably responding to the epiphytic and aufwuchs food resource. Macrophytes, in response to solar input, had primary control of diel patterns in dissolved oxygen and pH in the creek.

Daily peaks for dissolved oxygen and $\mathrm{pH}$ were in the early afternoon during maximum photosynthetic activity.

Snags altered current velocity and channel morphometry. Through this process snags controlled the distribution and abundance of aquatic plant beds which in turn controlled the distribution of aquatic invertebrates in the aquatic plant habitat. The position, depth and width of the main channel habitat type appeared controlled by the interactions of snags and aquatic plant beds and 
their subsequent influence on hydraulics. Main channel alterations by current velocity would probably affect the distribution of aquatic invertebrates in that habitat type as well through scour or possibly burial.

Pools were areas where the effects of gravity on the lateral movement of water have been nearly neutralized. Pool macroinvertebrate densities were low as was taxa richness. The fauna was made up primarily of collector gatherer feeding group members. Pools were short-lived in UTRC and were either captured by the main channel or overgrown by aquatic plants.

The environmental variable that exerts primary control over habitats in UTRC is discharge. Any alteration of the existing discharge regime (natural or anthropogenic) will change this system. During the period research was conducted on UTRC, only one minor high discharge event was observed. Macroinvertebrate community structure was not changed substantially between the years 1984 and 1985. Functional feeding group percentages showed only minimal change. This system exhibits a stability (primarily because of discharge) that may be unique among blackwater Sandhills streams that has allowed UTRC to develop a community rich in species (including $650+$ insect species) which are distributed widely among many different habitats.

Each habitat type provided a unique combination of chemical, physical and organic resources from which potential and existing inhabitants could select. Past experience has shown that the distribution of organisms within stream boundaries is dependent upon how specific resources are distributed (Minshall 1984). If this is the case, then Southwood's (1977) proposition that habitats are the templates for ecological strategies is appropriate for UTRC. 
$\mid$

APPENDICES 
Appendix A

Iypical Printout of the Data Collected at the Remote Site after It Has Been Loaded onto Clemson University Mainframe Computer as a Statistical Analysis System (SAS) Data Set

Data in the first 15 columns came directly off the audio cassette recorder and were downloaded to the mainframe with the Campbell C2O cassette computer interface. Data in columns 16-19 are mathematical manipulations of these data. Variable labels are given across the top and are defined as follows: OBS $=$ observation number, DAY $=$ Julian date, HOUR $=$ Hour on a 24-hr clock at which data were collected, DOMEAN = Mean dissolved oxygen level for the hour over which data were continuously recorded. DOMAX = Maximum dissolved oxygen level for the hour over which data were continuously recorded. DOMIN = Minimum dissolved oxygen level for the hour over which data were continuously recorded. PHMEAN = Mean millivolt output for the $\mathrm{pH}$ meter. PHMIN = Minimum millivolt output from the $\mathrm{pH}$ meter. PHMAX = Maximum millivolt output from the $\mathrm{pH}$ meter. TEMTMEAN $=$ Mean temperature at the top of the water column. TEMTMAX = Maximum temperature at the top of the water column. TEMTMIN = Minimum temperature at the top of the water column. TEMBMEAN = Mean temperature at the bottom of the water column. TEMBMAX = Maximum temperature at the bottom of the water column. TEMBMIN = Minimum temperature at the bottom of the water column. ALLSAT $=$ The $\mathrm{mg} / \mathrm{l}$ of dissolved oxygen that would be present if the water were at $100 \%$ saturation given the mean temperature at the top of the water column (TEMTMEAN). The $100 \%$ saturation values (ALLSAT) were determined from a regression formula I developed based on the solubility of oxygen in pure water 
at equilibrium with pure air at one atmosphere presented by Cole (1983). The regression equation was

$$
\mathrm{mg} / \text { liter DO } @ 100 \%=-0.187 X=12.844\left(r^{2}: 0.999\right)
$$

where $X=$ temperature. Column $18(\mathrm{PH})$ provides computer generated pH values and is the result of mathematical manipulation of millivolt data from column 7 (PHMVMEAN). Millivolts were converted to $\mathrm{pH}$ units for the Beckman meter and probe by the linear equation where

$$
\mathrm{pH}=-17.299 \mathrm{X}+6.806\left(r^{2}: 0.999\right)
$$

and $X=$ millivolts. These $\mathrm{pH}$ values were further converted in column 19 (NEGION) to hydrogen ion concentrations expressed as moles / I. Hydrogen ion concentrations are the antilogs of negative $\mathrm{pH}$ values. The conversions to hydrogen ion concentrations were made so that certain statistical analysis could be applied to the original data. The statistical analysis requiring hydrogen ion concentrations was not required for the work presented here and is presented only to show how pH data can be further manipulated and tested. Column 20 (GROUP) was computer-generated so that values for different times of the day could be grouped together and analyzed. Group 1 was for data collected from midnight to 6:00 am, group 2 from 6:00 am to noon, group 3 froin noon to 6:00 pm, and group 4 from 6:00 pm to midnight. 
$0 \ltimes 0 \supset a$

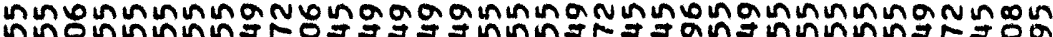

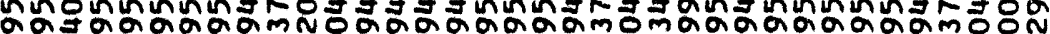
NNENNNN--N-D-NNN-NבNN-NNNNN-NOO N

zwo-oz

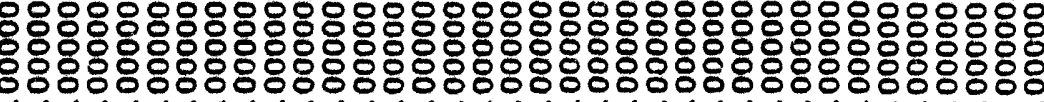
.

a. I

OUzトn<m

$\alpha\lrcorner\lrcorner u<r$

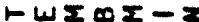

$-w \leq m \leq \ll x$

$\vdash \omega \Sigma \infty \sum \omega<2$

$-w \Sigma+\Sigma-z$

$R \boldsymbol{L} \Sigma \Sigma<x$

$-w \Sigma+\Sigma w<z$

$\sim I \Sigma>\Sigma-2$

$a I \Sigma>\Sigma<x$

$a I \Sigma>\Sigma w<2$

$00 \Sigma-z$

$00 \sum<x$

$00 \Sigma w<z$

IOD

$0<2$

$\infty \infty \omega$

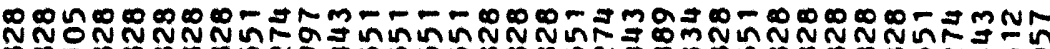

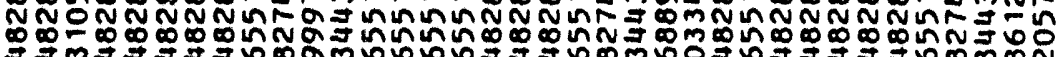

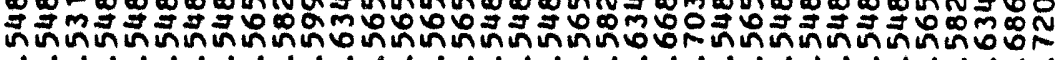

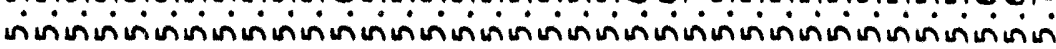
NF

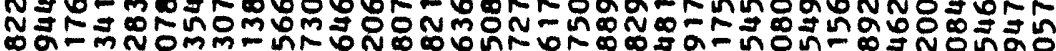
-

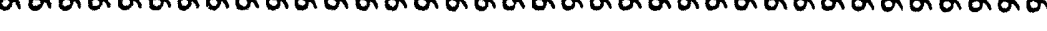

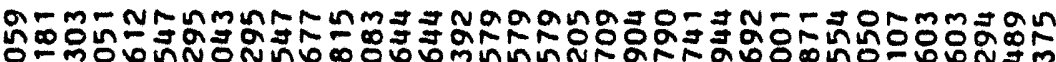

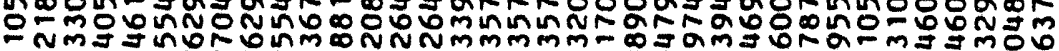

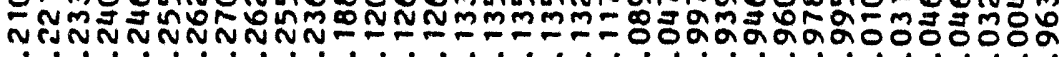

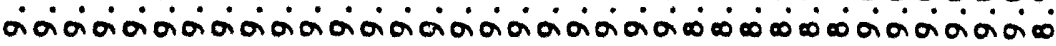
F

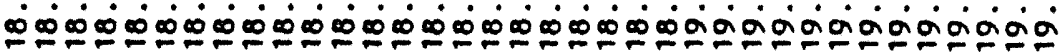

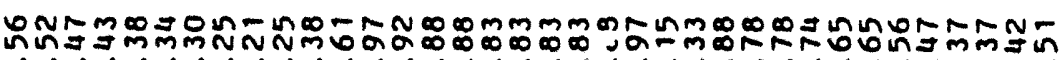

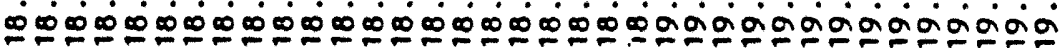

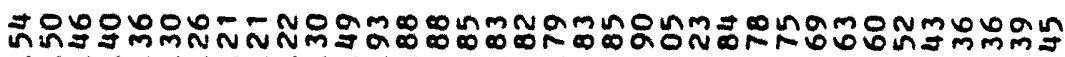

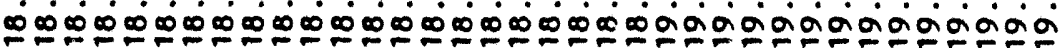

mmN

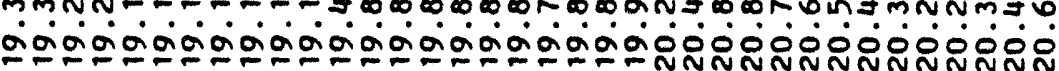

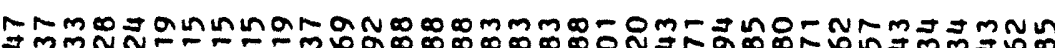

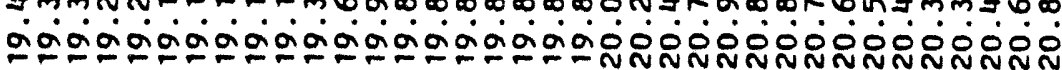

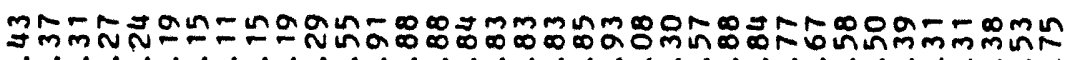

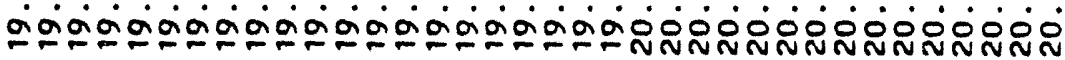

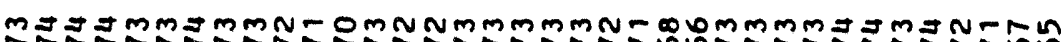

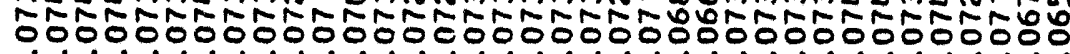
- 0000000000000000000000000000000 mmJMmmmmN-ODNNNNmmm-ONNAmNmmmmmN-NJM

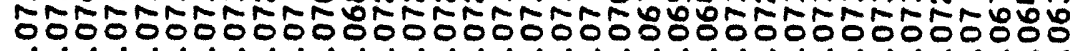

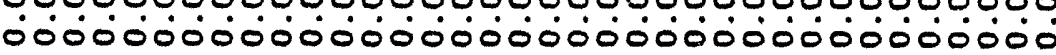

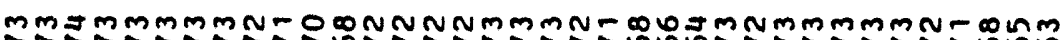

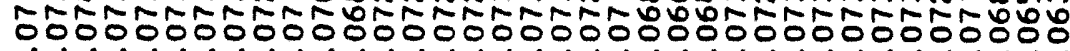

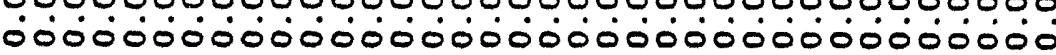

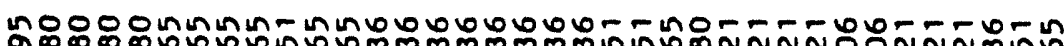

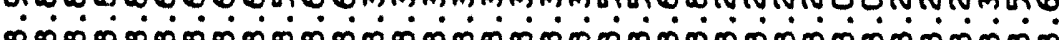

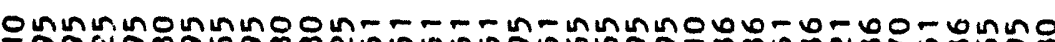
ดดัง ด.

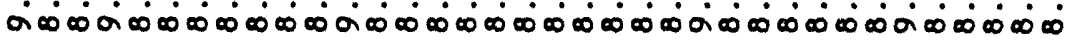

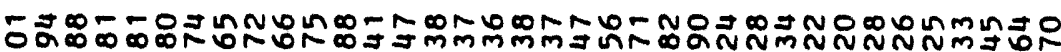

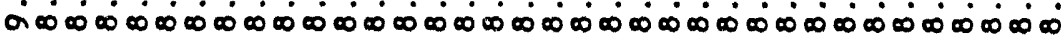

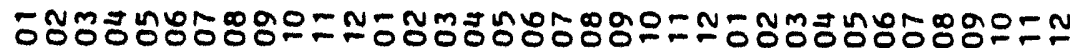
- - - - - - - - KNNNNNNNNNNNmmmmmmmmmmmm

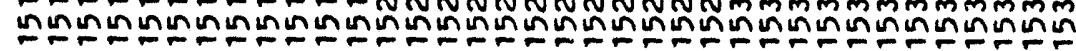
- NM I U 


\section{Appendix B}

\section{Site Descriptions of UTRC Including Boundaries and Total Dimensions}

Site 1 was the downstream-most site. The upstream boundary was flagged, as were all site boundaries, and represented in the stream bed by the snag of a large decaying tree stump. The downstream boundary was located 10 $m$ downstream of the tree stump. Site 1 was the width of the channel (10 m during non-storm periods).

Site 2 butted against site 1 at the downstream boundary and against site 3 at the upstream boundary. The physical upstream boundary was a major bend in the channel. Site 2 was $10 \mathrm{~m}$ long and the width of the channel (10-12 $\mathrm{m}$ during non-storm events).

Site 3 butted site 2 downstream and site 4 upstream. The physical upstream boundary was the end of a large submerged tree (snag) and the overhanging branches of a Maple tree. Site 3 was $10 \mathrm{~m}$ long and $12-14 \mathrm{~m}$ wide during non-storm events.

Site 4 butted against site 3 at the downstream boundary and extended upstream $20 \mathrm{~m}$. The physical upstream boundary was a large, stable block of land which appeared to cause the channel to divert and resulted in the formation of pools downstream from this obstruction. During extreme high flows, water flowed on both sides of this uplifted block.

Site 5 was located $10 \mathrm{~m}$ downstream from Treadway bridge. It bordered site 6 at the upstream boundary and extended downstream for $10 \mathrm{~m}$. Lateral boundaries were from bank to bank (approximately $25 \mathrm{~m}$ ).

Site 6 consisted of a 10-m-long, bank-to-bank transect $(20 \mathrm{~m})$ just downstream of Treadway bridge. The upstream boundary was at the bridge and the downstream boundary was $10 \mathrm{~m}$ from the bridge. 
Site 7 was located on the downstream bend in UTRC. It was $10 \mathrm{~m}$ long and averaged $16 \mathrm{~m}$ wide during non-storm flow. The upstream physical boundary was a major point on the inside edge of a bend.

Site 8 was the most upstream of all sites. The downstream border butted site 7. The site measured $10 \mathrm{~m}$ from the downstream side to the upstream boundary. 


\section{Appendix $C$}

Listing of Taxa Collected in Upper Three Buns Creek. According to Habitat in Which They Were Collected Including Their Biotic Index Value (ai) and Functional Feeding Group Placement (FFG).

MAIN CHANNEL HABITAT TAXA

Diptera

Chironomidae

Cladotanytarsus sp.

Conchapelopia sp.

Cricotopus/Orthocladius sp.

Cryptochironomus sp.

Macropelopia sp.

Microtendipes sp.

- Parachaetocladius sp.

Paracladopelma sp.

Parakiefferiella sp.

Paratendipes sp.

Polypedilum sp.

Potthastia sp.

Robackia sp.

Thienemanniella sp.

Tribelos sp.

Oligochaeta

Tubificidae ai

3

4

3

3

0

2

0

2

2

3

3

1

2

3

3

4

3

4
FFG

collector-gatherer

predator

scraper

predator

predator

filterer

collector-gatherer predator collector-gatherer collector-gatherer collector-gatherer scraper predator collector-gatherer herbivore

scavenger

- A new record for UTRC 
PLANT HABITAT TAXA

Diptera

Chironomidae

Ablabesmyia sp.
Brillia sp.
Chironomus sp.
Conchapelopia sp.
Cricotopus/Orthocladius sp.
Cryptochironomus sp.
Macropelopia sp.
Microspectra sp.
Microtendipes sp.
Nilothauma sp.
Parachaetocladius sp.
Parakiefferiella sp.
Paratendipes sp.
Polypedilum sp.
Potthastia sp.
Rheotanytarsus sp.
Robackia sp.
Stictochironomus sp.
Synorthocladius sp.
Thienemanniella sp.
Tvetinia sp.

Empididae

Hemerodromia sp.

Simuliidae

Simulium sp.

Tabanidae

Tabanus sp.

Tipulidae

Antocha sp.

Ceratopogonidae

Bezzia/Palpomyia complex

Oligochaeta

Tubificidae
3

2

3

3

0

filterer

3

predator

2

2 scraper

3

3 predator

4 scavenger

predator

collector-gatherer collector-gatherer predator

scraper

predator predator collector-gatherer filterer collector-gatherer collector-gatherer collector-gatherer collector-gatherer collector-gatherer scraper

filterer predator

collector-gatherer scraper collector-gatherer collector-gatherer

predator 
Odonata

Calopteryx sp.

3.5 predator

Ephemeroptera

- Acentrella ampla Traver

Baetis sp.

Baetisca rogersi Brener

Baetisca carolina Traver

Ephemerella sp.

Pseudocloeon sp.

Leptophlebia sp.

8 Hexagenia limbata (Serville)

2 scraper

3 scraper

2 collector-gatherer

collector-gatherer

3 collector-gatherer

3 scraper

2 collector-gatherer

1 collector-gatherer

Plecoptera

Leuctra sp.

Perlesta placida (Hagen)

Beloneuria sp.

2 shredder

3 predator

3 predator

Trichoptera

Brachycentrus chelatus Ross

Ceratopsyche sp.

Cheumatopsyche sp.

Molanna blenda Silbley

Micrasema rusticum (Hagen)

Neureclipsis crepuscularis Walker 3

Nectopsyche sp.

Polycentropus sp.

Potamyia flava (Hagen)

Triaenodes sp.

2 filterer

3 filterer

3 filterer

0 collector-gatherer

1

\section{3}

2

2 shredder/collector-gatherer filterer collector-gatherer filterer filterer shredder

\section{Lepidoptera}

Parapoynx sp.

3 shredder

Coleoptera

Ancyronyx variegatus (Germar) $2 \quad$ scraper

Oulimnius latiusculus (LeConte) $0 \quad$ scraper

- New records for UTRC 
POOL HABITAT TAXA

Diptera

Chironomidae

Conchapelopia sp.

Cryptochironomus sp.

4 predator

Macropelopia sp.

Microspectra sp.

Potthastia sp.

Stictochironomus sp.

3 predator

0 predator

2 collector-gatherer

1 scraper

2 collector-gatherer

Tabanidae

Tabanus sp.

3 predator

Ceratopogonidae

Bezzia/Palpomyia complex

3 predator

Oligochaeta

Tubificidae

4 scavenger

Odonata

Calopteryx sp.

3.5 predator

Ephemeroptera

Baetis sp.

Leptophlebia sp.

- Hexagenia limbata

Plecoptera

Leuctra sp.

2 shredder

Trichoptera

Molanna blenda

3 scraper

2 collector-gatherer

1 collector-gatherer

0 collector-gatherer

- A new record for UTRC 
SNAG HABITAT TAXA

Diptera

Chironomidae

Ablabesmyia sp.

Conchapelopia sp.

3 predator

Cricotopus / Orthocladius sp.

predator

Microspectra sp.

Microtendipes sp.

Paratendipes sp.

Polypedilum sp.

Rheotanytarsus sp.

Thienemanniella sp.

3 scraper

collector-gatherer

filterer

collecter-gatherer

collector-gatherer

3

filterer

collector-gatherer

Empididae

Hemerodromia sp.

4

predator

Simuliidae

Simulium sp.

2

filterer

Ceratopogonidae

Bezzia/Palpomyia complex

3

predator

Odonata

Calopteryx sp.

3.5

predator

Ephemeroptera

Acetrella ampla

Baetis sp.

Baetisca carolina

Ephemerella sp.

Plecoptera

Leuctra sp.

Perlesta placida

Beloneuria sp.

2

3

2

3

2

3

3

scraper

scraper

collector-gatherer

collector-gatherer

Trichoptera

Brachycentrus chelatus

Ceratopsyche sp.

Cheumatopsyche sp.

Chimarra sp.

Hydropsyche elissoma Ross

Hydropsyche decalda Ross

Lype diversa (Banks)

Macrostemum carolina (Banks)

$\begin{array}{ll}2 & \text { filterer } \\ 3 & \text { filterer } \\ 3 & \text { filterer } \\ 1 & \text { filterer } \\ 3 & \text { filterer } \\ 3 & \text { filterer } \\ 1 & \text { scraper } \\ 2 & \text { filterer }\end{array}$

shredder

predator

predator (assigned)

filterer 
Neureclipsis crepuscularis

Nectopsyche sp.

Nectopsyche candida (Hagen)

Nyctiophylax sp.

Oecetis inconspicua (Walker)

- Potamyia flava (Hagen)

Pycnopsyche scabripennis (rambur)

Triaenodes sp.

- Triaenodes tardus Milne

Coleoptera

Ancyronyx variegatus

Oulimnius latiusculus
3 filterer

2 scraper

0 scraper

- New records for UTRC 
Diptera

Chironomidae

Cladotanytarsus sp.

Clinotanypus sp.

Conchapelopia sp.

Corynoneura sp.

Cricotopus/Orthocladius sp.

Cryptochironomus sp.

Demicryptochironomus sp.

Guttipelopia sp.

Heterotrissocladius sp.

Microspectra sp.

Microtendipes sp.

Paracladopelma sp.

Parakiefferiella sp.

Paralauterborniella sp.

- Paramerina sp.

Parametriocnemus sp.

Polypedilum sp.

Potthastia longimanus (Kieffer

Procladius sp.

Rheocricotopus sp.

Rheotanytarsus sp.

Robackia sp.

Smittia sp.

Stempellina sp.

Stempellinella sp.

Synorthocladius sp.

Tanytarsus sp.

Thienemanniella sp.

Tribelos sp.

- Tretinia sp.

3

Tabanidae

Chrysops sp.

\section{Empididae}

Hemerodromia sp.

Ceratopogonidae

Bezzia/Palpomyia complex collector-gatherer

filter predator

predator

collector-gatherer scraper predator collector-gatherer predator collector-gatherer collector-gatherer filterer collector-gatherer collector-gatherer collector-gatherer predator collector-gatherer collector-gatherer scraper predator/collector collector-gatherer filterer predator collector-gatherer collector-gatherer collector-gatherer scraper collector-gatherer collector-gatherer collector-gatherer collector-gatherer

4. predator

3 predator 
Oligochaeta

Tubificidae

4 scavenger

Ephemeroptera

Attenella attenuata (mcDunnough) 0

Baetis ephippiatus Traver

collector-gatherer

scraper

scraper

Baetis intercalaris McDunnough 2

Baetis sp.

scraper

Caenis sp.

collector-gatherer

Cloeon sp.

collector-gatherer

collector-gatherer

Drunella tuberculata (Morgan)

scrapper

Plecoptera

Leuctra sp.

Perlesta placida

Beloneuria sp.

2 shredder

3 predator

3 predator (assigned)

Megaloptera

- Sialis americana (Rambur)

3 predator

Trichoptera

Agarodes sp.

Brachycentrus chelatus

Micrasema rusticum

Neureclipsis crepuscularis

Phylocentropus sp.

Polycentropus sp.

Oecetis inconspicua

Molanna blenda

shredder/collector-gatherer

filterer

shredder/collector-gatherer

filterer/shredder

filterer

predatorffilterer

predator

scraper/collector-gatherer

Coleoptera

Dineutus sp.

Optioservus sp.

3 scraper

3 scraper

Odonata

- Calopteryx angustipennis (Selys) 3.5 predator

Dromogomphus armatus Selys 2

- Dromogomphus spinosus Selys

Enallagma divagans Selys

2 predator

2 predator

3.5 predator

- New records for UTRC 


\section{LIST OF REFERENCES}

Allen, J.D. 1984. Hypothesis testing in ecological studies of aquatic insects. Pages 484-507 in V.H. Resh and D. M. Rosenberg (editors), Ecology of Aquatic Insects. Praeger Publishers, NY.

Anderson, N.H., J.R. Sedell, L.M. Roberts, and F.J.Triska. 1978. The role of aquatic invertebrates in processing of wood debris in coniferous forest streams. American Midland Naturalist 100: 64-82.

Anderson, N.H., R.J. Steedman, and T. Dudley. 1984. Patterns of exploitation by stream invertebrates of wood debris (xylophagy) Verh. Int. Ver. Theor. Limnol. 22:1847-1852.

Barmuta, L.A. 1989. Habitat patchiness and macrobenthic community structure in an upland stream in temperate Victoria, Australia. Freshwater Biology 21:223-236.

Barton, D.E. 1980. Benthic macroinvertebrate communities of the Athabasca River near Ft. Mackay, Alberta. Hydrobiologia 74:151-160.

Benke, A.C., T.C. Van Arsdall, Jr., D.M. Gillespie, and F.K. Parrish. 1984. Invertebrate productivity in a subtropical blackwater river: The importance of habitat and life history. Ecological Monographs 54: 25-63.

Bisson, P.A., R.E. Bilby, M.D. Bryant, C.A. Dolloff, G.B. Grette, R.A. House, M.L. Murphy, K.V. Koski, and J.R. Sedell. 1987. Large woody debris in forested streams in the Pacific Northwest: Past, present, and future. Pages 23-30 in T.R. Sedell (editor)Streamside management, forestry and fishery interactions. Institute of Forest Research, University of Washington, Seattle.

Brigham, A. R., W. U. Brigham and A. Gnilka. (editors), 1982. Aquatic insects and Oligochaetes of North and South Carolina. Midwest Aquatic Enterprises, Mahomet, IL. (837 pp).

Cattaneo, A., and J. Kalff. 1980. The relative contribution of aquatic macrophytes and their epiphytes to the production of macrophyte beds. Limnology and Oceanography 25:280-289.

Cole, G. A. 1983. Textbook of Limnology. The C. V. Mosby Company. St. Louis, $401 \mathrm{pp}$.

Colwell, R.K. 1974. Predictability, constancy, and contingency of periodic phenomena. Ecology 44:1148-1153. 
Cudney, M.D., and J.B. Wallace. 1980. Life cycles, microdistribution, and production dynamics of six species of net-spinning caddisflies in a large southeastern (U.S.A.) river. Holarctic Ecology 3:169-182.

Cummins, K.W. 1973. Trophic relations of aquatic insects. Annual Review of Entomology 18:183-206.

Cummins, K.W. 1977. From headwater streams to rivers. American Biology Teacher 39:305-312.

Cummins, K.W., and M. J. Klug. 1979. Feeding ecology of stream invertebrates. Annual Review of Ecology and Systematics 10:147-172.

Dudley, T., and N.H. Anderson. 1982. A survey of invertebrates associated with wood debris in aquatic habitats. Melangeria 39:1-21.

Gregg, W.W., and F.L. Rose 1985. Influence of aquatic macrophytes on invertebrate community structure, guild structure, and microdistribution in streams. Hydrobiologia 128:45-56.

Gurtz, M.E. 1984. Effects of disturbance regimes on stream biota. Pages 1-38 in B.J. Wallace and J. C. Webster (editors) Symposium on Long Term Research on Forested Watersheds at Coweeta. Athens, GA 15-16 October.

Gurtz, M.E., and J.B. Wallace 1984. Substrate-mediated response of stream invertebrates to disturbance. Ecology 65:1556-1569.

Hall, R.J., G. E. Likens, S. B. Fiance, and G. R. Hendrey. 1980.

Experimental acidification of a stream in the Hubbard Brook Experimental Forest, NH. Ecology 61:976-989.

Handoo, J.K., and V.Kaul. 1982. Standing crop and nutrient dynamics in Sparganium ramosum Huds. in Kashmir. Aquatic Botany 12:375-387.

Havas, M. 1981. Physiological response of aquatic animals to low $\mathrm{pH}$, Pages 49-65 in R. Singer (editor), Effects of Acid Precipitation on Benthos. North American Benthological Society, Springfield, IL. 154 Pp.

Headlee, T. J. 1941. The relative effects on metabolism to temperatures derived from constant and variable sources. Journal of Economic Entomology 33: 361-364.

Hilsenhoff, W.L. 1982. Using a biotic index to evaluate water quality in streams. Wisconsin Department of Natural Resources. Technical Bulletin 132. 
Huffaker, C. B. 1944. The temperature relations of the immature stages of the malarial mosquito, Anopheles quadrimaculatus Say, with a comparison of the developmental power of constant and variable temperatures in insect metabolism. Annals of the Entomological Society of America 37:1-27.

Huryn, A.D., and J. B. Wallace. 1988. Community structure of Trichoptera in a mountain stream: Spatial patterns of production and functional organization. Freshwater Biology 20: 141-155.

Hynes, H.B.N. 1970. The ecology of running waters. University of Toronto Press, Toronto. 555 pp.

Lamberti, G.A., and V.H. Resh. 1983. Stream periphyton and insect herbivores: An experimental study of grazing by a caddisfly population. Ecology 64: 1124-1135.

Langley, T.M., and W.L. Marter. 1973. The Savannah River Plant site. Savannah River Laboratory, Aiken, SC. DP-1323. 175 pp.

Lenat, D.R., L.A.Smock and D.L. Penrose. 1980. Use of benthic macroinvertebrates as indicators of environmental quality. Pages 97-112 in D.L. Wolf (editor), Biological Monitoring for Environmental Effects. Lexington Books, D.C. Heath and Co. Lexington, MA.

Lenat, D.R. 1988. Water quality assessment of streams using a qualitative collection method for benthic macroinvertebrates. Journal of the North American Benthological Society 7:222-233.

Leopold, A. 1933. Game Management. Charles Scribner's Sons, New York. 481 pp.

Leopold, L.B.,M.G. Wolman, and J.P. Miller. 1964. Fluvial processes in geomorphology. W.H. Freeman, San Francisco.

McElravy, E.P., G.A. Lamberti, and V.H. Resh 1989. Year-to-year variation in the aquatic macroinvertebrate fuana of a northern California stream. Journal of the North American Benthological Society. 8:51-63.

Mackay, R.J. 1977. Behavior of Pycnopsyche (Trichoptera; Limnephilidae) on mineral substrates in laboratory streams. Ecology 58: 191-195.

McGaha, Y.J. 1952. The limnological relations of insects to certain aquatic flowering plants. Transactions of the American Microscopic Society 71:335381. 
Mclntire, C.D. 1973. Periphyton dynamics in laboratory streams: simulation model and its implications. Ecological Monographs 43:399-420.

Merritt, R.W., and K.W. Cummins (editors). 1984. An Introduction to the Aquatic Insects of North America. 2nd Edition. Kondall / Hunt Publishing Co., New York, NY 722 pp.

Minshall, G.W. 1984, Aquatic insect-substratum relationships. Pages 358-400 in V.H. Resh and D. M. Rosenberg (editors). Ecology of Aquatic Insects. Praeger Publishers, New York.

Minshall, G.W. 1988. Stream Theory: A global perspective. Journal of the North American Benthological Society 7:263-288.

Minshall, G.W., and J.N. Minshall. 1977. Microdistribution of benthic invertebrates in a Rocky Mountain (U.S.A.) stream. Hydrobiologia 55:231-249.

Morse, J.C., J.W. Chapin, D.D. Herlong, and R.S. Harvey. 1980. Aquatic insects of Upper Three Runs Creek, Savannah River Plant, SC. Part I: Orders other than Diptera. Journal of the Georgia Entomological Society 15:73-101.

Morse, J.C., J.W. Chapin, D.D. Herlong, and R.S. Harvey. 1983. Aquatic insects of Upper Three Runs Creek, Savannah River Plant, SC. Part II: Diptera. Journal of the Georgia Entomological Society 18:303-316.

Morse, J. C., and B.W. Kelley. 1982. Aquatic Insects of Upper Three Runs Creek, SC. Paper presented at the 30th Annual Meeting of the North American Benthological Society. Ann Arbor, MI.

Morse, J. C., and W.R. English. 1984. Insect community characteristics of a blackwater stream in the South Carolina Sandhills. Paper presented at the 32nd Annual Meeting of the North American Benthological Society. Raleigh. NC.

Nebeker, A. V., and A. E. Lemke. 1968. Preliminary studies on the tolerance of aquatic insects to heated waters. Journal of the Kansas Entomological Society 41:413-418.

Otto, C., and B.S. Svensson. 1981. How do macrophytes growing in or close to water reduce their consumption by aquatic herbivores? Hydrobiologia 88: 107-112.

Peckarsky, B.L. 1984. Predator-prey interactions among aquatic insects. Pages 196-254 in V.H. Resh and D. M. Rosenberg (editors). Ecology of Aquatic Insects. Praeger Publishers, New York. 
Perkins, J.L. 1983. Bioassay evaluation of diversity and community comparison indices. Journal of the Water Pollution Control Federation 55:522-530.

Power, M.E., R.J. Stout, C.E. Cushing, P.P. Harper, F.R. Hauer, W.J. Matthews, P.B. Moyle, B. Statzner, and I.R. Wais De Bradgen. 1988. Biotic and abiotic controls in river and stream communities. Journal of the North American Benthological Society 7:456-479

Pringle, C.M., R.J. Naiman, G. Bretschko, J.R. Karr, M.W. Qswood, J.R. Webster, R.L. Welcomme, M.J. Winterbourn. 1988. Patch dynamics in lotic systems: The stream as a mosaic. Journal of the North American Benthological Society 7:503-524.

Rabeni, C.F. ,and G.W. Minshall. 1977. Factors affecting microdistribution of stream benthic insects. Oikos 29:33-43.

Reice, S.R. 1974. Environmental patchiness and the breakdown of leaf litter in a woodland stream. Ecology 55: 1271-1282.

Reice, S.R. 1985. Experimental disturbance and the maintenance of species diversity in a stream community. Oecologia 76:90-97.

Resh, V.H. 1979. Sampling variability and life history features: Basic considerations in the design of aquatic insect studies. Journal of the Fisheries Research Board of Canada 36:290-311.

Resh. V.H., A.V. Brown, A.P. Covich, M.E. Gurtz, H.W.Li, G.W. Minshall, S.R. Reice, A.L. Sheldon, J.B. Wallace, and R.C. Wissmar. 1988. The role of disturbance in stream ecology. Journal of the North American Benthological Society 7:433-455.

Resh, V.H. 1988. Variability, accuracy, and taxonomic costs of rapid assessment approaches in benthic biomonitoring. Pages 13-44 In Gore, J.A. and La Point, T.W. (editors), The role of benthos in impact assessment. North American Benthological Society Technical Information Workshop, Tuscaloosa, Alabama.

Sedell, J.R., F.H. Everest, and F.J. Swanson. 1982. Fish habitat and streamside management: past and present. Proceedings of the Society of American Foresters Annual Meeting. 1981:244-255.

Sheldon, A.L., and R.A. Haick. 1981. Habitat selection and association of stream insects: A multivariate analysis. Freshwater biology 11:395-403.

Smock, L.A., and D.A. Stoneburner. 1980. The response of aquatic macroinvertebrates to aquatic macrophyte decomposition. Oikos 35:397403. 
Smock, L.A., E.Gilinsky, and D.L. Stoneburner. 1985. Macroinvertebrate production in a southeastern U.S.A. blackwater stream. Ecology 66:14911503.

Smock, L.A., G.M. Metzler, J.E. Gladden. 1989. Role of debris dams in the structure and function of low-gradient headwater streams. Ecology 70:764775.

Soluk, D.A. 1985. Macroinvertebrate abundance and production of psammophilous Chironomidae in shifting sand areas of a lowland river. Canadian Journal of Fisheries and Aquatic Sciences 42:1296-1302.

Southwood, T.R.E. 1977. Habitat, the templet for ecological strategies? Journal of Animal Ecology 46:337-365.

Spence, D.H.N., and H.M. Dale. 1978. Variations in the shallow water form of Potamogeton richardsonii induced by some environmental factors. Freshwater Biology 8:251-268.

Statzner, B., and B. Higler. 1985. Questions and comments on the River Continuum Concept. Canadian Journal of Fisheries and Aquatic Sciences 42:1038-1044.

Statzner, B., J.A. Gore, and V.H. Resh 1988. Hydrolic stream ecology: observed patterns and potential applications. Journal of the North American Benthological Society. 7:307-360.

Strahler, A.N. 1957. Quantitative analysis of watershed geomorphology. Transactions of the American Geophysical Union 38:913-920.

Sweeney, B. W. 1984. Factors influencing life-history patterns of aquatic insects. .Pages 56-100 in V.H. Resh and D. M. Rosenberg (editors). Ecology of Aquatic Insects. Praeger Publishers, New York.

Sweeney, B. W., and R. L. Vannote. 1981. Ephemerella Mayflies of White Clay Creek: Bioenergetic and ecological relationships among six coexisting species. Ecology 62:1353-1369.

Titus. J.E., and M.S. Adams. 1979. Coexistence and the comparative light relations of submersed macrophytes Myriophyllum spicatum Michaux and Vallisneria americana Michaux. Oecologia 40:273-286.

Trotter. E.H. 1990. Woody debris, forest-stream succession, and catchment geomorpology. Journal of the North American Benthological Society 9:141156. 
Vannote, R. L. and B. W. Sweeney. 1980. Geographic analysis of thermal equilibrium: A conceptual model for evaluating the effect of the natural and modified thermal regimes on aquatic insect communities. The American Naturalist 115:667-695.

Vannote, R.L., G.W. Minshall, K.W. Cummins, J.F. Sedell and C.E. Cushing. 1980. The river continuum concept. Journal of Fisineries and Aquatic Science 37:130-137.

Wallace, J.B., and A.C. Benke. 1984. Quantfication of wood habitat in subtropical Coastal Plain streams. Canadian Journal of Fisheries and Aquatic Sciences 41:1643-1652.

Ward. J.V. 1967. Effects of flow patterns below large dams on stream benthos: a review. Pages 235-253 In J.F. Orsborn and C.H. Allman (editors), Instream Flow Needs, Vol.II. American Fisheries Society, Bethesda, Maryland. 657 PP.

Ward, J.V. 1975. Bottom fauna-substrate relationships in a Northern Colorado trout stream: 1945 and 1974. Ecology 56: 1429-1434.

Wiederholm, T. 1984. Response of aquatic insects to environmental pollution. Pages 508-557 in V.H. Resh and D. M. Rosenberg (editors). Ecology of Aquatic Insects. Praeger Publishers, New York.

Williams, D.D. 1984. The hyporheic zone as a habitat for aquatic insects and associated arthropods. Pages 430-454 in V.H. Resh and D. M. Rosenberg (editors). Ecology of Aquatic Insects. Praeger Publishers, New York.

Wilhm, J. L. 1970. Range of diversity index in benthic macroinvertebrate populations. Journal of Water Pollution Control Federation 42:221-224.

Wilhm, J. and Dorris, T. C. 1968. Biological parameters for water quality criteria. Bioscience. 18:477-449.

Zar, J.H. 1974. Biostatistical analysis. Prentice-Hall, Inc., Englwood Cliffs, N.J. $620 \mathrm{pp}$. 
This report was prepared by Westinghouse Savannah River Company for the U.S. Depertment of Energy under Contract Numbers DE-AC09-76SR00001 and DE-AC09-89SR18035 and is an account of work performed under that contract. Every effort was made by the authors to asaure the accuracy of the contents and interpretation. However, neither the United States Department of Energy, nor WSRC, nor any of their employees makes any apecific warranty, expressed or implied, or assume legal liability for the completeness or usefulness of the information disclosed herein. The views and opinions of the authors expressed herein do not necessarily state or reflect those of the United States Government or any arency thereof. 


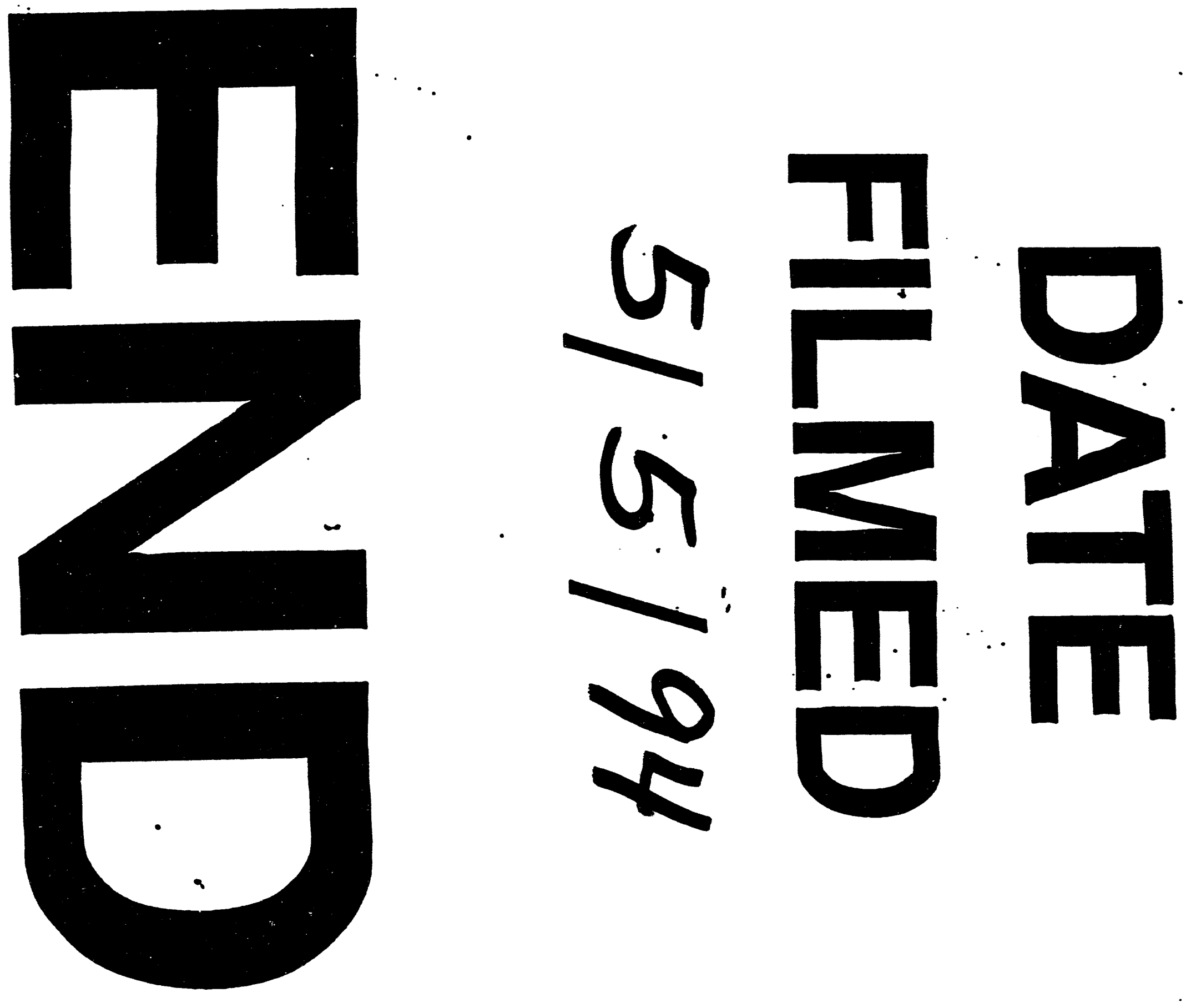


